Nevada

DOE/ N V -4 83 -REV 1

Environmental

Restoration

Project

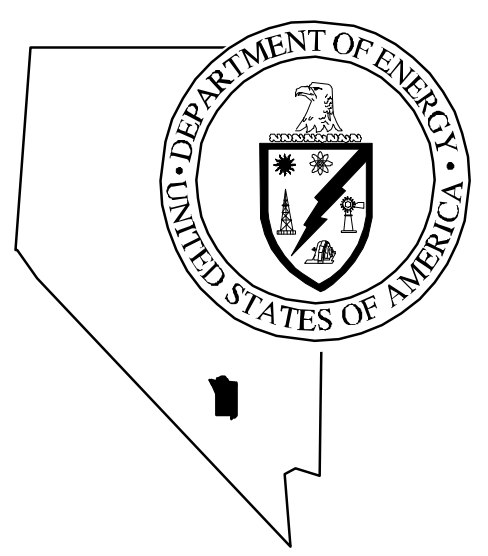

Corrective Action Investigation Plan

for the Central $N$ evada Test Area

Subsurface $S$ ites

(Corrective Action Unit N 0.443 )

Controlled Copy N $0 .:$

Revision N 0.: 1

February 1999

Approved for public release; further dissemination unlimited.

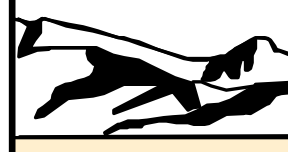

Environm ental Restoration

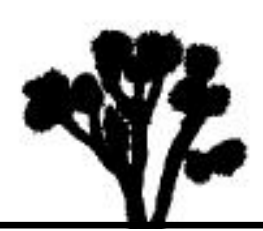

Division 
Available to the public from -

U.S. Department of Commerce

National Technical Information Service

5285 Port Royal Road

Springfield, VA 22161

(703) $487-4650$

Available electronically at http://www.doe.gov/bridge. Available to U.S. Department of Energy and its contractors in paper from -

U.S. Department of Energy

Office of Scientific and Technical Information

P.O. Box 62

Oak Ridge, TN 37831-0062

(423) $576-8401$ 


\title{
CORRECTIVE ACTION INVESTIGATION PLAN FOR THE CENTRAL NEVADA TEST AREA SUBSURFACE SITES (CORRECTIVE ACTION UNIT NO. 443)
}

\author{
DOE Nevada Operations Office \\ Las Vegas, Nevada
}

Controlled Copy No.:

Revision: 1

February 1999

Approved for public release; further dissemination unlimited. 


\section{CORRECTIVE ACTION INVESTIGATION PLAN \\ FOR THE CENTRAL NEVADA TEST AREA \\ SUBSURFACE SITES \\ (CORRECTIVE ACTION UNIT NO. 443)}

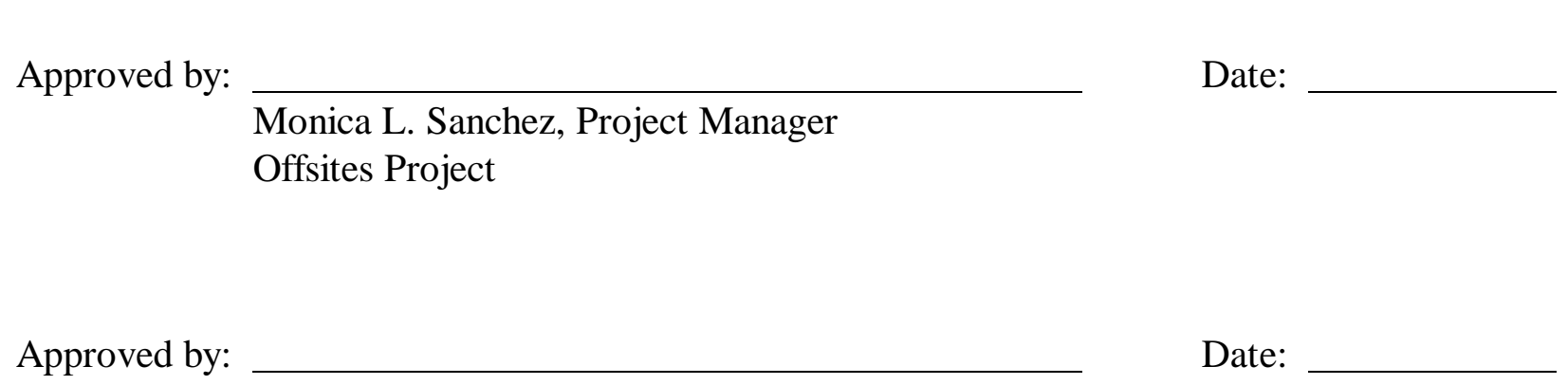

Runore C. Wycoff, Division Director

Environmental Restoration Division 


\section{Table of Contents}

List of Figures $\ldots \ldots \ldots \ldots \ldots \ldots \ldots \ldots \ldots \ldots \ldots \ldots \ldots \ldots \ldots \ldots \ldots \ldots \ldots$

List of Tables $\ldots \ldots \ldots \ldots \ldots \ldots \ldots \ldots \ldots \ldots \ldots \ldots \ldots \ldots \ldots \ldots \ldots \ldots \ldots \ldots$

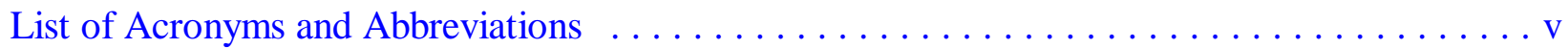

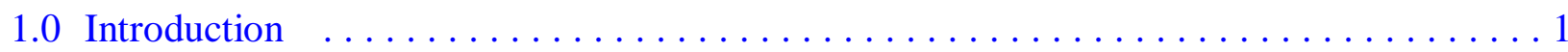

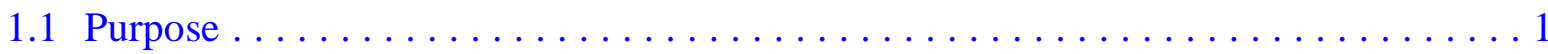

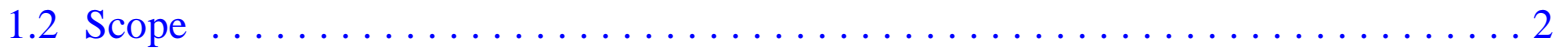

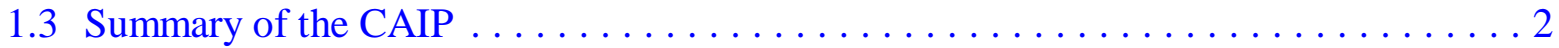

2.0 Legal/Regulatory Requirements $\ldots \ldots \ldots \ldots \ldots \ldots \ldots \ldots \ldots \ldots \ldots \ldots$

2.1 FFACO Requirements $\ldots \ldots \ldots \ldots \ldots \ldots \ldots \ldots \ldots \ldots \ldots \ldots \ldots \ldots \ldots \ldots$

2.1 .1 General Requirements $\ldots \ldots \ldots \ldots \ldots \ldots \ldots \ldots \ldots \ldots \ldots \ldots \ldots$

2.1.2 Specific Requirements . . . . . . . . . . . . . . . . . 4

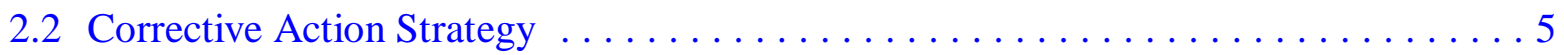

3.0 Description of Corrective Action Unit $\ldots \ldots \ldots \ldots \ldots \ldots \ldots \ldots \ldots \ldots \ldots \ldots \ldots \ldots \ldots$

3.1 Investigative Background $\ldots \ldots \ldots \ldots \ldots \ldots \ldots \ldots \ldots \ldots \ldots \ldots \ldots \ldots \ldots \ldots \ldots \ldots$

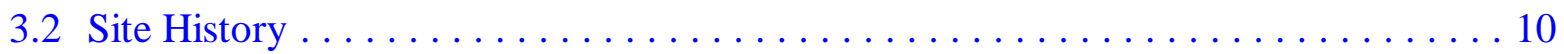

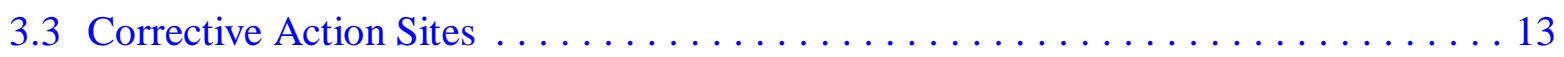

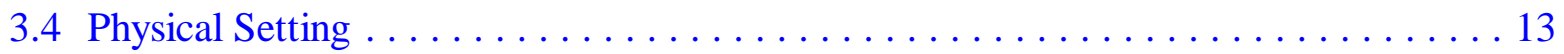

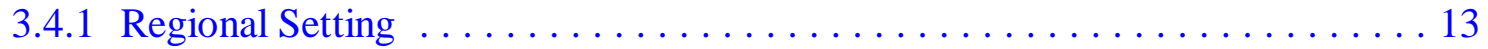

3.4 .2 Local Setting . . . . . . . . . . . . . . . . . . . 17

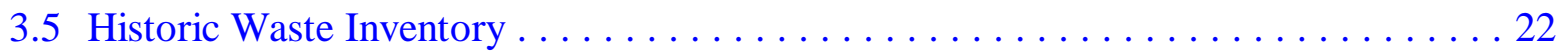

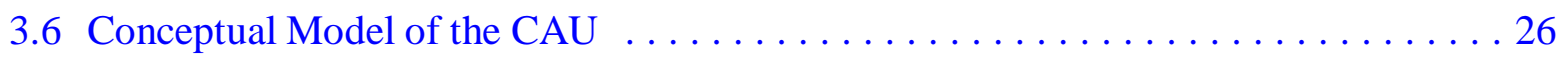

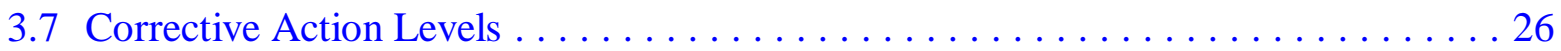

4.0 Summary of Data Quality Objectives, Processes and Results . . . . . . . . . . . . 28

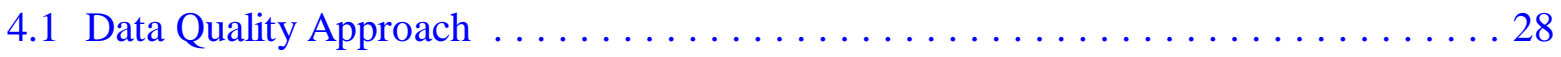

4.2 Data Quality Objectives Process Results for UC $-1 \ldots \ldots \ldots \ldots \ldots$

4.3 Data Quality Objectives Process Results for UC-4 . . . . . . . . . . . . . . . . . . . 29 


\section{Table of Contents (Continued)}

5.0 Corrective Action Investigation $\ldots \ldots \ldots \ldots \ldots \ldots \ldots \ldots \ldots \ldots \ldots \ldots \ldots \ldots \ldots \ldots$

5.1 Analytic/Numerical Model(s) Applied to CAU Data . . . . . . . . . . . . 31

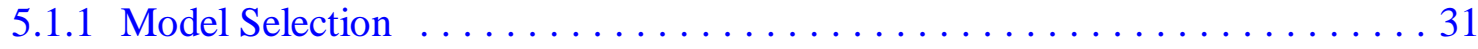

5.1.2 Model Discussion/Documentation/Data Availability . . . . . . . . . . 32

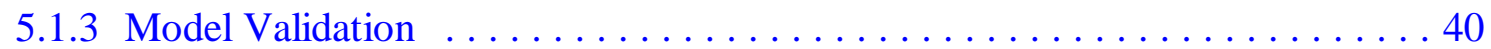

5.1.3.1 Model Purpose and Objectives . . . . . . . . . . . . 41

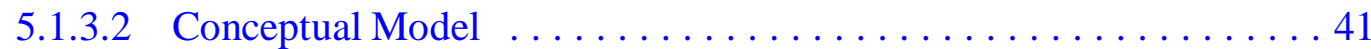

5.1.3.3 Selection of a Computer Code and Code Verification . . . . . . . . 41

5.1.3.4 Model Design . . . . . . . . . . . . . . . . . . . 42

5.1.3.5 Model Calibration . . . . . . . . . . . . . . . . . . . . . . . 42

5.1.3.6 Sensitivity and Uncertainty Analyses . . . . . . . . . . . . . 42

5.1.3.7 Model Review . . . . . . . . . . . . . . . . . . . . . 43

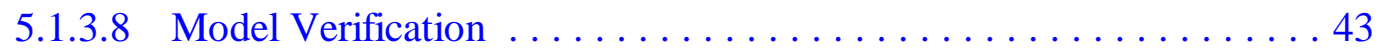

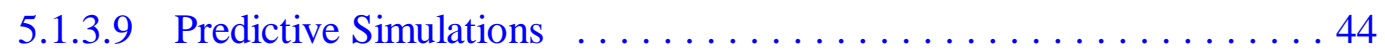

5.1.3.10 Presentation of Model Results $\ldots \ldots \ldots \ldots \ldots \ldots \ldots$

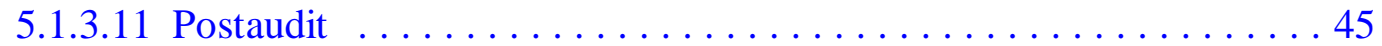

5.1 .4 Define Contaminant Boundaries $\ldots \ldots \ldots \ldots \ldots \ldots \ldots \ldots \ldots \ldots \ldots \ldots \ldots \ldots \ldots$

6.0 Field Investigation/No Field Investigation $\ldots \ldots \ldots \ldots \ldots \ldots \ldots \ldots \ldots$

6.1 Topical Areas of Field Investigation $\ldots \ldots \ldots \ldots \ldots \ldots \ldots \ldots \ldots \ldots \ldots \ldots \ldots \ldots$

6.2 No Field Investigation $\ldots \ldots \ldots \ldots \ldots \ldots \ldots \ldots \ldots \ldots \ldots \ldots \ldots$

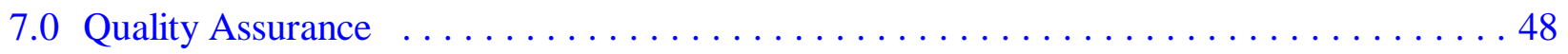

8.0 Duration and Records/Data Availability . . . . . . . . . . . . . . . . . . . . . 49

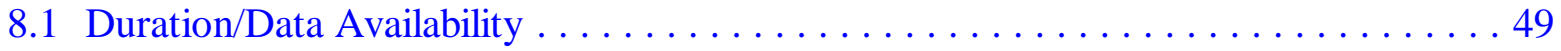

8.2 Document/Records Availability . . . . . . . . . . . . . . . . . . 49

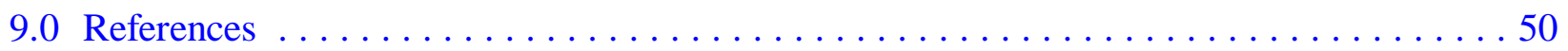

Appendix A - Data Quality Objectives Worksheets . . . . . . . . . . . . . . . 57

Appendix B - NDEP Comment Review Sheets . . . . . . . . . . . . . . . 70 


\section{List of Figures}

Number

1-1 Process Flow Diagram for Underground Test Area Corrective Action Units . . . . . 3

2-1 Example of Contaminant Boundary Confidence Levels . . . . . . . . . . . . 6

3-1 Boring and Well Locations, Central Nevada Test Area . . . . . . . . . . . . . . 12

3-2 Cross Section Across Hot Creek Valley $\ldots \ldots \ldots \ldots \ldots \ldots \ldots \ldots \ldots$

3-3 Water Level Contours in Hot Creek Valley . . . . . . . . . . . . . 16

3-4 Location of Wells Near the Faultless Site . . . . . . . . . . . . . . . . . . 19

3-5 Water Elevations in HTH-1 and HTH-2 from 1968 to $1997 \ldots \ldots \ldots$

3-6 Typical Water-Table Response to Detonation in the Saturated Zone at Yucca Flat, Nevada Test Site . . . . . . . . . . . . . . . . . . . 21

5-1 Wells Near DOE Land Withdrawals in Northern Hot Creek Valley . . . . . . . . . 33 


\section{List of Tables}

Number

3-1 Central Nevada Test Area Subsurface Corrective Action Sites . . . . . . . . . . . . . . 14

3-2 Analytical Data from the 1986 REECo Survey $\ldots \ldots \ldots \ldots \ldots \ldots \ldots \ldots \ldots$

3-3 Central Mud Pit and UC-4 Mud Pit 1995 Analytical Results . . . . . . . . . . . . 25 


\section{List of Acronyms and Abbreviations}

AEC

Am

$\mathrm{Ar}$

ASTM

$\mathrm{C}$

$\mathrm{Ca}$

CADD

CAI

CAIP

CAS

CAU

$\mathrm{Cl}$

$\mathrm{Cm}$

CNTA

Co

Cs

DOE

DOE/NV

DQO

DRI

$\mathrm{Eu}$

FFACO

$\mathrm{ft}$

$\mathrm{ft}^{2}$

$\mathrm{H}$

I

in.

IT

$\mathrm{K}$

$\mathrm{k}_{\mathrm{d}}$

$\mathrm{kg}$

$\mathrm{km}$

$\mathrm{km}^{2}$
U.S. Atomic Energy Commission

Americium

Argon

American Society for Testing and Materials

Carbon

Calcium

Corrective Action Decision Document

Corrective Action Investigation

Corrective Action Investigation Plan

Corrective Action Site

Corrective Action Unit

Chlorine

Curium

Central Nevada Test Area

Cobalt

Cesium

U.S. Department of Energy

U.S. Department of Energy, Nevada Operations Office

Data quality objective

Desert Research Institute

Europium

Federal Facility Agreement Consent Order

Foot (feet)

Square foot (feet)

Hydrogen

Iodine

Inch(es)

IT Corporation

Hydraulic conductivity

Distribution coefficient

Kilogram(s)

Kilometer(s)

Square kilometer(s) 


\section{List of Acronyms and Abbreviations (Continued)}

\begin{tabular}{|c|c|}
\hline $\mathrm{Kr}$ & Krypton \\
\hline $\mathrm{m}$ & Meter(s) \\
\hline $\mathrm{mg} / \mathrm{kg}$ & Milligram(s) per kilogram \\
\hline $\mathrm{mg} / \mathrm{L}$ & Milligram(s) per liter \\
\hline $\mathrm{m} / \mathrm{d}$ & Meter(s) per day \\
\hline$\mu \mathrm{g} / \mathrm{kg}$ & Microgram(s) per kilogram \\
\hline $\mathrm{mi}$ & Mile(s) \\
\hline $\mathrm{mi}^{2}$ & Square mile(s) \\
\hline $\mathrm{m} / \mathrm{yr}$ & Meter(s) per year \\
\hline $\mathrm{mrem} / \mathrm{yr}$ & Millirem(s) per year \\
\hline $\mathrm{Na}$ & Sodium \\
\hline NDEP & Nevada Department of Environmental Protection \\
\hline $\mathrm{Ni}$ & Nickel \\
\hline NTS & Nevada Test Site \\
\hline $\mathrm{pCi}$ & Picocurie(s) \\
\hline $\mathrm{pCi} / \mathrm{L}$ & Picocurie(s) per liter \\
\hline pdf & Probability distribution factor \\
\hline $\mathrm{Pm}$ & Promethium \\
\hline PTRW & Particle-tracking random walk simulation method \\
\hline $\mathrm{Pu}$ & Plutonium \\
\hline REECo & Reynolds Electrical and Engineering Company, Inc. \\
\hline $\mathrm{Sb}$ & Antimony \\
\hline $\mathrm{Sm}$ & Samarium \\
\hline $\mathrm{Sn}$ & Tin \\
\hline $\mathrm{Sr}$ & Stontium \\
\hline Tc & Technetium \\
\hline TCLP & Toxicity Characteristic Leaching Procedure \\
\hline $\mathrm{U}$ & Uranium \\
\hline UGTA & Underground Test Area \\
\hline
\end{tabular}




\subsection{Introduction}

This Corrective Action Investigation Plan (CAIP) describes the U.S. Department of Energy's (DOE's) planned environmental investigation of the subsurface Central Nevada Test Area (CNTA) Corrective Action Unit (CAU) No. 443. The CNTA is located in Hot Creek Valley in Nye County, Nevada, adjacent to U.S. Highway 6, about 48 kilometers (km) (30 miles [mi]) north of Warm Springs, Nevada. The CNTA was the site of Project Faultless, a nuclear device detonated in the subsurface by the U.S. Atomic Energy Commission (AEC) in January 1968. The purposes of this test were to gauge the seismic effects of a relatively large, high-yield detonation completed in Hot Creek Valley (outside the Nevada Test Site) and to determine the suitability of the site for future large detonations. The yield of the Faultless test was between 200 kilotons and 1 megaton. Two similar tests were planned for the CNTA, but neither of them was completed (AEC, 1974).

\subsection{Purpose}

Based on the general definition of a corrective action investigation (CAI) from Section IV.14 of the Federal Facility Agreement and Consent Order (FFACO), the purpose of the CAI is "...to gather data sufficient to characterize the nature, extent, and rate of migration or potential rate of migration from releases or discharges of pollutants or contaminants and/or potential releases or discharges from corrective action units identified at the facilities..." (FFACO, 1996). For CNTA CAU 443 the concepts developed for the Underground Test Area (UGTA) CAUs will be applied on a limited scale. For the UGTA CAUs, "...the objective of the CAI process is to define boundaries around each UGTA CAU that establish areas that contain water that may be unsafe for domestic and municipal use," as stated in Appendix VI of the FFACO (1996). Based on this strategy the CAI for CAU 443 will start with modeling using existing data. New data collection activities are generally contingent upon the results of the modeling and may or may not be part of the CAI.

Specific objectives of the CAI are as follows:

- Determine the characteristics of the groundwater flow system, the sources of contamination, and the transport processes to acceptable levels of uncertainty.

- Develop a credible numerical model of groundwater flow and contaminant transport for the UC-1 Subsurface Corrective Action Site (CAS) and downgradient areas.

- Develop stochastic predictions of the contaminant boundary at an acceptable level of uncertainty. 


\subsection{Scope}

A three-dimensional flow and transport model will be constructed for the Central Nevada Test Area subsurface. The model will be developed to locate an acceptable contaminant boundary within which water use restrictions will be implemented to prevent exposure to potentially contaminated groundwater. Existing information will be used to provide input parameters to the flow and transport modeling.

In the first major decision point for the CNTA Subsurface Corrective Action Investigation, a determination will be made as to whether the modeling results are acceptable (Figure 1-1). The shaded portion of the diagram illustrates the portion of the process that will take place during the Corrective Action Investigation. If the modeling results are accepted, then a boundary will be established, and the results will be presented to the Nevada Department of Environmental Protection (NDEP). If the modeling results are not accepted the strategy will be reevaluated to determine if it is achievable. If the strategy is not achievable a new strategy will be proposed and discussed with the NDEP. If the strategy is achievable an analysis will be performed to determine what data are needed to achieve acceptable modeling results. If, after the acquisition of new data is complete and the data have been incorporated in the model, the DOE accepts the modeling results, a boundary will be established, and the results will be presented to the NDEP. If the NDEP agrees to the boundary, a Corrective Action Decision Document (CADD) will be prepared.

\subsection{Summary of the CAIP}

Section 1.0 introduces the purpose and scope of the CAIP. Section 2.0 states the legal/regulatory requirements. Section 3.0 describes the investigative background and site history, lists the CASs, and discusses the physical setting and historic waste inventory. Section 3.0 also contains a conceptual model of the CAU and covers the Corrective Action levels. The Data Quality Objectives (DQOs) process is summarized in Section 4.0, and Appendix A presents the DQO worksheets. Section 5.0, which describes the Corrective Action Investigation, details the modeling approach, including model selection, model attributes, data availability, model validation, the definition of contaminant boundaries, and determination of model acceptability. Section 6.0 discusses the topic of field investigation, Section 7.0 is quality assurance, and Section 8.0 covers the availability of data and other records. Section 9.0 is a reference list. 


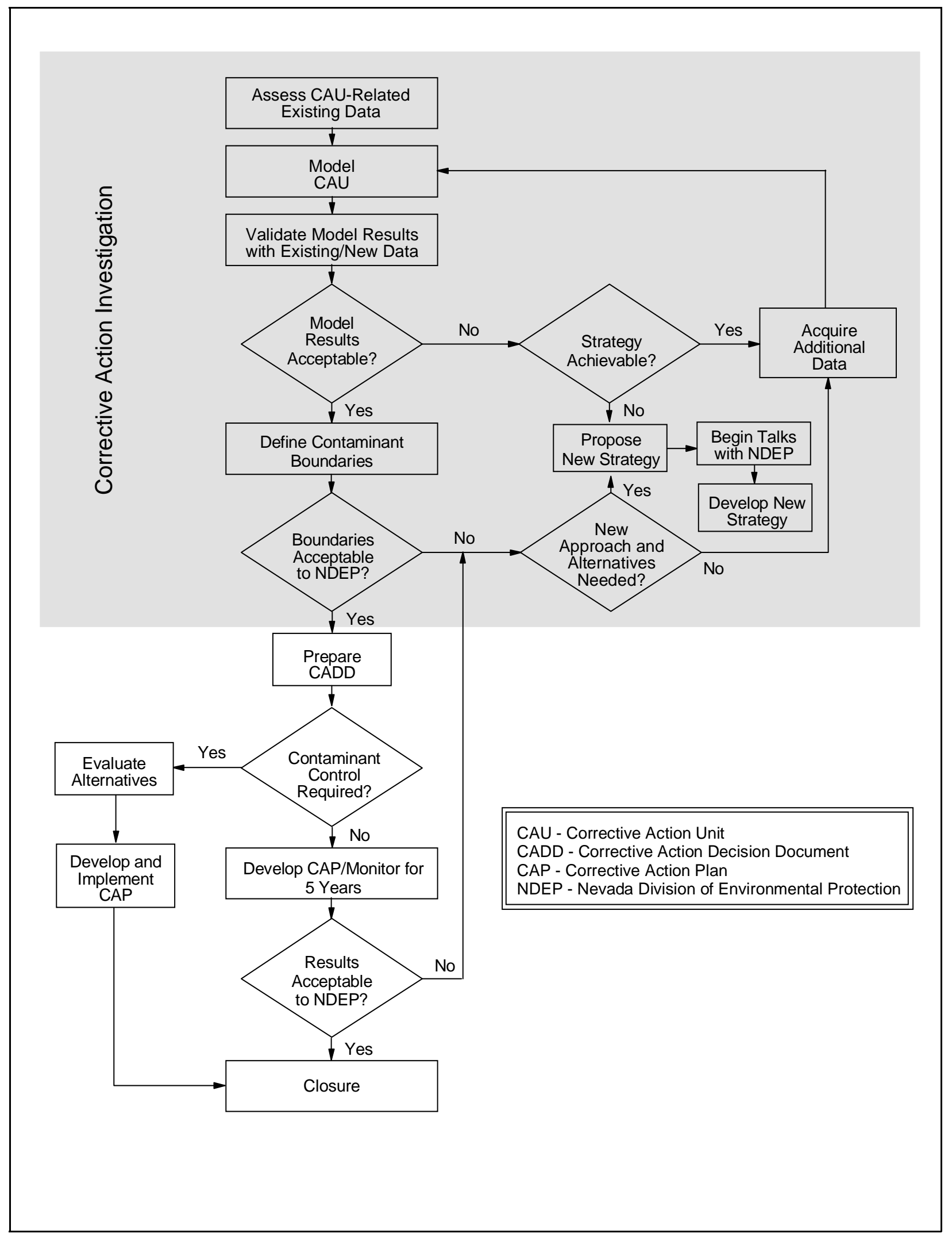




\subsection{Legal/Regulatory Requirements}

The DOE, DoD, and the Nevada Division of Environmental Protection (NDEP) have negotiated a Federal Facility Agreement and Consent Order to address environmental restoration activities at U.S. Department of Energy, Nevada Operations Office (DOE/NV) facilities and sites. The FFACO is the primary regulatory driver for DOE environmental restoration activities in the State of Nevada. The FFACO regulatory requirements applicable to the CNTA Subsurface Corrective Action Investigation (CAI) are discussed in this section.

\subsection{FFACO Requirements}

The FFACO requirements that are applicable to CNTA subsurface are discussed in this section.

\subsubsection{General Requirements}

The FFACO sets the framework and contains the regulations for prioritizing and enforcing the environmental restoration activities of potentially contaminated DOE/NV sites. In addition, the FFACO provides technical strategies for the completion of these activities. The DOE, through the Off-Sites Project, is responsible for completing corrective actions for two CAUs associated with underground nuclear testing off the Nevada Test Site (NTS) but within the State of Nevada. This CAI guides the investigation activities for one of the CAUs at the CNTA.

\subsubsection{Specific Requirements}

The CNTA subsurface corrective action investigation will be planned and conducted in accordance with the appropriate investigation purposes of the FFACO as outlined in Paragraphs II.1.b.ii, II.1.c as well as the requirements of Paragraphs IV.14, and IV.15 (FFACO, 1996). A description of how the investigation requirements are being fulfilled during the CAI is provided below.

\section{Paragraph II.a.b.ii}

In accordance with this Paragraph of the FFACO, groundwater flow and transport models designed to determine whether releases are migrating or could potentially migrate, have been conducted and/or are planned in the CAI as described in Sections 5.0 and 6.0. Also, in accordance with this Paragraph, a preliminary list of the potential constituents of concern and their concentrations is provided in Section 3.5. A description of the nature and extent of the contaminant migration based on the current information is presented in Sections 3.4 and in 3.6 of this report. This description will be updated based on the findings of the CAI. 


\section{Paragraph II.1.c}

As required by this Paragraph, a preliminary list of radioactive and hazardous constituents for the CNTA Subsurface Corrective Action Unit is specified in Section 3.5 of this report. This list is established to provide all parties with sufficient information to enable adequate evaluation of appropriate remedies. The list will be updated based on the findings made during the CAI.

\section{Paragraph IV.14}

In accordance with this Paragraph, the CNTA Subsurface Corrective Action Investigation will be conducted by DOE to gather sufficient data to characterize the nature, extent, and rate of migration or potential rate of migration from releases or potential releases of contaminants from the CNTA Subsurface Corrective Action Unit. This CAIP describes the planned investigation activities which are limited to fate and transport modeling (Section 5.0). There are no field activities planned at this time (Section 6.0).

\section{Paragraph IV.15}

In accordance with Paragraph IV.15, this CAIP provides or references all of the specific information for planning investigation activities associated with the CNTA Subsurface Corrective Action Units. This CAIP includes or references all of the management, technical, quality assurance, health and safety, public involvement, field sampling, and waste management information needed to conduct the investigations in compliance with established procedures and protocols as described in Section 1.0.

All information provided in this CAIP is based on the current state of knowledge and will be updated following completion of the CAI. The results will be reported in the CADD.

\subsection{Corrective Action Strategy}

The objectives of the Off-Site strategy are to predict the location of the contaminant boundary for each CAU, develop and implement a corrective action, and close each CAU.

Uncertainties will be associated with the contaminant boundary predictions using the CAU models (FFACO, 1996). These uncertainties can be expressed as confidence levels as shown on Figure 2-1.

The distance from the source of contamination (the CAU in Figure 2-1) to the contaminant boundary increases as the confidence level increases. 


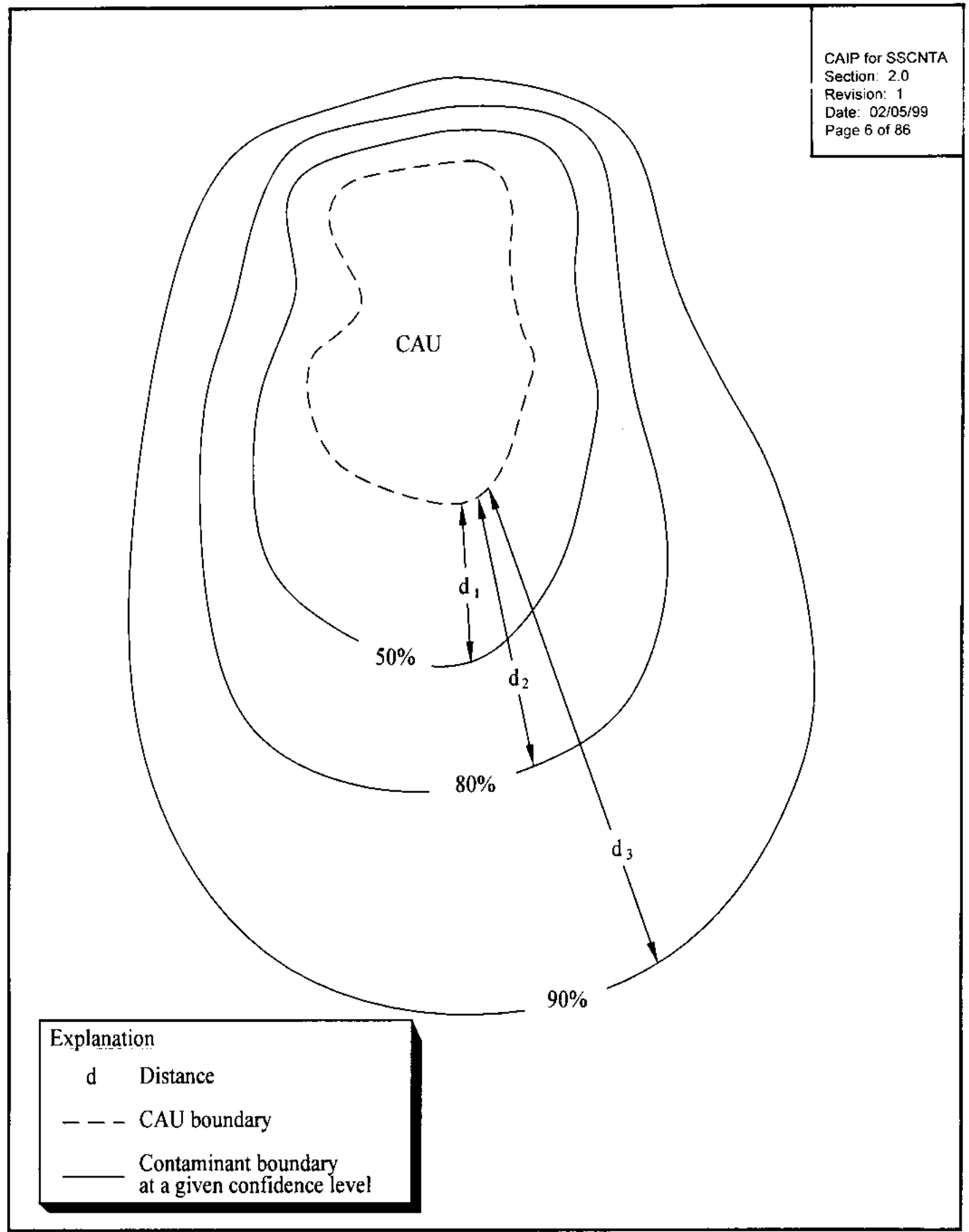

Figure 2-1

Example of Contaminant Boundary Confidence Levels 
The process to achieve the strategy is defined in the flow diagram on page VI-3-6 of FFACO Appendix VI (Figure 1-1).

The first step of the strategy will be the modeling effort. As provided for in the FFACO, if the model is acceptable, a contaminant boundary will be proposed for concurrence with the state. However, if the model results are determined to be unacceptable or the contaminant boundary cannot be agreed upon between DOE and NDEP, then DOE and NDEP will determine if the strategy is achievable. If the strategy can be achieved, DOE will propose work scope to collect additional data. The new data will then be used in the CAU model and the evaluation process will be repeated. After the contaminant boundaries have been defined and accepted, DOE will evaluate various remedial alternatives and propose a corrective action. 


\subsection{Description of Corrective Action Unit}

\subsection{Investigative Background}

Investigations of the geology and hydrogeology of the CNTA and surrounding region have taken place from the late 1960s to the present, encompassing geologic mapping, geophysical logging, analysis of water chemistry (including major ions, metals, and both stable and radioactive isotopes), and hydraulic testing. Site investigation activities associated with CNTA have been identified and documented in the Final Environmental Impact Statement for the Nevada Test Site and Off-Site Locations in the State of Nevada (DOE, 1996a).

Geologic maps of the area have been produced by Anderson et al. (1967), Ekren et al. (1968; 1970; 1973a; 1973b), and Quinlivan and Rogers (1974). Overviews of regional geology are provided by Fiero et al. (no date) and Rush and Everett (1966). Site-specific stratigraphy based on drill cores and cuttings is discussed by Hoover (1968) and Thordarson (1987). McKeown et al. (1968) examine the geologic phenomena resulting from the detonation, a topic also touched on by Dinwiddie and West (1970). Geophysical logs, cores, and cuttings from over 20 wells in central Nevada are available for study at the U.S. Geological Survey Core Library in Mercury, Nevada (Magner, 1996).

Hydraulic test results are given by Dinwiddie (1968; 1969a; 1969b; 1970a; 1970b; 1970c; 1970d), Dinwiddie and Schroder (1971), and Thordarson (1987). Potentiometric surface data were provided by Dinwiddie (1972), Dinwiddie and Schroder (1971), Dinwiddie and West (1970), Fiero et al. (no date), Fiero and Illian (1969), Rush and Everett (1966), and Thordarson (1985; 1987), with Dinwiddie (1972), Dinwiddie and West (1970), and Thordarson (1985; 1987) focusing on post-detonation changes to water levels in the area.

Regional flow systems are described by Dinwiddie and Schroder (1971), Fiero et al. (no date), Fiero and Illian (1969), two studies by Fiero et al. (1974; no date), and Rush and Everett (1966). Hydraulic head relationships in the CNTA flow model will be based on head measurements in exploratory wells constructed for the CNTA siting investigations and the U.S. Air Force's MX exploration program, and several water supply wells in Hot Creek and surrounding valleys. The CNTA dataset includes depth-discrete head measurements made in straddle-packed intervals in ten of the boreholes (Dinwiddie and Schroder, 1971). Four of these boreholes are located within or adjacent to the CNTA UC-1, UC-3, and UC-4 land withdrawals. Most of these values were measured in the mid-1960s while some, particularly several local supply wells, have measurement 
dates in the 1950s and even 1940s (Rush and Everett, 1966). The Hot Creek Valley hydrologic system is large and has not been subject to excessive withdrawals (1,890 acre- feet per year were committed out of a perennial yield of 5,500 as of 1988; [Nevada, State of, 1988]) such that significant fluctuations in regional water levels are not expected through time. Despite the probable steady-state conditions, confirmation of current regional water levels was considered desirable to allow greater certainty to be placed on the head values used for the modeling. Water levels were determined from available wells in Hot Creek Valley, the northern portion of Reveille Valley, and the southern portion of Big Sand Springs Valley between August 11, 1997, and August 17, 1997. A total of 34 wells were investigated, four of which were dry and 10 of which did not have access for measuring equipment. The potentiometric map produced using those data is consistent with the previous one, describing groundwater flow basically down the valley axis, from north to south. Local hydrologic conditions at CNTA have been monitored for many years and reveal a complex near-field system affected by the nuclear test (Thordarson, 1985 and 1987; Chapman et al., 1994; Davisson et al., 1994; Mihevc et al., 1996). Recent hydrologic logging and sampling have continued with a data collection effort between October 20 and 26, 1997.

Water chemistry data are provided by Buddemeier et al. (1985), Chapman et al. (1994), Davisson et al. (1994), Dinwiddie (1972), Dinwiddie and West (1970), Dinwiddie and Schroder (1971), Fiero et al. (1974), Mihevc et al. (1996), Nork et al. (1971), Rush and Everett (1966), Schroder et al. (1971), and Thordarson (1985; 1987).

Nork et al. (1971) supply distribution coefficients $\left(\mathrm{k}_{\mathrm{d}}\right)$ values for calcium-45 $\left({ }^{45} \mathrm{Ca}\right),{ }^{85} \mathrm{Sr}$, and ${ }^{137} \mathrm{Cs}$ determined from laboratory studies using rock samples from drill holes in Hot Creek Valley. Additional sorption experiments are currently underway using CNTA cores previously stored at the U.S. Geological Survey Core Library in Mercury, Nevada. The study will generate the geochemical parameters describing equilibrium partitioning of radionuclides and contaminants of concern between the aqueous phase and aquifer material. The mineralogic composition of the rocks has been determined. Experiments are being conducted with both cations and anions. Strongly and weakly binding cations and anions are used to establish sorption parameters corresponding to limiting transport scenarios. Lead and strontium cations are used as strongly and weakly binding cation analogs, respectively. Selenite and chromate anions will be used as strongly and weakly binding anion analogs, respectively. 
Site demobilization activities are described by the AEC $(1973$; 1974) and Eberline Instrument Corporation (1973).

Two analyses of the human health risk caused by migration of contaminants in groundwater from the Faultless cavity have been performed. Pohlmann et al. (1995) modeled potential migration of tritium away from the cavity and evaluated the risk due to tritium to an individual consuming groundwater for a lifetime centered around the peak tritium concentration as part of the Environmental Impact Statement for DOE activities in Nevada. Johnson et al. (1996) employed the same scenario and transport parameters identified by Pohlmann et al. (1995), but used a nuclear reactor computer code to calculate the source term. In addition, they considered risk due to cesium and strontium, but found that the risk due to these two contaminants is effectively zero.

The U.S. Environmental Protection Agency, which monitors groundwater around CNTA annually as part of the Long Term Hydrologic Monitoring Program, has consistently found tritium concentrations below the minimum detectable concentration (approximately seven to ten picocuries per liter $[\mathrm{pCi} / \mathrm{L}])$. They conclude that, to date, migration into the sampled wells has not taken place and that no event-related radioactivity has entered area drinking water supplies (Chaloud et al., 1992).

\subsection{Site History}

In November 1966 a search was initiated to identify a secondary test site to supplement the Nevada Test Site. Eight areas in central Nevada and several areas outside of Nevada were considered. In January 1967 the site selection committee identified several priority areas for deep geologic exploration. The Central Nevada Test Area located in North Hot Creek Valley was one of the sites selected. In lieu of forming one, large test site, the CNTA was made up of approximately 20 separate properties obtained from the BLM through land withdrawals, land easements, and special land-use permits. Consequently, construction of surface facilities and the drilling of an emplacement hole for Project Faultless was begun. The first test conducted in the CNTA, Project Faultless, was a calibration experiment to gage the suitability of the area for larger underground tests.

The Faultless device emplacement boring (UC-1) was drilled on a 2.59-square-kilometer $\left(\mathrm{km}^{2}\right)$ (one-square-mile $\left[\mathrm{mi}^{2}\right]$ ) land withdrawal which was formalized between the AEC and U.S. Bureau of Land Management on December 6, 1967, under Public Land Order \#4338. In addition to the 
three emplacement borings completed at CNTA, several other boreholes were completed for preshot and post-shot hydrologic and geologic investigations (Figure 3-1).

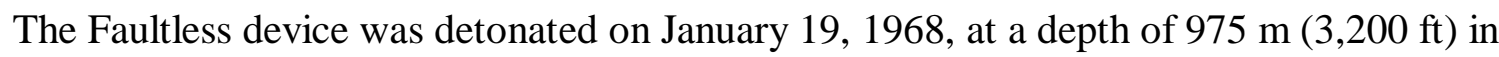
emplacement boring UC-1. The resulting shot cavity occurs in the volcanic unit at the working point and extends into the overlying surficial alluvium. The detonation produced an asymmetric collapse graben bounded by fractures and scarps up to 2,700 $\mathrm{m}(9,000 \mathrm{ft})$ long. The surface expression of the graben is irregular in comparison to the typical, shallow, cone-shaped or semicircular craters generally characteristic of subsurface detonations.

On December 2, 1969, subsequent additional withdrawals were made for emplacement borings UC-3 and UC-4 under Public Land Order \#4748. Other permits and easements were obtained for exploratory borings, weather stations, and miscellaneous support facilities in Hot Creek Valley.

Following the Faultless test, work continued in preparation for Project Adagio (emplacement hole UC-3) and the drilling of hole UC-4 for a future unnamed test. However, in 1970 a decision was made not to conduct additional testing at the CNTA. As a result decommissioning of CNTA started in 1973 and was completed by October 1974. All drilling sites, equipment, support facilities, and materials, including radiologically contaminated materials, were addressed in the site demobilization. In addition, areas disturbed by AEC operations were also delineated. Though DOE retained control of some limited areas, the U.S. Bureau of Land Management and the U.S. Air Force assumed responsibility for most of the CNTA. The DOE either abandoned or turned over to the BLM all of the borings and wells except five wells which were left open for the LongTerm Hydrologic Monitoring Program (AEC, 1973; 1974).

A radiological survey was completed by Reynolds Electrical and Engineering Company, Inc. (REECo) in 1973 prior to demobilization and restoration of the CNTA site. This survey detected only background radioactivity (REECo, 1973), in 1986 a second radiological and hazardous waste survey was completed by REECo at several off-site DOE facilities, including the CNTA. Again, only background radiation was detected at the CNTA, however, chromium and total petroleum hydrocarbons (from a drilling mud additive) were detected in an uncovered drilling mud pit (REECo, 1986). 


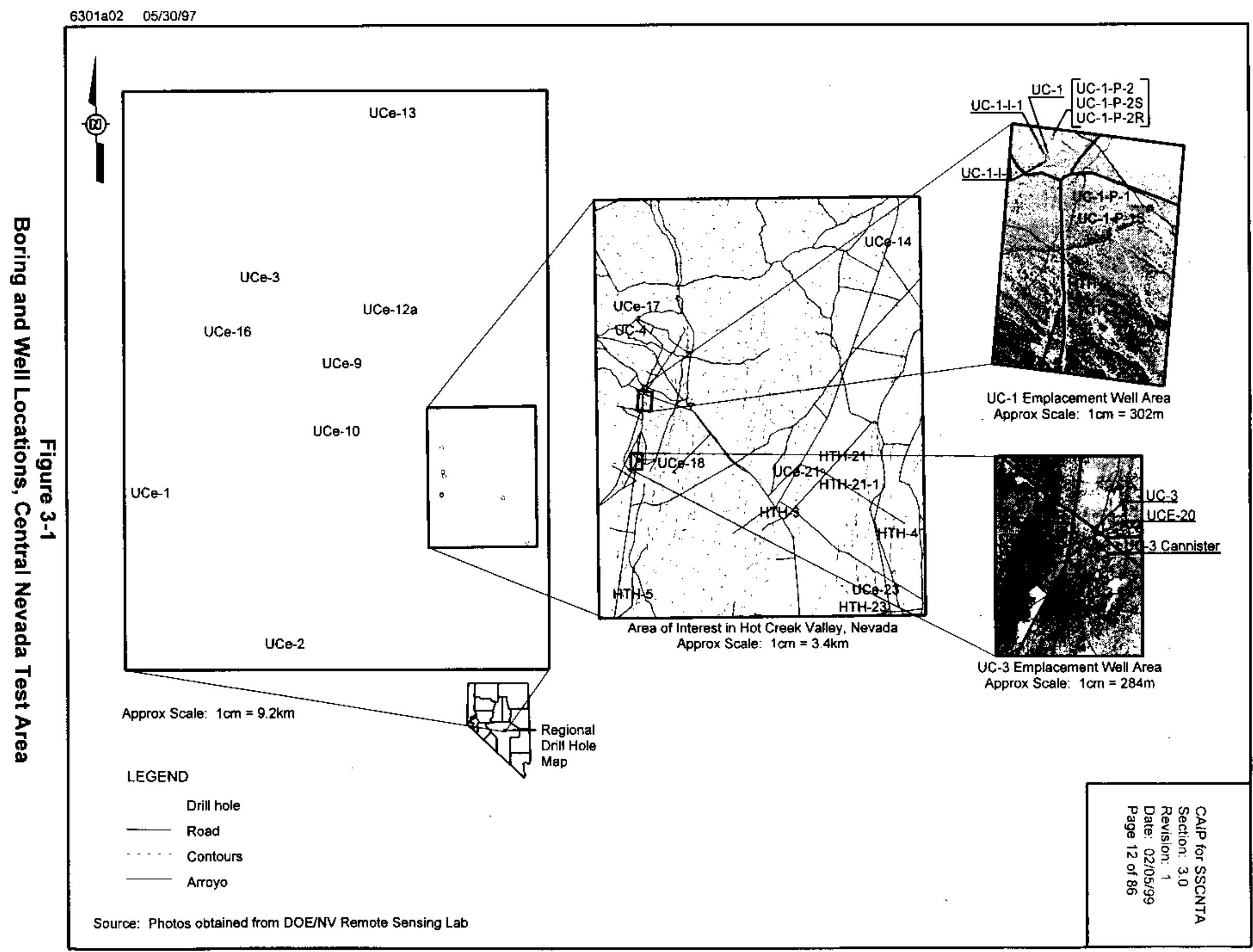


The surface at CNTA was characterized during 1996, 1997, and 1998 and a CADD was prepared. During this evaluation it was determined that chromium concentrations were below the regulatory levels, so the only contaminant of concern identified in the surface material was total petroleum hydrocarbons in the used drilling mud. Bechtel Nevada is currently preparing a Corrective Action Plan for the surface.

\subsection{Corrective Action Sites}

The CNTA subsurface CAU No. 443 consists of three CASs, boreholes UC-1, UC-3, and UC-4, all of which were planned as device emplacement holes. However, only UC-1 was used for the Faultless test, and neither UC-3 nor UC-4 was used as a test site. During the DQO process, it was determined that UC-3 was just an open, cased shaft which should not be evaluated further because there is no evidence of any associated subsurface contamination. Table 3-1 lists the coordinates, depth, and CAS number for each CAS. In accordance with the requirements in the FFACO, DOE will propose to the State of Nevada that CAS 58-30-01 (UC-3) be transferred to the Federal Facility Agreement and Consent Order Appendix IV, "Closed Corrective Action Units."

\subsection{Physical Setting}

\subsubsection{Regional Setting}

Regional groundwater conditions at the CNTA have been generally outlined in several previous studies of the Hot Creek Range and Hot Creek Valley vicinity by DOE, the Desert Research Institute, and the U.S. Geological Survey. The CNTA is located near the eastern flank of the Hot Creek Range on the western slope of the Hot Creek Valley coalesced alluvial fan system. The Hot Creek Valley and Range are a graben and horst pair typical of the Great Basin province in Nevada and the Basin and Range province in Nevada and California. The thick sequence of alluvium in the valley gradually thins to the west to meet the volcanic and carbonate units in the adjacent range. Rush and Everett (1966) mapped a groundwater flow divide in the range that splits groundwater into westerly and easterly components about $8 \mathrm{~km}(5 \mathrm{mi})$ west of the Faultless surface ground zero. 
Table 3-1

Central Nevada Test Area Subsurface Corrective Action Sites

\begin{tabular}{||c|c|c|c||}
\hline CAS Name & $\begin{array}{c}\text { Nevada State } \\
\text { Coordinates }^{\mathrm{a}}\end{array}$ & $\begin{array}{c}\text { Total Depth } \\
\mathrm{m}(\mathrm{ft})^{\mathrm{b}}\end{array}$ & CAS No. \\
\hline \hline UC-1 & $\begin{array}{c}\mathrm{N} 1,414,339.91 \\
\mathrm{E} 628,920.87\end{array}$ & $\begin{array}{c}998 \\
(3,275)\end{array}$ & $58-57-001$ \\
\hline UC-3 & $\begin{array}{c}\mathrm{N} 1,399,948.43 \\
\mathrm{E} 628,092.24\end{array}$ & $\begin{array}{c}1,482 \\
(4,862)\end{array}$ & $58-30-01$ \\
\hline UC-4 & $\begin{array}{c}\mathrm{N} 1,430,564.49 \\
\mathrm{E} 628,253.4\end{array}$ & $\begin{array}{c}1,676 \\
(5,500)\end{array}$ & $58-03-02$ \\
\hline
\end{tabular}

${ }^{a}$ Nevada Central coordinates, NAD27, in feet

${ }^{\mathrm{b}} \mathrm{m}=$ meters; $\mathrm{ft}=$ feet

The hydrogeology of Hot Creek Valley is controlled, in part, by the Basin-and-Range topography. Figure 3-2 is a cross-sectional view across Hot Creek Valley, crossing near the UC-3 withdrawal area, showing geologic contacts and water levels. The valley is a long graben containing a

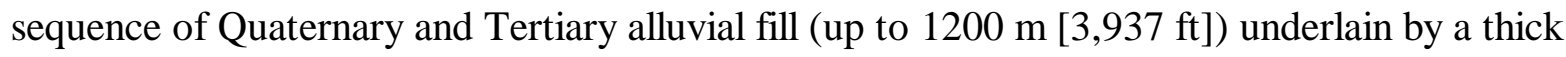
section of Tertiary volcanic rocks. The bounding ranges on either side of the valley contain Paleozoic carbonates overlain by Tertiary volcanics (Thordarson, 1987). Boreholes close to the site generally penetrate approximately $610 \mathrm{~m}(2,001 \mathrm{ft})$ of alluvium underlain by tuffaceous sediments and volcanic rocks.

Hydraulic head measurements in the regional hydrologic system show that the water table in Hot Creek Valley generally occurs within the alluvium (Dinwiddie and Schroder, 1971; Rush and Everett, 1966; Fiero et al., no date). Figure 3-3 is a water level contour map of the alluvial aquifer using 15 water level measurements collected in 1997 and 3 from earlier work, needed where data were not available in 1997. Groundwater in the alluvium is believed to follow the general direction of surface flow (Figure 3-3) (Rush and Everett, 1966; Fiero and Illian, 1969) with recharge in the mountain range to the west (Hot Creek Range) and discharge by evaporation in low portions of the valley (the area around Twin Springs Ranch), with a minor amount of subsurface flow out of Hot Creek Valley to Railroad Valley (Rush and Everett, 1966). Differences in hydraulic head, water chemistry (48 parameters measured in samples from 38 intervals in 11 wells), and temperature suggest that the alluvium and volcanics are distinct 


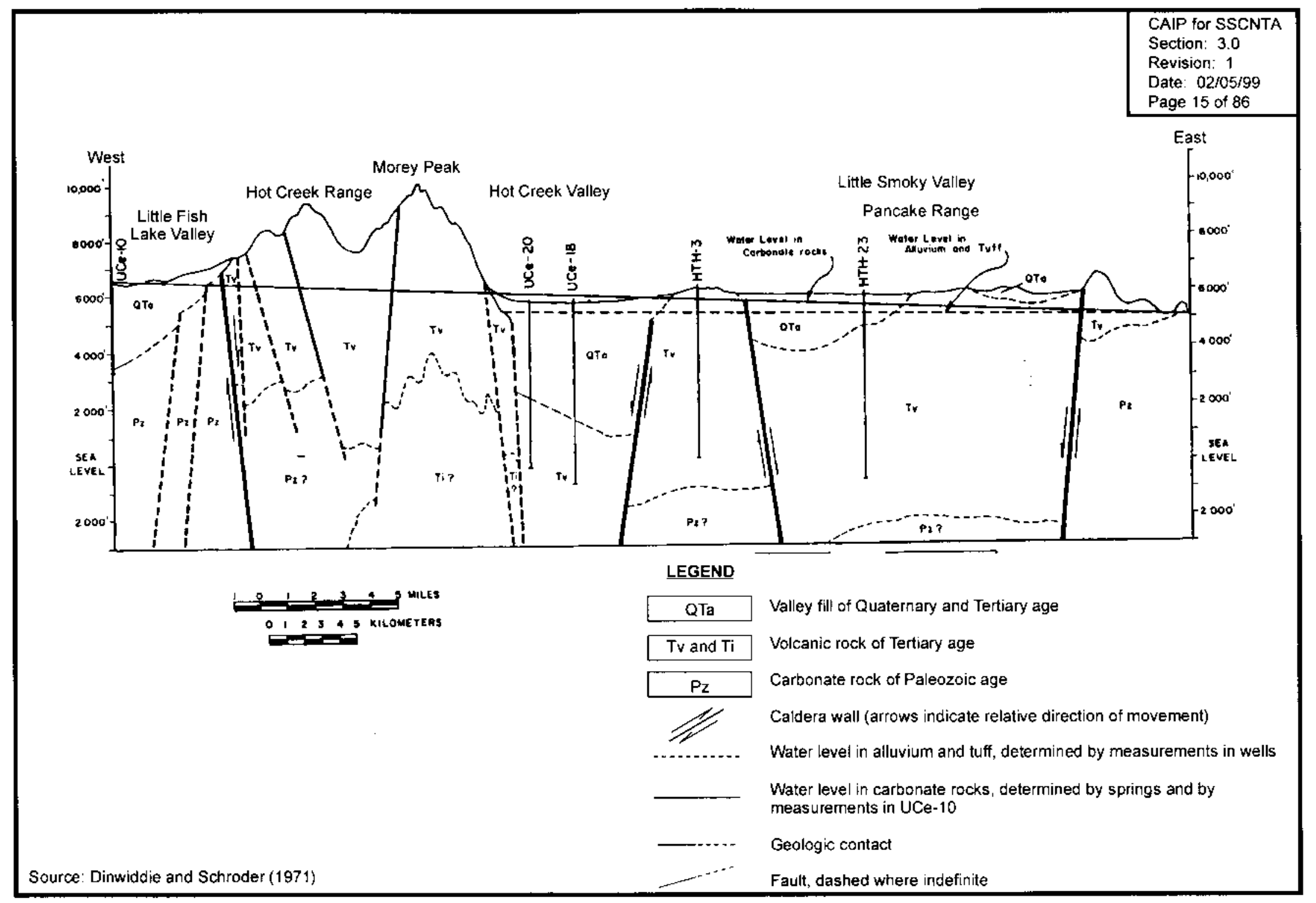

Figure 3-2

Cross Section Across Hot Creek Valley 


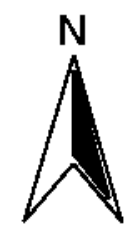

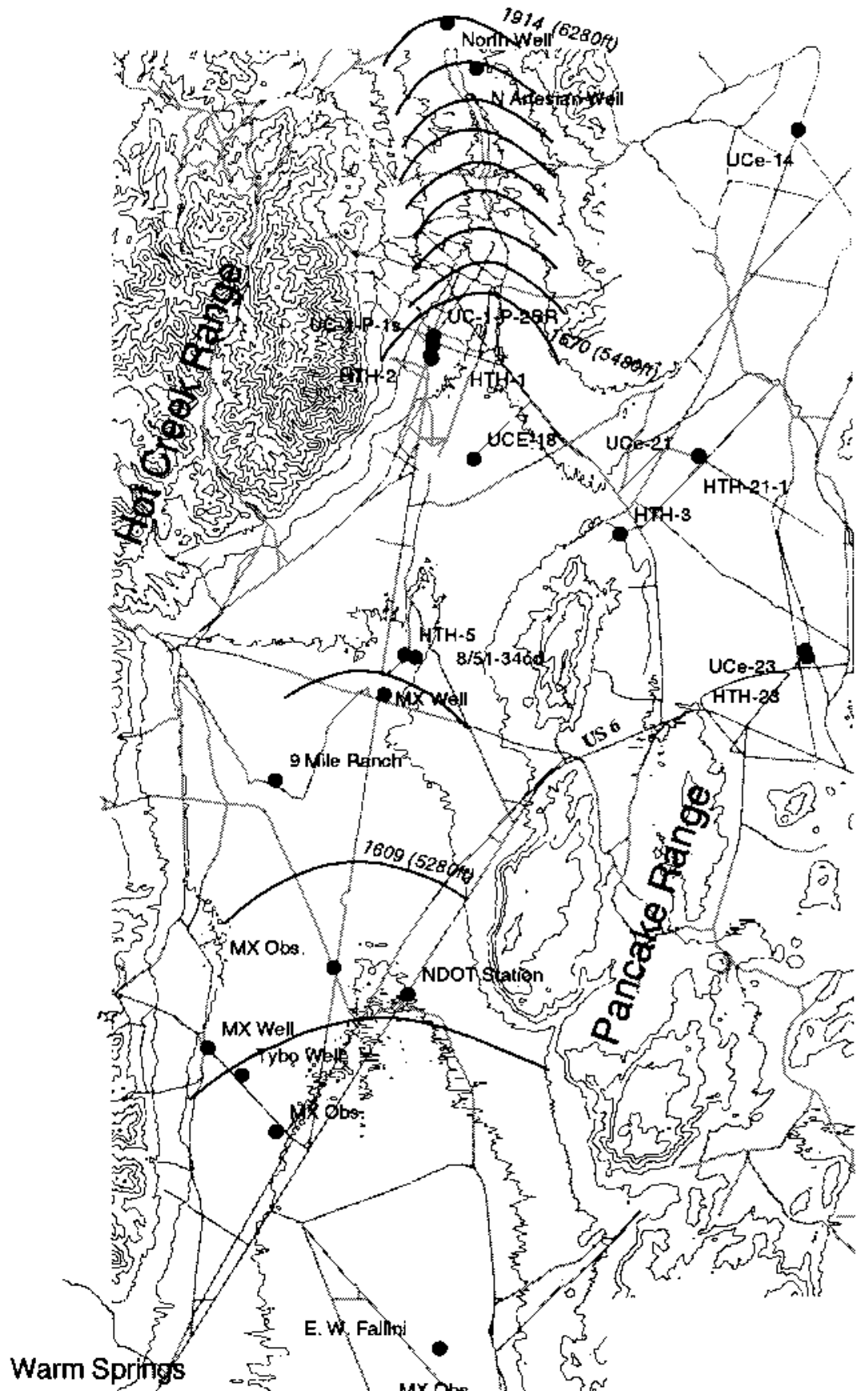

CAIP for SSCNTA

Section: 3.0

Revision: 1

Date: $02 / 05 / 99$

Page 16 of 86 
water-bearing zones (Dinwiddie and Schroder, 1971). Head values in the upper $340 \mathrm{~m}(1,115 \mathrm{ft}$ ) of saturated section indicate that groundwater movement is generally south to southeastward. Head values measured in units 1,500 to $2,100 \mathrm{~m}$ (4,921 to 6,980 ft) below land surface reveal that the deep component of the flow system moves northeastward and eastward to Railroad Valley. Evaluation of vertical head gradients indicates a potential for downward flow in the north end of the valley while an upward potential for flow exists over the southern part of the valley.

\subsubsection{Local Setting}

At the Faultless emplacement hole, UC-1, the valley-fill alluvium is $732 \mathrm{~m}(2,401 \mathrm{ft})$ thick, with tuffaceous sediment and zeolitized tuff below that to the $998 \mathrm{~m}(3,274 \mathrm{ft})$ total depth of the hole (Thordarson, 1987). Other boreholes in the area (HTH-1, UCe-17, UCe-18, UCe-20) also encountered densely welded tuff or rhyolite within the volcanic section.

The alluvium contains pebble- to boulder-size fragments of welded tuff and rare Paleozoic rocks, enclosed in a clay-cemented matrix of sand-sized crystal grains, particles of welded tuff, and some Paleozoic chert, siltstone, and carbonate fragments (Hoover, 1968a). The upper several hundred meters of alluvium are generally unconsolidated, with induration increasing with depth.

The Tertiary tuffaceous sediments include consolidated clastics, which were derived from surrounding volcanic rocks and Paleozoic sediments (Hoover, 1968a). The tuffaceous sediments are similar in texture, fragment sizes (though lacking the larger fragments) and general appearance to the alluvium, but differ in several important ways (Hoover, 1968a). The tuffaceous sediments are more indurated, as a result of zeolitization of volcanic glass and larger amounts of clay matrix materials. The tuffaceous sediments also contain thin intervals of nonwelded zeolitized tuff, densely welded tuff, reworked ash-fall tuff, and tuffaceous sandstones and siltstones. Finally, the tuffaceous sediments display evidence of only minor reworking, very short transportation, and possible active volcanism during deposition.

The Tertiary volcanics consist of tuffs, tuffaceous sediments, sandstones, basalts, and rhyolite lavas ranging in age from Oligocene to Pliocene (Ekren et al., 1973b). The tuffs are generally fine-grained and tightly welded and contain numerous fractures and normal, thrust, and strike-slip faults. 
The immediate test area is in a region of predominantly lateral groundwater flow toward the axis of the valley between the recharge and discharge areas described above. Dinwiddie and Schroder (1971) concluded that vertical movement is slow relative to lateral flow, based on the anisotropy of hydraulic properties.

The Faultless test created a collapse feature much different from the concentric crater usually formed by underground explosions. Instead, a large quasi-sink area formed, bounded by structurally controlled fractures and faults (McKeown et al., 1968). The sink is considered to be a graben, bounded on the northwest, southeast, and south by fractures (Figure 3-4). The northeast margin appears to be a hinge line, with the greatest displacement along the fracture at the south margin. Vertical displacements are as much as $4.5 \mathrm{~m}$, and horizontal displacements are as much as a meter.

Significant hydrologic effects accompanied the geologic impacts of the Faultless test, and these have been monitored through the years (Dinwiddie and West, 1970; Dinwiddie, 1972;

Thordarson, 1985; Thordarson, 1987; Chapman et al., 1994; Mihevc et al., 1996). Water levels in both HTH-1 and HTH-2 responded immediately to the explosion with a short-term pressure increase of $65 \mathrm{~m}$ at HTH-1 and more than $400 \mathrm{~m}$ at HTH-2 (Dinwiddie and West, 1970). The water level measurement was still $39 \mathrm{~m}$ above the pre-test level at HTH-2 one day after the explosion (Figure 3-5), while the maximum head at HTH-1 did not occur until three days after the test. The water levels in HTH-1 and HTH-2 have not returned to pre-event conditions, remaining elevated $6 \mathrm{~m}$ in HTH-1 and $3.7 \mathrm{~m}$ in HTH-2 (Figure 3-5). Two hypotheses have been suggested to account for this long-term change in water levels (Mihevc et al., 1996): the "pre-event" water level reported for HTH-1 may be representative of head in the alluvial aquifer, whereas the current level is representative of natural, higher head, conditions in the volcanic aquifers and has created a mound in the water table that is affecting HTH-2 as well; or a long-term change has occurred in hydraulic conditions (e.g., hydraulic conductivity), caused by the nuclear test.

Two post-shot holes, UC-1-P-1S and UC-1-P-2SR, reflect near-field conditions of the nuclear test. A typical water-level response entails a large, short-lived, hydraulic mound (Figure 3-6), followed by a large depression in the water table centered on the cavity. At this time, 


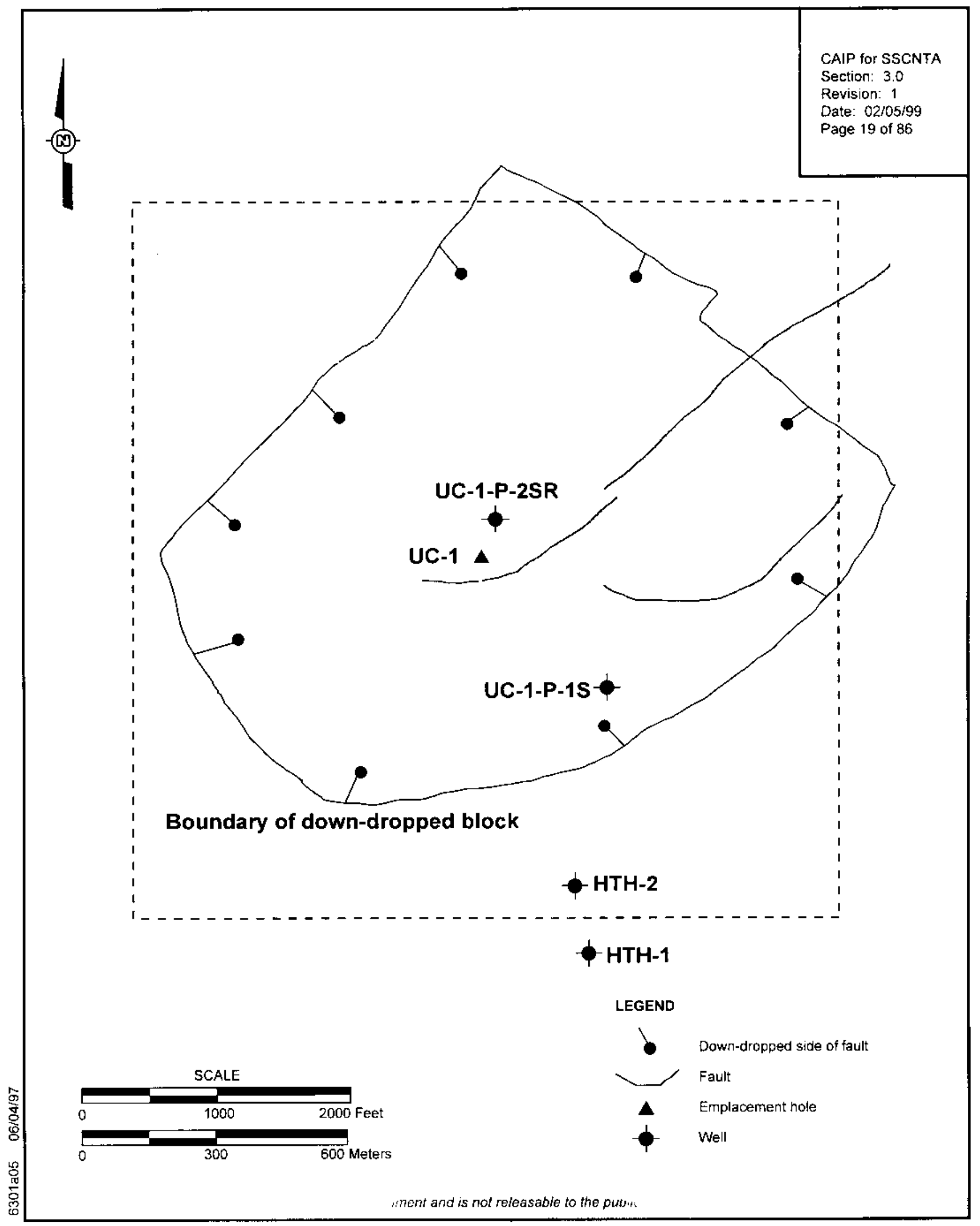

Figure 3-4

Location of Wells Near the Faultless Site 
(a)

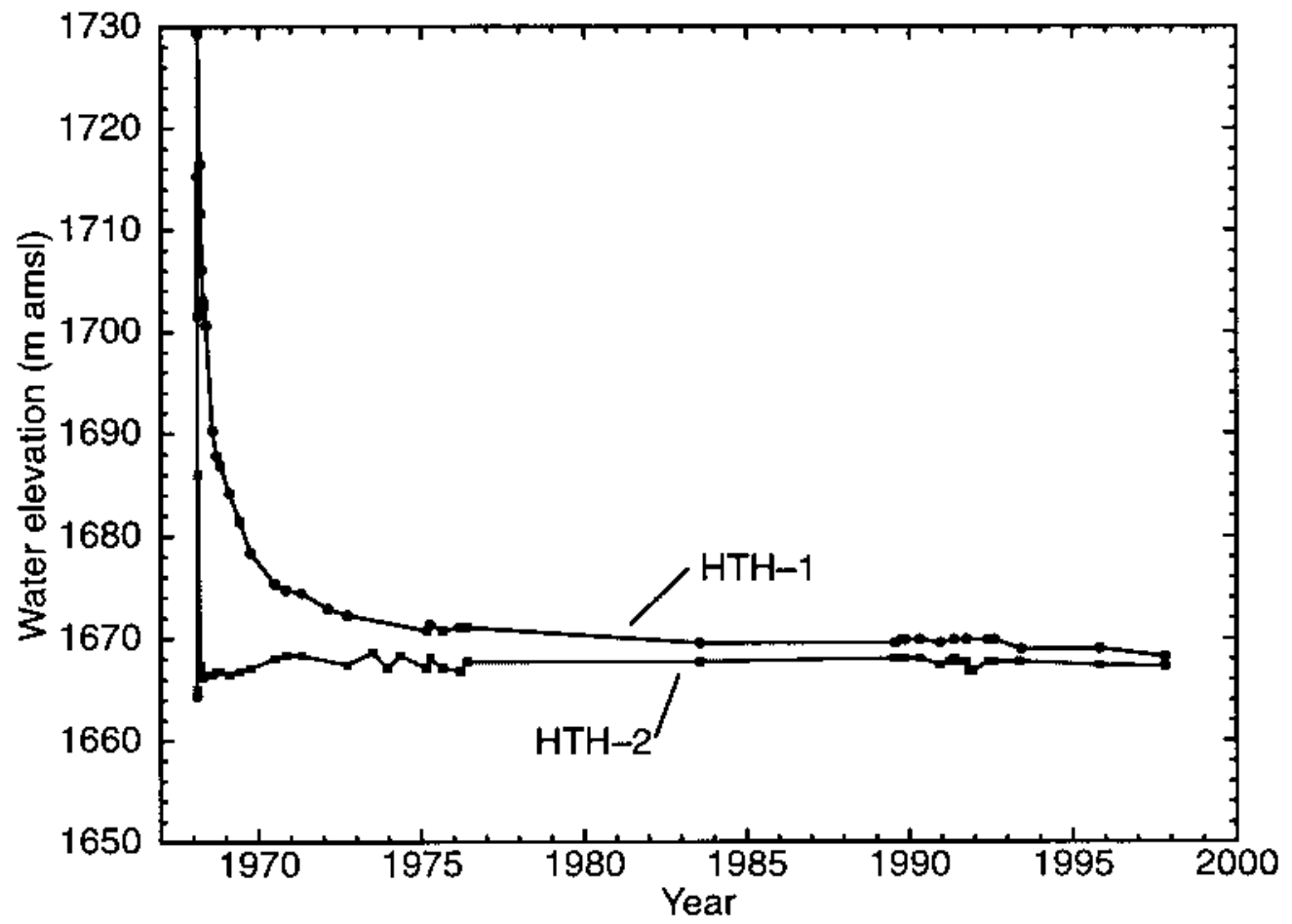

(b)

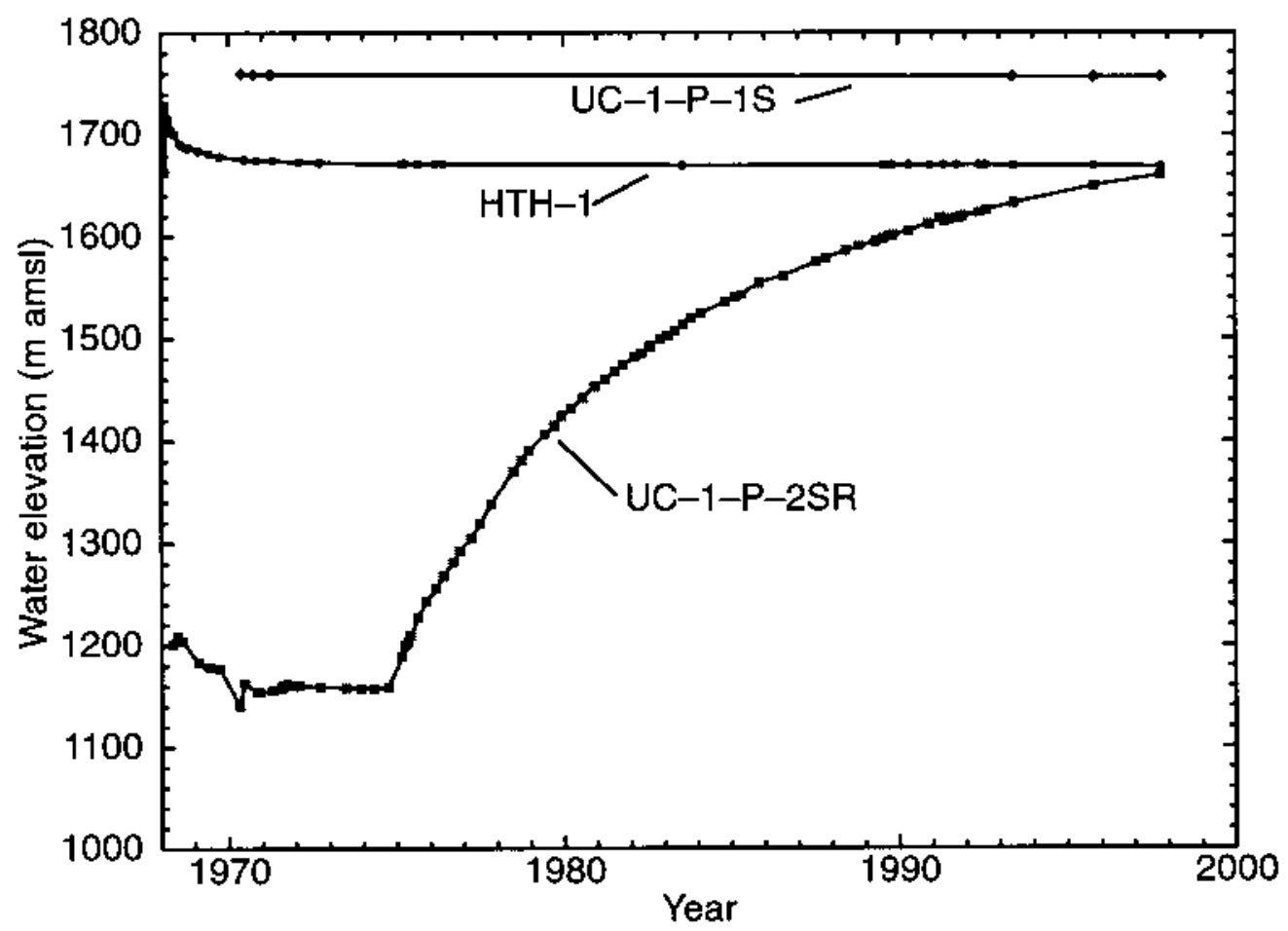

Figure 3-5 


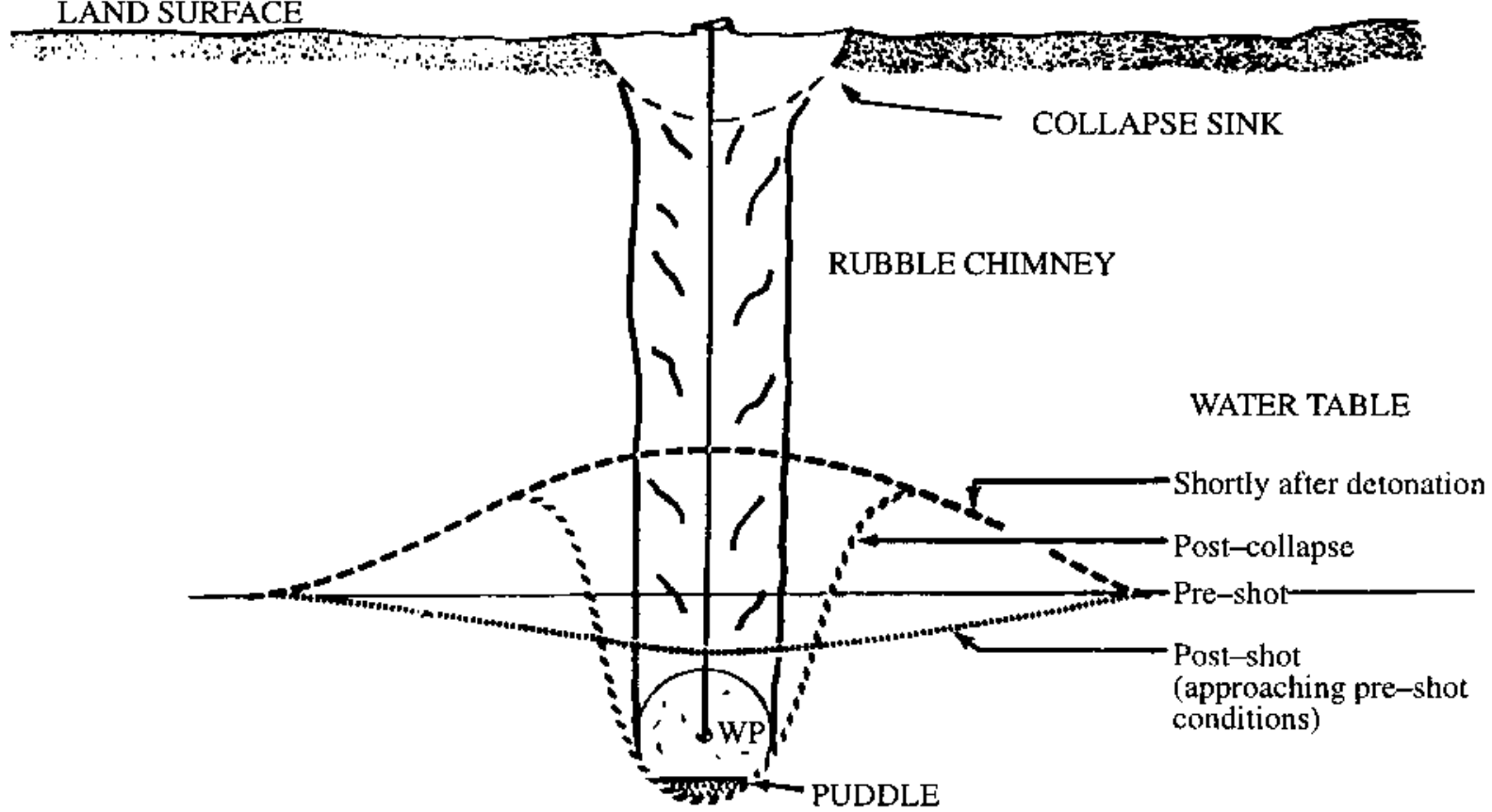

Typical water-table response to a detonation in the saturated zone at Yucca Flat, Nevada Test Site, modified from Gonzalez (1977). These same general features have been recorded by wells near the Faultless test: the elevation of the water table shortly after the detonation can be seen in the hydrographs of wells HTH-1 and HTH-2 (Figure 3-5), and appears to be permanently reflected in the head at UC-1 -P. 1 S presumably due to hydraulic isolation caused by bounding faults created by the test. The post-collapse depression in the water table and subsequent increase approaching pre-shot conditions is recorded by water levels in UC-1-P-2SR (Figure 3-5). 
there is a ring of high heads surrounding the low encompassing the cavity, with this ring also higher than head in the outlying area. The ring eventually subsides, with a general depressed water level around the test, recovering as adjacent groundwater flows toward the low.

Of the two postshot wells, well UC-1-P-1S was drilled first and is strongly deviated from vertical toward the Faultless cavity. Hole conditions caused it to be abandoned, and though there remains access in the well to a measured depth (not corrected for deviation) of approximately $260 \mathrm{~m}$ (853 $\mathrm{ft}$ ), the degree of communication with the underlying hole that originally extended to $833 \mathrm{~m}$ $(2,733 \mathrm{ft})$ is unknown. Artesian conditions were encountered during drilling UC-1-P-1S, soon after the Faultless test, and after a rapid decline from the artesian conditions, the water level has remained reasonably constant, though very elevated, in the well (at a hydraulic head of approximately $1772 \mathrm{~m}$ [5,814 ft]) (Figure 3-5). The sustained, elevated water level may represent the hydraulic mound created by the test that has been preserved between hydraulic barriers created by surrounding faults.

The second post-shot hole, UC-1-P-2SR, was drilled to a depth of $822.9 \mathrm{~m}$, then three sidetrack holes were drilled from that point. The sidetrack that was cased, 2SR, was drilled to a depth of $1097.2 \mathrm{~m}$. The water level in this well is depressed relative to estimated pre-test conditions, but it has been steadily rising (Figure 3-5). Hydraulic head in the well was at $1660.7 \mathrm{~m}$ as of October 1997, as compared to the pre-shot estimate of $1687 \mathrm{~m}$ presented by Thordarson (1987). The depressed water level is the result of thermal and compressional forces generated by the nuclear test and the resultant bulking produced by the collapse of the rubble chimney into the cavity void (Mihevc et al., 1996). The subsequent water-level increase is due to recovery of the cavity and chimney by inflow from surrounding saturated rocks. An analysis of the water level recovery predicts total recovery to the pre-test estimate by the year 2001.

\subsection{Historic Waste Inventory}

The Faultless underground nuclear test produced significant quantities of radionuclides as a result of nuclear reactions and neutron activation. The radionuclides in the post-shot environment are from three primary sources: radioisotopes produced by neutron activation, radionuclides produced by the fission of plutonium-239, and any of the nuclear fuel from the device that was not consumed by the test. The amount (if any) of unburned nuclear fuel (including isotopes of plutonium, uranium, and hydrogen) and the precise types and quantities of radionuclides produced are available in a classified report (Goishi et al., 1995), but unclassified analyses of groundwater from the post-shot well UC-1-P-2SR are publicly available (Thordarson, 1985; Davisson et al., 1994; Chapman et al., 1994). Using the unclassified data and estimates of chimney volume, Pohlmann et al. (1995) calculated a tritium source term for the Faultless test of $4.3 \times 10^{18} \mathrm{pCi}$. 
Davisson et al. (1994) also reported concentrations of up to $27,093 \mathrm{pCi} / \mathrm{L}$ of krypton-85 $\left({ }^{85} \mathrm{Kr}\right)$, $434 \mathrm{pCi} / \mathrm{L}$ of argon-39, and above-background ${ }^{36} \mathrm{Cl} / \mathrm{Cl}$ ratios (the symbol for chlorine is $\mathrm{Cl}$ ) of up to $1 \times 10^{-8}$ in water samples from the post-shot hole, but technetium-99 $\left({ }^{99} \mathrm{Tc}\right)$ was not detected nor was gamma activity above analytical background for ${ }^{60} \mathrm{Co},{ }^{125} \mathrm{Sb}$, and ${ }^{137} \mathrm{Cs}$.

Nonradioactive, but possibly hazardous, materials were also used during emplacement hole drilling, completion, stemming, and testing (Bryant and Fabryka-Martin, 1991). These can include drilling fluids and mud, grout, steel casing, a test rack to support the device and instruments (which can include large quantities of polyethylene and other organic materials, extensive use of lead for shielding, and some other metals), and backfill material (often magnetite powder followed by gravel layers with epoxy plugs).

The contaminants of concern for UC-1 are those radionuclides and hazardous substances created by or remaining after the Faultless test that could be mobile in groundwater. The amount of the radionuclide source term available for transport in groundwater is called the "hydrologic source term" and is smaller than the radiologic source because many of the radionuclides cannot be transported by groundwater due to their incorporation in the relatively insoluble melt glass or rapid decay (Smith et al., 1995). Those radionuclides that do leach slowly from melt debris often have strong sorbing properties that also limit migration. The few radionuclides produced in forms that are mobile in water are of greatest concern for radionuclide transport: tritium, ${ }^{85} \mathrm{Kr},{ }^{36} \mathrm{Cl}$, iodine-125 $\left({ }^{125} \mathrm{I}\right),{ }^{99} \mathrm{Tc}$, and ${ }^{125} \mathrm{Sb}$. Of these, tritium is present in the largest concentration for 100 to 200 years after a test (Smith et al., 1995). Many of the nonradioactive components remaining after the detonation are also expected to be in relatively immobile forms, dependent on mineralogy and geochemical conditions.

The contaminants of concern for UC-4 are the hazardous constituents in the drilling mud that was used during the drilling process. Early REECo analytical data (Table 3-2) indicated the drilling fluids consisted of a bentonite drilling mud with diesel fuel and chrome lignosulfonate additives. The extraction procedure toxicity testing of the samples collected at the mud pit indicated 8 milligrams per liter $(\mathrm{mg} / \mathrm{L})$ of chromium in the leachate. The chromium is likely from chrome lignosulfonate, a drilling mud conditioner used to minimize drilling water loss (DRI, 1988). Additional sampling conducted in 1995 by DOE (Table 3-3) confirmed the 1986 
Table 3-2

Analytical Data from the 1986 REECo Survey

\begin{tabular}{|c|c|c|c|c|c|c|}
\hline \multirow{2}{*}{$\begin{array}{l}\text { Sample } \\
\text { Location }\end{array}$} & \multirow{2}{*}{$\begin{array}{l}\text { Sample } \\
\text { Number }\end{array}$} & \multirow[b]{2}{*}{ Parameter } & \multicolumn{2}{|c|}{ EP ${ }^{\mathrm{a}}$ Toxicity } & \multicolumn{2}{|c|}{ Halocarbon } \\
\hline & & & $\begin{array}{l}\text { Detected } \\
(\mathrm{mg} / \mathrm{L})^{\mathrm{b}}\end{array}$ & $\begin{array}{l}\text { Regulatory Limit } \\
(\mathrm{mg} / \mathrm{L})^{\mathrm{c}}\end{array}$ & $\begin{array}{l}\text { Detected } \\
(\mu \mathrm{g} / \mathrm{kg})^{d}\end{array}$ & $\begin{array}{l}\text { Regulatory Limit } \\
(\mathrm{kg})^{\mathrm{e}}\end{array}$ \\
\hline Runoff Ditch & 1 & Lead & 0.3 & 5.0 & & \\
\hline \multirow{3}{*}{ Central Mud Pit } & 2 (oily crust) & Chromium & 7.9 & 5.0 & & \\
\hline & \multirow{2}{*}{2 (oily dirt) } & 2-Butanone & & & 37 & 1,000 \\
\hline & & Chromium & 8.1 & 5.0 & & \\
\hline
\end{tabular}

${ }_{\text {Extraction Procedure }}^{\mathrm{a}}$

${ }^{\mathrm{b}}$ Milligram(s) per liter

${ }_{d}$ Regulatory limit as listed in Title 40 Code of Federal Regulations (CFR) 261.24 (CFR, 1995)

Microgram(s) per kilogram

Regulatory limit as listed in Title 40 CFR 261.33 (CFR, 1995)

Source: REECo, 1986 
Table 3-3

Central Mud Pit and UC-4 Mud Pit 1995 Analytical Results

\begin{tabular}{|c|c|c|c|}
\hline Sample & $\begin{array}{c}\text { Depth } \\
\text { (in.) }\end{array}$ & $\begin{array}{l}\text { Total Petroleum Hydrocarbons } \\
(\mathrm{mg} / \mathrm{kg})^{b}\end{array}$ & $\begin{array}{c}\text { TCLP }^{\mathrm{a}} \text { Chromium } \\
(\mathrm{mg} / \mathrm{L})^{\mathrm{c}}\end{array}$ \\
\hline \multicolumn{4}{|c|}{ Central Mud Pit } \\
\hline $1 \mathrm{~A}$ & $0-3$ & 680 & 23.0 \\
\hline $2 \mathrm{~A}$ & $3-6$ & 220 & 25.6 \\
\hline $3 \mathrm{~A}$ & $0-3$ & 840 & 15.7 \\
\hline $4 \mathrm{~A}$ & $0-3$ & 190 & 12.3 \\
\hline $5 \mathrm{~A}$ & $0-3$ & 610 & 14.5 \\
\hline $1 \mathrm{~B}$ & $18-21$ & 470 & 0.99 \\
\hline $2 \mathrm{~B}$ & $20-23$ & 150 & 2.20 \\
\hline 3B & $20-23$ & 260 & 1.80 \\
\hline 4B & $20-23$ & 290 & 1.29 \\
\hline $5 \mathrm{~B}$ & $20-23$ & 59 & 1.50 \\
\hline $5 \mathrm{C}$ & $66-72$ & $<25$ & 0.93 \\
\hline $5 \mathrm{D}$ & $72-75$ & $<25$ & 0.65 \\
\hline \multicolumn{4}{|c|}{ UC-4 Mud Pit } \\
\hline $6 \mathrm{~A}$ & $0-3$ & 150 & 6.60 \\
\hline $7 \mathrm{~A}$ & $0-3$ & 96 & 6.80 \\
\hline $8 \mathrm{~A}$ & $0-3$ & 130 & 10.7 \\
\hline $6 \mathrm{~B}$ & $20-23$ & 140 & 0.96 \\
\hline $7 \mathrm{~B}$ & $20-23$ & $<25$ & 0.53 \\
\hline $8 \mathrm{~B}$ & $20-23$ & $<25$ & 10.8 \\
\hline
\end{tabular}

a Toxicity Characteristic Leaching Procedure

The action level (NAC, 1996) for total petroleum hydrocarbons is 100 milligram(s) per kilogram (mg/kg).

C The maximum concentration, as listed in 40 CFR 261.24 (CFR, 1995), for TCLP chromium is $5 \mathrm{mg} / \mathrm{L}$. 
data. More data will be available to confirm or adjust the results once the investigation activities have been completed for the surface CAU No. 417 at CNTA (DOE, 1997).

\subsection{Conceptual Model of the CAU}

The Faultless detonation occurred at a depth of $975 \mathrm{~m}(3,199 \mathrm{ft})$ in Tertiary tuffaceous alluvial fill, a unit which is similar in texture, grain size, and general appearance to the overlying Quaternary alluvium (Hoover, 1968). Groundwater in the test vicinity occurs about $170 \mathrm{~m}$ $(558 \mathrm{ft})$ below ground surface. Thus, the Faultless hydrologic source term is in contact with groundwater. Post-shot drilling data indicate the Faultless shot cavity is about $244 \mathrm{~m}$ (800 ft) in height and is divided almost equally between alluvial and tuffaceous sediments (Thordarson, 1987); thus, contaminant transport could occur through either the alluvium or volcanics or both. Once the rubble chimney is filled with groundwater, migration of contaminants from Faultless will be governed by the transport characteristics of the contaminants and the transport characteristics of the groundwater system.

Nuclear detonations typically cause a temporary unsaturated zone in the immediate vicinity of the blast as a result of high temperatures and pressures and increased porosity in the cavity and chimney. This region of depressed water levels recovers after the test as water from adjacent, saturated sediments infills the cavity and chimney. Significant migration of groundwater, and thus contaminants, away from the test area cannot occur while the hydraulic head in the cavity and chimney is lower than in adjacent aquifers (the force of the nuclear explosion can move some radioactive materials ahead of the cone of depression in a process known as "prompt injection," but the contaminant mass involved is believed to be minor compared to the total mass involved in the test).

\subsection{Corrective Action Levels}

At UC-1, the modeling objective is to predict an acceptable contaminant boundary. This will be achieved through flow and transport modeling of contaminants from the underground test through the affected aquifer systems. The contaminant boundary will be provided as part of the Corrective Action Decision Document.

At UC-4, the modeling objective is to define the release function for total petroleum hydrocarbons from the drilling mud. This will be achieved by evaluating the two components of the release function: the hydrodynamics of groundwater flow through the mud-filled borehole, and the chemical dissolution characteristics for total petroleum hydrocarbons from bentonite mud. If the 
DOE determines that contaminant releases are projected that could potentially be a concern for human health or the environment, flow and transport modeling will be performed.

The UC-4 emplacement hole was left full of drilling mud and is uncased from 415 to 5,500 feet below ground surface. At the time the DQOs were written, there was concern regarding hydrocarbon and chromium contamination of drilling mud. Since then, characterization of the surface mud pits has identified only Total Petroleum Hydrocarbons (TPH) as contaminants of concern (DOE, 1998a). As outlined in the DQOs, the samples collected from the central mud pit and UC-4 mud pit are assumed to have the same chemical composition as the mud in the UC-4 emplacement hole. Given the low levels of contamination suspected and the hydrologic properties of the mud-filled hole, it is considered most likely that a Nevada Administrative Code (NAC) 445A.227 a through k exemption will be filed for the UC-4 emplacement hole. To support the decision for an exemption application, a release function for the TPH from the drilling mud-filled hole will be estimated. This function will represent both the hydrologic and chemical aspects of the release. The hydrologic function will consider hydrologic data from the CNTA in general, and specifically near UC-4 when available, as well as estimates of the hydrologic properties of the drilling mud. These data will be used to estimate groundwater flow through the UC-4 borehole. The chemical release will consider the dissolution constant for TPH from the drilling mud, and will be based on laboratory experiments using materials from the surface mud pits. 


\subsection{Summary of Data Quality Objectives, Processes and Results}

A summary of the DQO process detailed on the DQO work sheets in Appendix A is presented in this section. The summary includes a discussion of the DQO approach and the results.

\subsection{Data Quality Approach}

The DQO process is a systematic planning tool for establishing criteria for data type, quantity, and quality and for developing data collection programs that satisfy the needs of the project. It is an iterative, seven-step process:

- State the problem

- Identify the decision

- Identify the inputs to the decision

- Define the study boundaries

- Develop decision rules

- Specify limits on the decision errors

- Optimize the design for obtaining data

These seven steps have been applied to the CNTA subsurface CASs, and they support a course of action for investigating the CNTA CAUs. The worksheets summarizing this process are presented in Appendix A. There is no worksheet for UC-3 because the work group evaluating the objectives for the CNTA subsurface sites determined that, because there is no evidence of regulated contaminants in $\mathrm{UC}-3$, it should not be examined further.

The DQOs implement the FFACO (1996) strategy for underground test site corrective actions, which is to monitor compliance with the CAU boundary. As of the writing of the FFACO, no specific, cost-effective technologies had been demonstrated to either remove radioactive contaminants from the groundwater, stabilize them, or remove the source of the contaminants at the CASs subject to the agreement.

\subsection{Data Quality Objectives Process Results for UC-1}

The summary will be given as concise statements concerning the UC-1 well for each of the seven steps that were used in the DQO process. 


\section{State the Problem}

Radiological and chemical contaminants were probably released into the groundwater when the Project Faultless test was conducted. Do these contaminants pose a current or future threat to human health and/or the environment.

\section{Identify the Decision}

Can a contaminant boundary be established with sufficient confidence and scientific validity using existing data such that an acceptable boundary can be agreed upon.

\section{Identify the Inputs to the Decision}

The inputs required to reach the decision consist mostly of the parameters that go into completing the groundwater model.

\section{Define the Study Boundaries}

The study boundaries at this time are the limits of the withdrawal area, the depth of the deepest hydrostratigraphic unit that is contaminated, and a time limit of 1,000 years on the groundwater transport model.

\section{Develop Decision Rules}

If the uncertainty in the 4-mrem/yr boundary or the chemical of concern action level is unacceptable, then the problem will be reevaluated and negotiated as needed.

\section{Specify the Limits on the Decision}

The upper bound is the region above the action limit where there is a very high comfort level that sample analysis results would correctly identify the sample as contaminated. The lower bound is the detection limit as specified in the laboratory Statement of Work.

\section{Optimize the Design for Obtaining Data}

Develop the CNTA groundwater flow model using existing data.

\subsection{Data Quality Objectives Process Results for UC-4}

The summary will be given as concise statements concerning the UC-4 well for each of the seven steps that were used in the DQO process. 


\section{State the Problem}

Total petroleum hydrocarbons were left in the drilling mud in the UC-4 borehole when it was capped. The hole is uncased from a depth of $415 \mathrm{ft}$. To a total depth of 5,500 feet so the TPH may be migrating in the groundwater.

\section{Identify the Decision}

Is the TPH leaching from the drilling mud into the groundwater and if so how fast is it leaching and how fast is it migrating away from the borehole?

\section{Identify the Inputs to the Decision}

The primary inputs to the decision are how much TPH is present in the drilling mud, is it leachable, and how fast is groundwater moving near the borehole.

\section{Define the Study Boundaries}

The one and one-half square mile withdrawal area around the UC-4 emplacement hole to a depth of 6,000 feet below ground surface.

\section{Develop Decision Rules}

If the contaminants are migrating from the UC-4 shaft, then the risk to potential receptors will be evaluated.

\section{Specify the Limits on the Decision}

The upper bound is the region above the action limit where there is a very high comfort level that sample analysis results would correctly identify the sample as contaminated. The lower bound is the detection limit as specified in the laboratory Statement of Work.

\section{Optimize the Design for Obtaining Data}

The mud from the uncovered mud pits has been analyzed (DOE/NV, 1998a) and the only contaminant of concern is the TPH. A NAC 445A.227 a through k exemption will be requested. 


\subsection{Corrective Action Investigation}

Appendix VI of the Federal Facility Agreement and Consent Order (1996) details the strategy that the U.S. Department of Energy will use to achieve closure of the underground nuclear test CAUs. The objective of the strategy for underground nuclear test sites is to define boundaries around each CAU that establish areas containing water that may be unsafe for domestic and municipal use. This will be achieved by modeling groundwater flow and transport and by estimating the movement of contaminants using hydrogeologic data specific to the CAU.

As shown in Figure 1-1, the first step in the strategy is to assess existing data related to the CAU. References that have been identified are listed in Section 9.0. Following that assessment, the CAU-specific modeling will be conducted, and the model results will be validated using relevant existing or new data, as available. If the model results are judged to be acceptable, the model will be used to define a contaminant boundary, which will be proposed in the Corrective Action Decision Document.

\subsection{Analytic/Numerical Model(s) Applied to CAU Data}

\subsubsection{Model Selection}

Certain capabilities are required of the groundwater flow and contaminant transport codes to meet the modeling objectives and address the hydrogeological conditions at UC-1. Selection of the final codes follows a process whereby available codes are evaluated based on these capabilities, which include:

- Fully three-dimensional processes

- Heterogeneous and anisotropic properties

- Flexible boundary conditions

- Steady-state or transient conditions

- Hydrologic sources and sinks

- Advection, dispersion, adsorption, matrix diffusion

- Radioactive decay, daughter products

- Minimal numerical dispersion

There are additional considerations that relate to running large three-dimensional models of multiple data sets, including capability for multiple realizations, data formats, efficient data handling, pre- and post-processors, efficient numerical solvers, and compatibility with existing software and hardware. Finally, access to the source code provides the opportunity for 
site-specific modifications, so public-domain codes will be preferred. It is likely that separate codes may be used for the flow and transport steps.

\subsubsection{Model Discussion/Documentation/Data Availability}

\section{Model Discussion}

The land withdrawal area around the UC-1 Faultless cavity is a $2.6 \mathrm{~km}^{2}\left(1-\mathrm{mi}^{2}\right)$ tract, the southeast corner of which is $\mathrm{S} 67^{\circ} 3433^{\prime \prime W}, 3,367,115 \mathrm{~m}(11,046,966 \mathrm{ft})$ from the southeast corner of Township 9 north, Range 51 east, Mt. Diablo Meridian. This is known as the Project Faultless Withdrawal and was acquired on December 6, 1967, under Public Land Order \#4338. Because the impact of the Faultless test on Nevada's resources is of primary concern, the study area will be expanded around this withdrawal. An additional reason for expanding the study area beyond the legal boundary is the need to have groundwater model boundaries at a sufficient distance from the area of concern so that flow and transport calculations are not overly constrained by the boundary conditions.

The initial study area will include that portion of Hot Creek Valley north of Nevada Highway 375 (Figure 3-4) and slightly east to include hydraulic testing data from several wells in Big Sand Spring Valley. This area will allow inclusion of data from 26 wells to define regional flow conditions around and downgradient from the Faultless test. This also includes many of the wells drilled as part of CNTA investigations for which there are geophysical logs and hydraulic test data. These wells will form the basis for simulating heterogeneity in the groundwater flow environment. Though the precise model boundaries should not be specified until preliminary data analysis occurs, they are unlikely to include the large region described above as the study area. Based on scoping-level calculations (Pohlmann et al., 1995), the downgradient model boundary is likely to extend no farther than the UC-3 withdrawn area, approximately six kilometers to the south (Figure 5-1).

When environmental concerns focus on groundwater transport, a careful description of the subsurface, and hydrogeologic heterogeneity in particular, becomes necessary. To develop support for the transport calculations, there must be an adequate understanding of the geologic and hydrologic environment at CNTA. In virtually all regulated settings in the subsurface, the volume of aquifer modeled is many orders of magnitude greater than the volume of geologic material actually observed or sampled (Journel and Alabert, 1989), and this is also true at CNTA. 


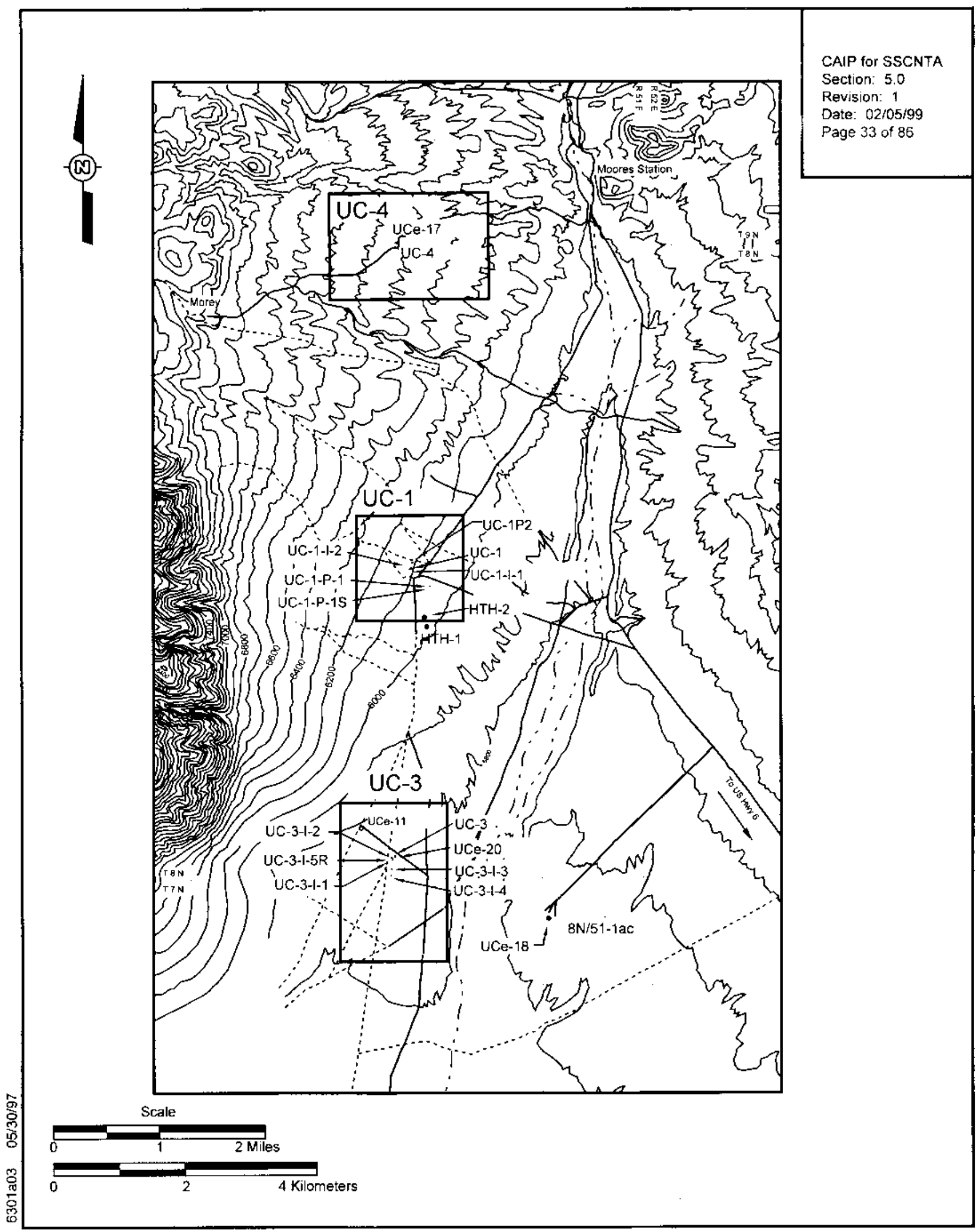

Figure 5-1

Wells Near DOE Land Withdrawals in Northern Hot Creek Valley 
Extrapolation is necessary and introduces significant uncertainty into the geologic understanding. As a result, the modeling effort contains uncertainties that are a direct result of incomplete knowledge.

The approach will be to assemble and synthesize historic well data at CNTA and augment those data with recent measurements of hydraulic and chemical properties. Predictive models will then be created using the observed data, recognizing that the true range in hydrologic parameters may be much greater than observed. Parameter ranges for aquifers in alluvium and volcanic sediments at other sites will be used to help bound the spatial variability possible at CNTA.

The use of all available types of data (geological, geophysical, and hydrological) is needed to describe the geologic heterogeneity at CNTA in three dimensions and to quantify the uncertainty. The first work element will supplement the hydrologic data from former wells, emplacement holes, instrument holes, and existing wells by using geophysical logs. Specifically, resistivity, gamma, and neutron logs will be used to infer permeable zones, and these high-resolution data will be used for stochastic simulations of the three-dimensional subsurface using sequential indicator simulation methods to generate maps of hydrogeologic heterogeneity. This volume-data generation technique has been applied in a variety of environments. For example, sequential indicator simulation methods and geophysical data have been applied to hydrogeologic environments in Central Yucca Flat (Pohlmann and Andrecevic, 1994), at Frenchman Flat (Shirley et al., 1996; Pohlmann et al., 1996), and at the Shoal Site in Churchill County. As described by Alabert (1987), the sequential indicator simulation algorithm estimates a value of the subsurface attribute at an unsampled location such that the new value is consistent with the inferred spatial correlation structure of that variable. The newly simulated value is then added to the existing data set (conditioning data), and the process is repeated. The original conditioning data include only the known data, but as the simulation proceeds, the conditioning data set grows with the addition of each newly simulated data point. Therefore, the final simulated map honors the known data at their locations, as well as the spatial correlation structure inferred from the known data set.

The analysis in Yucca Flat used geophysical log data and sequential indicator simulation methods to infer the three-dimensional distribution of fractured tuffs, while the Shoal application simulates fracture patterns in granite. The sequential indicator simulation method can also include other structural features, such as faults, if needed. Application of the technique to CNTA will involve identifying logs that are likely to distinguish properties important to groundwater flow, correlating between the geophysical logs and available hard data on hydraulic properties (hydraulic 
conductivity), then generating three-dimensional maps of hydraulic conductivity that characterize spatial anisotropy and connectivity patterns to be used as input for a numerical model of groundwater flow. The 58 measurements of hydraulic conductivity from previous CNTA investigations will provide the link between the geophysical data and hydraulic parameters. A large suite of geophysical logs (typically including caliper, gamma, neutron, density, temperature, resistivity, velocity, and three dimensional velocity) is available for over 20 wells, in addition to cores and cuttings.

Difficulties applying the technique to CNTA center on the issue of data density. Though many wells were drilled and tested prior to the Faultless test (Dinwiddie and Schroder, 1971), the purpose of the drilling program was to select a location for CNTA, so the wells are spread out through several valleys (Hot Creek, Little Fish Lake, Monitor, and Little Smoky) with many kilometers between wells. Although several wells are located close to the Faultless test, the nuclear test has altered the natural hydrologic system, and the role the down-dropped block and faults play in flow and transport is not clearly understood. These problems will persist in the flow modeling, although the flow calculations will have the advantage of the three-dimensional permeability structure based on geophysical data.

The groundwater flow model will be based on the three-dimensional maps of hydraulic conductivity and will be used to solve for groundwater flux at all cells of the model domain, given the gradient of hydraulic head. The fluxes are converted to groundwater velocities using the value of effective porosity appropriate for each cell of the model. Three codes that incorporate the capabilities and considerations for modeling groundwater flow at CNTA include MARFLOW (Mose et al., 1994), TOUGH-2 (Preuss, 1991), and FEHMN (Zyvoloski et al., 1995).

Contaminant migration by advection and dispersion will then be simulated using the particletracking random-walk (PTRW) method and the previously simulated velocity fields that include the hydrogeologic heterogeneity. The PTRW method has several important advantages over other numerical methods for solving contaminant migration problems, including ease of implementation, inherent conservation of mass, and lack of numerical errors (Tompson et al., 1987). In the PTRW method, the solute mass is divided evenly into a large number of hypothetical indivisible particles. The movement of the particles in the groundwater flow field is primarily a function of the groundwater velocity, and to a lesser degree, the microscopic dispersivity. By increasing the number of particles used in the simulation, the solution becomes more consistent and reliable, and predictions of solute concentrations at specific locations become more accurate. However, the accuracy of the prediction of overall plume 
behavior does not increase to the same degree. Since average plume behavior is of interest in this type of study, the total contaminant mass is generally divided evenly into 10,000 particles. Selection of the PTRW code to be used for transport modeling at UC-1 from the many available public-domain PTRW codes will be based on the capabilities and considerations described previously.

Contaminant plume migration is described in terms of the contaminant breakthrough curve (contaminant mass plotted against time) crossing a specified plane placed at an appropriate distance downgradient from the source and in terms of the spatial distribution at an appropriate time after the release. The breakthrough curve is statistically evaluated using multiple calculations, known as realizations, by superimposing each realization of the breakthrough curve. The ensemble curve obtained in this way is more likely to be representative of actual measurements in the field, as opposed to a single breakthrough curve resulting from a single aquifer realization. A different method is used to estimate the contaminant boundary maps, which delineate the areas of the modeled domain having concentrations of a certain nuclide above the permissible values for drinking water. The contaminant boundary computations require the actual value (classified or unclassified) of the initial mass and the inclusion of the decay computations in the transport model. The decayed concentration distribution is obtained at every time step and then the domain cells are binary-coded based on the concentration value as compared to the permissible limit (one if concentration exceeds limit and zero otherwise). The extent of the contaminant boundary is presented for the horizontal plane and the vertical projection of the modeled zone for the entire simulation time.

The numerical PTRW analysis of contaminant transport is suitable for simulating the threedimensional patterns of plume migration within several kilometers of the source. However, investigation of the effects of possible future downgradient groundwater pumping scenarios at greater distances would result in unwieldy domain sizes, overly large grid spacing, and ultimately, loss of resolution. Additional analyses that involve areas beyond the geographic extent of the numerical model are better handled using the solute flux method. This analytical method evaluates movement of a solute from the source to a plane perpendicular to the direction of flow and is not limited by distance or discretization issues. 
The contaminant migration process is described in Dagan et al. (1992), Andricevic and Cvetkovic (1996), and Andricevic et al. (1994) through the Lagrangian concept of motion following a particle on the Darcy scale. Aquifer heterogeneity is included and represented by the variance of log-hydraulic conductivity, $\sigma^{2}$, and the hydraulic conductivity correlation length, $i$. The variance represents the variability of $\mathrm{K}$ in space and may range from near zero for homogeneous deposits to three, or higher, for extremely variable porous media (Hoeksema and Kitanidis, 1985). Because it is distributed in space, $\mathrm{K}$ usually has some degree of spatial correlation. The correlation length of $\mathrm{K}, i$, represents the distance beyond which there is no correlation between data points. The higher the value of $i$, the greater the spatial continuity of $K$. When the lognormal distribution and the negative exponential covariance function are assumed, the heterogeneous, isotropic hydraulic conductivity field can be statistically characterized by three parameters: $\mu_{\operatorname{lnK}}, \sigma^{2}{ }_{\text {lnK }}$, and $i$. The combination of the spatial variability of aquifer properties and the uncertainty in the estimates of these properties causes the solute flux to be a random function described by a probability density function. The mean and variance of the solute flux are converted to the flux-averaged concentration by dividing by the groundwater flux, $\mathrm{Q}$. Importantly, the variance of the solute flux allows calculation of the standard deviation so that the transport results can be presented within desired confidence intervals.

As discussed by Smith et al. (1995), there are a number of factors that complicate the release function of various radionuclides from an underground test: heterogeneous spatial and chemical distribution (in melt matrix, on surfaces, etc.), solubility, sorption, and colloid formation. These factors are the focus of an intensive research program at the Nevada Test Site, and the strong analogies between many Nevada Test Site testing areas and the CNTA will allow extrapolating those findings to Faultless. The radionuclides produced by the Faultless test are primarily located within the cavity created by the explosion, though it is possible that a relatively small proportion of the volatile nuclides may have been injected outward by the force of the explosion. Within the cavity, nuclides are distributed according to their volatility among surface deposits and volume deposits in nuclear melt glass. Nuclear melt glass dissolution rates may be calculated using volcanic glass dissolution behavior as an analog. It is assumed that migration of radionuclides will begin once hydraulic head in the cavity recovers to its pre-test condition. Postshot data confirm that the potentiometric level of groundwater in the Faultless cavity has not yet re-equilibrated. Once released, some radionuclides will be subject to retardation reactions. Existing data on sorption properties of CNTA materials (Nork et al., 1971), combined with results from ongoing sorption experiments (see Section 3.1), will be used to describe equilibrium partitioning of radionuclides between the aqueous phase and aquifer material. 


\section{Data Availability}

Historical data sets will be utilized in this modeling effort. These data sets have been generated by numerous individuals over a considerable period of time. Such factors must be kept in mind when questions of confidence arise. Although the data sets will be obtained from sources of known credibility, it will be necessary to ascertain that the quality of the data is appropriate for its intended use.

The reasonableness of the data sets used for CNTA will be determined by reviewing the range and distribution of data points.

The criteria used to select the data sets will be:

- Geographic proximity to the CNTA

- Hydraulic properties pertinent to groundwater flow and transport

- Geologic and geophysical parameters pertinent to hydrogeologic units

- Analogous hydrogeologic environments to CNTA, regardless of geographic proximity.

Regional and local data for hydraulic head and hydrochemical data are described in Section 3.4. Other data to be used in the flow and transport analysis are described below.

Hydraulic conductivity data are available from 58 packer tests and one pumping test. The packer tests were conducted in nine wells with nine measurements in alluvium and 49 measurements in volcanic rock. The aquifer test was conducted in the alluvial section of well HTH-1 with adjacent well HTH-2 used as an observation well (Dinwiddie and Schroder, 1971). The geometric mean of hydraulic conductivity for the nine packer tests in alluvium is 0.02 meters per day $(\mathrm{m} / \mathrm{d})$ with a standard deviation of the natural log of the hydraulic conductivity $(\ln K)$ of 1.35 , where $\mathrm{K}$ is in units of $\mathrm{m} / \mathrm{d}$. The values range from a low of $6.2 \times 10^{-5}$ to a high of $3.6 \times 10^{-1} \mathrm{~m} / \mathrm{d}$. The pumping test at HTH-1 yielded a transmissivity of $102 \mathrm{~m}^{2} / \mathrm{d}$, which results in a range of hydraulic conductivity of between 0.56 and $0.96 \mathrm{~m} / \mathrm{d}$, depending on the assumed thickness of the contributing formation. The range in volcanic rock hydraulic conductivity from the packer tests is from $1.5 \times 10^{-7}$ to $2.1 \mathrm{~m} / \mathrm{d}$ with a geometric mean of $0.072 \mathrm{~m} / \mathrm{d}$ and a standard deviation in $\operatorname{lnK}$ of 1.35. Variogram analysis of the data from volcanic units suggests a vertical correlation scale of about $120 \mathrm{~m}$, according to studies conducted by the Desert Research Institute.

The hydraulic gradient for the water table in the test area was estimated at 0.04 from northwest to southeast by Dinwiddie and Schroder (1971). Further analysis of hydraulic head at CNTA 
suggests that hydraulic gradients are oriented more to the south or southwest. The gradient flattens dramatically downgradient, consistent with surface topography. Considering UCE-17 (near the UC-4 emplacement well to the north of the Faultless test) and UCE-20 and UCE-18 (both south of Faultless), a hydraulic gradient of approximately 0.025 results. When the heads are restricted to the area downgradient from Faultless (HTH-1, UCE-20, and UCE-18), the gradient is 0.004. Using the head at HTH-1 and the one measured at the first supply well downgradient from Faultless, Six-Mile Well, the gradient is 0.002. Dinwiddie and Schroder (1971) report a range of groundwater velocity in the Faultless area of 40 to $70 \mathrm{~m} / \mathrm{yr}$. Pohlmann et al. (1995) used a velocity of $42 \mathrm{~m} / \mathrm{yr}$ for transport calculations in the immediate test area and a velocity of 2.8 $\mathrm{m} / \mathrm{yr}$ for flow to Six Mile Well.

Vertical-hydraulic gradients in Hot Creek Valley are indicated by pre-test head measurements in packer-isolated intervals and tracer tests in individual boreholes (Dinwiddie and Schroder, 1971). To the north of Faultless, heads at UCe-17 produce a gradient of approximately 0.1 with heads declining with increasing depth, suggesting potential for vertically downward flow of groundwater. Conversely, heads at UCe-18 and UCe-20 to the south of Faultless increase with increasing depth at a gradient of approximately 0.02, suggesting potential for vertically upward flow of groundwater. At Faultless, which is located midway between these areas of strong vertical gradients, pre-test heads at HTH-1 indicate very low vertical gradients. The head measured in the densely welded tuffs in the interval of $1,082.2$ to $1,100.6 \mathrm{~m}(3,550$ to $3,611 \mathrm{ft})$ elevation was slightly higher than heads measured above and below, suggesting potential flow from this unit upward and downward into adjacent units. Static tracer tests confirmed the head distribution showing upward flow in the borehole above the welded tuff and downward flow below. More recent thermal flowmeter measurements also found upward flow in HTH-1 (an obstruction prevented measurements in the bottom portion of the borehole), but at much lower rates (Mihevic et al., 1996). The Faultless test was detonated approximately $200 \mathrm{~m}$ (656 ft) below the bottom of the welded tuff interval noted at HTH-1, at an elevation of $885 \mathrm{~m}(2,904 \mathrm{ft})$ above mean sea level. No direct information exists about vertical hydraulic gradients in the Faultless emplacement hole, though pre-test flow conditions are likely to be similar to conditions at HTH-1, which is located approximately $900 \mathrm{~m}(2,953 \mathrm{ft})$ to the southeast.

Effective porosity has not been measured directly on the alluvium or tuffaceous sediments of Hot Creek Valley. Values of effective porosity are needed to calculate groundwater velocities for transport calculations. In the absence of site-specific data on effective porosity, it is accepted modeling practice to base estimates of this parameter on published values for similar materials. 
This approach is generally appropriate because the range in values of effective porosity is usually small (one to two orders of magnitude) when compared to the range of hydraulic conductivity, which ranges over 12 orders of magnitude. Thus, there is considerably less uncertainty associated with estimates of effective porosity than hydraulic conductivity. Examination of cores, cuttings, and logs from wells drilled at and near Faultless led Hoover (1968) to conclude that the tuffaceous sediments and alluvium are very similar in texture and fragment size, though the tuffaceous sediments are more indurated and contain thin layers of volcanic ash. The alluvium is poorly sorted and contains fragments of volcanic and carbonate rock, similar to the alluvium in basins at the Nevada Test Site. The alluvium comprising the fans in northern Frenchman Flat at the Nevada Test Site has been studied extensively as part of site characterization activities for a radioactive waste management facility, and it provides an analog for alluvium in Hot Creek Valley. Porosities for over 200 core samples collected from wells and boreholes in Frenchman Flat are generally greater than 0.30 (REECo, 1993a; 1993b).

\subsubsection{Model Validation}

The process of model validation involves following a modeling protocol - a series of steps which when followed builds support in demonstrating that a given site-specific model is capable of producing meaningful results. The steps of the modeling protocol are:

1) Establishing the model purpose

2) Developing a conceptual model

3) Selection of a computer code and code verification

4) Model design

5) Model calibration

6) Sensitivity and uncertainty analyses

7) Model verification

8) Predictive simulations

9) Presentation of model results

10) Postaudit

A more detailed discussion of most of these steps can be found in American Society for Testing and Materials (ASTM) (1993), Standard Guide for Application of a Ground Water Flow Model to a Site Specific Problem and in Anderson and Woessner (1992). Each of the steps will be discussed individually in the sub-sections below. 


\subsubsection{Model Purpose and Objectives}

The objectives of the model guide the level of detail and accuracy required of the model. The model objectives can be summarized as follows:

a) Integrate a wide variety of data into a mass conservative description of contaminant migration in groundwater from the CNTA underground nuclear test. To the extent practicable, the model will honor observed data to a specified degree of confidence by following the calibration process described in Section 5.1.3.5. In the terms of ASTM (1995), Standard Guide for Subsurface Flow and Transport Modeling, the CAU model can be termed an aquifer simulator. This means the model will be used to assess the value of unknowns at specific locations and times. It also requires a high degree of correspondence between the simulations and the physical hydrogeologic system.

b) Simulate, as output, the concentration of individual contaminants downgradient of the underground test location over a time period of 1,000 years. All of the simulated contaminant concentrations will be evaluated in terms of significant health risk. A composite simulation will be performed with this subset of contaminants to define a contaminant boundary based on a 4 millirems per year (mrem/yr) composite dose.

c) Serve as a tool to evaluate impacts of future flow system changes on the migration of contaminants in the CAU.

\subsubsection{Conceptual Model}

The conceptual model defines the characteristics and dynamics of the hydrogeologic system. Section 3.6 of this document provides a description of the conceptual model. The elements of a conceptual model are defined in ASTM (1996), Standard Guide of Conceptualization and Characterization of Ground-Water Systems. All available data from CNTA will be used to construct the conceptual model. Other non-site specific data may be included in the development of the conceptual model, particularly to provide additional constraints on parameter uncertainty.

\subsubsection{Selection of a Computer Code and Code Verification}

The computer code selection is the process of selecting the appropriate software that is capable of simulating the characteristics of the physical and chemical hydrogeologic system, as identified in the conceptual model to the degree required to meet the objectives. The code selection process is described in Section 5.1.1 of this document. Verification of the code, defined as the process of ensuring that the code algorithms are operating properly, is an important criterion of the code selection process. Typically, code verification is accomplished by comparing the model output to analytical solutions and in some cases results of other numerical models. To fulfill this 
requirement, only codes that have been thoroughly evaluated through a rigorous quality assurance process will be considered in the code selection process.

\subsubsection{Model Design}

Model design is the process of transforming the conceptual model into a mathematical form as described in Section 5.1.2. The process typically includes the data sets and the computer code. This step includes formulation of the model grid, selecting time steps, setting boundary and initial conditions, and preliminary selection of values for aquifer parameters. The natural heterogeneities at CNTA will be simulated via a statistical representation of the spatial distribution of hydraulic conductivity. This method requires parameterization of the statistical properties of the spatial heterogeneity and will provide numerous equiprobable realizations of spatial variability. Therefore, the model will provide predictions of the mean behavior and the uncertainty in the predictions.

\subsubsection{Model Calibration}

As defined in ASTM (1996), Standard Guide for Calibrating a Ground-Water Flow Model Application, model calibration is the process of refining the model representation of the hydrogeologic framework, hydraulic properties, and boundary conditions to achieve a desired degree of correspondence between the model simulations and observations of the groundwater system. The model calibration process has been defined in Section 5.1.2. For the CNTA flow model, the calibration targets will include hydraulic head targets.

\subsubsection{Sensitivity and Uncertainty Analyses}

The sensitivity and uncertainty analyses are quantitative methods of determining the effect of variations in the parameter and boundary conditions (input parameters) on model predictions (output parameters). These analyses will follow ASTM (1994), Standard Guide for Conducting a Sensitivity Analysis for a Ground Water Flow Model Application. The ASTM standard for sensitivity/uncertainty analysis is primarily intended for deterministic models. Because the CNTA model is constructed in a statistical framework, the sensitivity/uncertainty analysis for CNTA will have to be modified slightly from the general concepts of the ASTM approach. The uncertainty in model predictions may focus on the subset of the test related contaminants that are found to be critical in terms of health and safety (e.g., ${ }^{3} \mathrm{H},{ }^{90} \mathrm{Sr},{ }^{137} \mathrm{Cs}$ ). The uncertainty of the composite (4 mrem/yr) contaminant boundary will also be included in the sensitivity/uncertainty analysis. 
The uncertainty in the model output is due to uncertainty in the mean parameters and the natural heterogeneity of the subsurface. The sensitivity analysis will determine how both of these uncertainties will propagate into model output uncertainty. The uncertainty analyses will include bounding calculations that are intended to capture 90 percent of the output uncertainty by choosing uncertainty ranges for the mean input parameters that extend from the 5 to 95 percent levels with the inclusion of the uncertainty due to the natural heterogeneity. This analysis will follow ASTM (1994), Standard Guide for Conducting a Sensitivity Analysis for a Ground Water Flow Model Application to assess the sensitivity of the mean parameters. A Monte Carlo type approach will be used in conjunction with the sensitivity analysis to assess the uncertainty in the natural heterogeneity. Various combinations of the mean parameters (bounded by the 5 to 95 percent uncertainty) will be used in conjunction with a Monte Carlo analysis to assess the general uncertainty in the model output and to determine worst case scenarios of maximum contaminant boundary extent. The model output uncertainty resulting from model input uncertainty and natural heterogeneity will be summarized in tables and figures.

\subsubsection{Model Review}

A thorough review of the model will be performed to verify the modeling approach process and to determine if the modeling process can move forward to the verification phase. The model will be reviewed by three groups: (1) an internal group made up of the DOE Technical Working Group Modeling Subcommittee, (2) DOE management, and (3) NDEP. These groups will be tasked with assessing model adequacy. The internal peer group will be asked to attempt to identify fatal flaws in the model and to evaluate whether the modeling process has been applied correctly. In addition, the peer reviewers will be asked to assess the ranges of parameter uncertainty incorporated into the model and to verify that the range of parameter uncertainty is inclusive. In conjunction with the results of the peer review, DOE management and NDEP will determine if the modeling process can move into the model verification phase by not rejecting the model as presented. If either DOE or NDEP reject the model, DOE and NDEP will enter into discussions to determine how to proceed. If neither DOE nor NDEP reject the model, the model verification phase will begin.

\subsubsection{Model Verification}

Model verification is defined as the testing of predictions of the calibrated model against available data not used in the model production and calibration. 
It may be necessary for additional data to be collected at CNTA for purposes of model verification. However, until the CAU modeling is complete, it is not possible to state what type of data should be collected and whether new wells will need to be installed. The new data collection types and locations will be determined from the model response to the uncertainty and sensitivity analyses. After completion of the model, a verification plan will be prepared and submitted to the NDEP for approval. This plan will identify what data are to be collected, where it will be collected, and the acceptable range of data uncertainty. Data representing both model inputs and model outputs will be collected. These new data potentially may include water levels, model parameters, geochemistry parameters, and contaminant concentrations. These data will be compared against the results of the model predictions consistent with the time period in which the verification data are collected. The data collected for model verification will be designed to provide positive comparison to model inputs and outputs and will be compared with the range of values corresponding to the 5 and 95 percent bounds of the specific parameter.

One of several approaches may be used to determine if the new data verify the model predictions. In the case of data for which the number of values are sufficient to determine a probability distribution factor (pdf), the new data will be shown to be consistent with the previously defined pdf by comparing mean and standard deviation values before and after inclusion of the new data. If the new data do not significantly change the mean and standard deviation, that parameter will be considered verified. In other cases, for which upper and lower bounds have been defined, the new data will be compared with the bounds. The new data will be considered to be verified if the results fall within the 5 and 95 percent ranges defined for that data.

If the data significantly modifies the pdf, or if it falls outside of the 5 and 95 percent ranges, the model will not have been verified. In this case DOE and NDEP will initiate discussions to identify the appropriate path forward.

\subsubsection{Predictive Simulations}

The stated purpose of the CAU model is to provide predictive simulations of radionuclide migration away from the underground test cavity for a period of 1,000 years. For each contaminant, the model will predict the concentration at each node in the model at each time step from 0 to 1,000 years. These data will be processed to calculate a contaminant boundary location. The contaminant boundary is defined as the maximum extent of the $4 \mathrm{mrem} / \mathrm{yr}$ composite dose which is made up of the sum of the doses from each of the contaminants. 
Various combinations of the mean parameters (bounded by the 5 to 95 percent uncertainty) will be used in conjunction with a Monte Carlo analysis to assess the general uncertainty in the calculated maximum boundary extent. The uncertainty in the contaminant boundary will be presented from the calibrated model and from worst case scenarios as determined from an assessment of various combinations of the mean parameters and a Monte Carlo analysis. The simulated contaminant boundary will be presented in both areal figures and cross-sections within the model domain.

\subsubsection{Presentation of Model Results}

The model and results will be presented in the form of a report. The documentation package will include descriptions of the numerical model, the model grid, boundary conditions, aquifer parameter assignments, model calibration, sensitivity analyses and presentation of results. The presentation of the transport simulation will include transport parameters, source term, the location of the $4 \mathrm{mrem} / \mathrm{yr}$ composite dose contaminant boundary and the uncertainty associated with these results with a 1,000 year time period. Additional results showing contaminant concentrations and the location of the contaminant boundary at selected times will also be presented. These times may include the verification period, the end of the five year proof of concept period, as well as other times that are of specific interest.

\subsubsection{Postaudit}

The final component of the validation process is the design of postaudit data collection to provide longer term verification of the model predictions. The postaudit data collection will be integrated as part of the Corrective Action Plan. The details of the postaudit will not be available until the CAP is written. Nonetheless, the general approach to the postaudit will be aimed at continued verification that the model output uncertainty is inclusive of actual future conditions.

The postaudit is designed to be the final stage of a thorough process of model validation designed to demonstrate that the contaminant boundary location has been bounded with reasonable assurance.

\subsubsection{Define Contaminant Boundaries}

Flow and transport modeling for the UC-1 and UC-4 corrective action investigation will be focused on CAS-specific modeling objectives as determined during the DQO process. 
As indicated in Section 3.7, the UC-1 modeling objective is to predict an acceptable contaminant boundary. This will be achieved through flow and transport modeling of contaminants from the underground test through the affected aquifer systems. The contaminant boundary will be provided as part of the Corrective Action Decision Document.

As also indicated in Section 3.7, the modeling objective for UC-4 is to define a release function for the contaminants of concern. Depending on that projected release function, UC-4 may be subject to an a through $\mathrm{k}$ exemption. In that case, no contaminant boundary will be defined. If an a through $\mathrm{k}$ is not considered appropriate, UC-4 will be subject to flow and transport modeling to produce an acceptable contaminant boundary that will be provided as part of the Corrective Action Decision Document. 


\subsection{Field Investigation/No Field Investigation}

\subsection{Topical Areas of Field Investigation}

Previously conducted field investigations relevant to the CNTA subsurface Corrective Action Investigation are described in Section 3.1.

\subsection{No Field Investigation}

In accordance with Sections 3.0 and 5.0 of Appendix VI, "Corrective Action Strategy," of the FFACO (1996), no field investigation is planned to be conducted in this Corrective Action Investigation. Field work, if conducted, would be subject to the requirements of DOE's Health and Safety Plan (DOE, 1996b). Such work would also require the preparation of a site-specific health and safety plan. 


\subsection{Quality Assurance}

This CAIP for CAU No. 443 is designed and will be implemented in accordance with the FFACO (1996) and the Underground Test Area Quality Assurance Project Plan (DOE, 1998b). 


\subsection{Duration and Records/Data Availability}

\subsection{Duration/Data Availability}

The Corrective Action Investigation will begin within 90 calendar days following notification that the Nevada Division of Environmental Protection has approved the plan. The duration of the work described in this plan up to and including the preparation of the Corrective Action Decision Document is planned to be 18 calendar months. Quality-assured results of sampling will initially be available within 90 calendar days of the date on which they are collected for the purposes of this investigation, or in the case of existing data, identified as appropriate for use in the modeling that will be conducted as part of this investigation.

\subsection{Document/Records Availability}

This Corrective Action Investigation Plan is available in the DOE public reading rooms located in Las Vegas and Carson City, Nevada, and from the DOE Offsites Project Manager. The Nevada Division of Environmental Protection maintains the official Administrative Record for all activities conducted under the auspices of the Federal Facility Agreement and Consent Order (1996). For further information about where to obtain documents and other data relevant to this plan, contact Ms. Monica L. Sanchez, Project Manager, Offsites Subproject, at (702) 295-0160. 


\subsection{References}

AEC, see U.S. Atomic Energy Commission.

Alabert, A. 1987. Stochastic Imaging of Spatial Distributions Using Hard and Soft Information, M.S. Thesis. Palo Alto, CA: Stanford University, Applied Earth Sciences Department.

American Society for Testing and Materials. 1993. The Standard Guide for Application of a Ground-Water-Flow Model to a Site-Specific Problem, ASTM D 5447-93. Philadelphia, PA.

American Society for Testing and Materials. 1994. Standard Guide for Conducting a Sensitivity Analysis for a Ground-Water Flow Model Application, ASTM D 5611-94. Philadelphia, PA.

American Society for Testing and Materials. 1995. Standard Guide for Documenting a Groundwater Flow Model Application, ASTM D 5718-95. Philadelphia, PA.

American Society for Testing and Materials. 1996. Standard Guide for Conceptualization and Characterization of Ground-Water Systems, ASTM D 5979-96. Philadelphia, PA.

Anderson, M.P., and W.W. Woessner. 1992. Applied Groundwater Modeling Simulation of Flow and Advective Transport. San Diego, CA: Academic Press.

Anderson, R.E., F.M. Byers, Jr., G.L. Dixon, E.B. Ekren, D.C. Hedlund, E.N. Hinrichs, D.L. Hoover, F.N. Houser, F.J. Kleinhampl, P.P. Orkild, C.L. Rogers, K.A. Sargent, and R.P. Snyder. 1967. Preliminary Reconnaissance Geologic Map of Central Nevada, Technical Letter: Central Nevada-1. Denver, CO: U.S. Geological Survey.

Andricevic, R., and V. Cvetkovic. 1996. "Evaluation of Risk from Contaminants Migrating by Groundwater." In Water Resources Research, Vol. 32, No. 3:611-621. Washington, DC: Elsevier Publishing Co.

Andricevic, R., J. Daniels, and R. Jacobson. 1994. "Radionuclide Migration using Travel-Time Transport Approach and its Application in Risk Analysis." In Journal of Hydrology, 163:125-145. Amsterdam, The Netherlands: Elsevier Publishing Company.

ASTM, see American Society for Testing and Materials.

Bryant, E.A., and J. Fabryka-Martin. 1991. Survey of Hazardous Materials Used in Nuclear Testing, LA-12014-MS. Los Alamos, NM: Los Alamos National Laboratory.

Buddemeier, R.W., J. Rego, and J. Schweiger. 1985. "Faultless (UC1P2SR)." In Radionuclide Migration Project 1984 Progress Report, UCRL-53628. Edited by R.W. Buddemeier and D. Isherwood. Livermore, CA: Lawrence Livermore National Laboratory. 
CFR, see Code of Federal Regulations.

Chaloud, D.J., D.M. Daigler, M.G. Davis, B.B. Dicey, S.H. Faller, C.A. Fontana, K.R. Giles, P.A. Huff, A.A. Mullen, A.C. Neale, F. Novielli, M. Sells, and the Nuclear Radiation Assessment Division. 1996. Radiation Monitoring Around United States Nuclear Test Areas, Calendar Year 1993, EPA 402/R-96/007. Las Vegas, NV: U.S. Environmental Protection Agency, Environmental Monitoring Systems Laboratory, Nuclear Radiation Assessment Division.

Chapman, J., T.M. Mihevc, and B.F. Lyles. 1994. The Application of Borehole Logging to Characterize the Hydrogeology of the Faultless Site, Central Nevada Test Area, 45119, DOE/NV/10845-35. Las Vegas, NV: Desert Research Institute, Water Resources Center.

Code of Federal Regulations. 1995. Title 40 CFR Part 261. Washington, DC: U.S. Government Printing Office.

Dagan, G., V. Cvetkovic, and A. Shapiro. 1992. "A Solute Flux Approach to Transport in Heterogeneous Formations: the General Approach." In Water Resources Research, Vol. 28, No. 5:1, 369-1, 376. Washington, DC: American Geophysical Union.

Davisson, M.L., G. Nimz, G. Hudson, D. Smith, J. Rego, and J. Kenneally. 1994. FY-92 Report on the Isotope Hydrology Characterization of the Faultless Test Site, Nye County, Nevada, UCRL-ID-116133. Livermore, CA: Lawrence Livermore National Laboratory.

Desert Research Institute. 1988. CERCLA Preliminary Assessment of DOE's Nevada Operations Office Nuclear Weapons Testing Areas, Vols. 1 and 2. Las Vegas, NV.

Dinwiddie, G.A. 1968. Hydraulic Testing of Well HTH-21-1 in Central Nevada, Technical Letter Central Nevada-22. Denver, CO: U.S. Geological Survey.

Dinwiddie, G.A. 1969a. Hydraulic Testing of Well HTH-3 in Central Nevada, Central Nevada-35, USGS-474-34. Denver, CO: U.S. Geological Survey.

Dinwiddie, G.A. 1969b. Hydraulic Testing of Well HTH-23 in Central Nevada, Central Nevada-32, USGS-474-23. Denver, CO: U.S. Geological Survey.

Dinwiddie, G.A. 1970a. Analysis of Hydraulic Tests in Hot Creek Valley, Nevada, USGS 474-82. Denver, CO: U.S. Geological Survey.

Dinwiddie, G.A. 1970b. Hydraulic Testing of Well HTH-4 in Central Nevada, Central Nevada-34, USGS-474-31. Denver, CO: U.S. Geological Survey.

Dinwiddie, G.A. 1970c. Hydraulic Testing of Well HTH-5 in Central Nevada, Central Nevada-37, USGS-474-39. Denver, CO: U.S. Geological Survey. 
Dinwiddie, G.A. 1970d. Hydraulic Testing of Wells in Central Nevada, Central Nevada-20, USGS-474-80. Denver, CO: U.S. Geological Survey.

Dinwiddie, G.A. 1972. Summary of Recent Hydrologic Data, Faultless Site, Hot Creek Valley, Nevada. Denver, CO: U.S. Geological Survey.

Dinwiddie, G.A., and S.W. West. 1970. Hydrologic Phenomena at the Faultless Site, Hot Creek Valley, Nevada. Denver, CO: U.S. Geological Survey.

Dinwiddie, G.A., and J.L. Schroder. 1971. Summary of Hydraulic Testing in and Chemical Analyses of Water Samples from Deep Exploratory Holes in Little Fish Lake, Monitor, Hot Creek, and Little Smoky Valleys, Nevada, USGS-474-90. Denver, CO: U.S. Geological Survey.

DOE, see U.S. Department of Energy.

DOE/NV, see U.S. Department of Energy, Nevada Operations Office.

DRI, see Desert Research Institute.

Eberline Instrument Corporation. 1973. Radiation Contamination Clearance Report for Central Nevada Test Area, Eberline Instrument Corporation Report NVO-294-10. Santa Fe, NM: Eberline Instruments.

Ekren, E.B., F.M. Byers, Jr., W.J. Carr, G.L. Dixon, H.W. Dodge, D.C. Helund, E.N. Hinrichs, D.L. Hoover, W.D. Quinlivan, C.L. Rogers, and R.P. Snyder. 1968. "Preliminary Geologic Map of the Hot Creek Valley Area, Nye County, Nevada," Interagency Report Central Nevada-3. Denver, CO: U.S. Geological Survey.

Ekren, E.B., E.N. Hinrichs, and D.L. Hoover. 1970. Preliminary Geologic Map of the Moores Station Quadrangle, Nevada, Central Nevada-36, USGS-474-45. Denver, CO: U.S. Geological Survey.

Ekren, E.B., E.N. Hinrichs, W.D. Quinlivan, and D.L. Hoover. 1973a. Geologic Map of the Moores Station Quadrangle, Nye County, Nevada, Miscellaneous Geologic Investigations, Map I-756. Denver, CO: U.S. Geological Survey.

Ekren, E.B., C.L. Rogers and G.L. Dixon. 1973b. Geologic and Bouger Gravity Map of the Reveille Quadrangle, Nye County, Nevada, Miscellaneous Geologic Investigations, Map I-806. Denver, CO: U.S. Geological Survey.

FFACO, see Federal Facility Agreement and Consent Order.

Federal Facility Agreement and Consent Order. 1996. Agreed to by the State of Nevada, the U.S. Department of Energy, and the U.S. Department of Defense. 
Fiero, G.W., Jr., and J.R. Illian. 1969. Interim report, Regional Hydrology, Hot Creek Valley Flow System, Nye County, Nevada, 44006. Las Vegas, NV: Desert Research Institute, Water Resources Center.

Fiero, G.W., Jr., J.R. Illian, G.A. Dinwiddie, and L.J. Schroder. 1974. Use of Hydrochemistry for Interpreting Ground-Water Flow Systems in Central Nevada, Central Nevada-44, USGS-474-178. Las Vegas, NV: U.S. Geological Survey and Desert Research Institute, Water Resources Center.

Fiero, G.W., Jr., A.L. Mindling, and J.R. Illian. No date. Section B: Regional Groundwater Flow Systems of Central Nevada, 44005. Probably published in 1968 or 1969.

Las Vegas, NV: Desert Research Institute, Water Resources Center.

Goishi, W., J.W. Meadows, N. Namboodiri, D.K. Smith, and J.F. Wild. 1995. Radionuclide Inventory for U.S. Nuclear Tests Conducted Off the NTS and Hydronuclear and Safety Experiments Conducted on the NTS, UCRL-ID-121901. Secret-Restricted Data.

Gonzalez, D.D. 1977. Hydraulic Effects of Underground Nuclear Explosions, Amchitka Island, Alaska, Ph.D Dissertation. Fort Collins, CO: Colorado State University.

Hoeksema, R.J., and P.K. Kitanidis. 1985. "Analysis of Spatial Structure of Properties of Selected Aquifers." In Water Resources Research, Vol. 21:563-572. Washington, DC: American Geophysical Union.

Hoover, D.L. 1968. Lithologic Logs of Drill Holes in the Faultless Area, Hot Creek Valley, Nevada, Technical Letter: Central Nevada-17. Denver, CO: U.S. Geological Survey.

Johnson, T.E., A.E. Hechanova, and M. Pandian. 1996. Nevada Offsites Integrated Risk Assessment, Central Nevada Test Area, Nye County, Nevada. Las Vegas, NV: Harry Reid Center for Environmental Studies, Nevada Risk Assessment/Management Program.

Journel, A.G., and F. Alabert. 1989. "Non-Gaussian Data Expansion in the Earth Sciences." In Terra Nova, Vol. 1:128-134. Washington, DC: International Freedom Foundation.

Magner, J. U.S. Geological Survey. 1996. Personal communication about CNTA well cores and cuttings in USGS Library. Mercury, NV.

McKeown, F.A., D.D. Dickey, and W.L. Ellis. 1968. Preliminary Report on the Geologic Effects of the Faultless Event, Central Nevada-16, USGS 474-65. Denver, CO: U.S. Geological Survey.

Mihevc, T.M. 1996. Letter report, Summary of October 1995 Field Activities at CNTA-Faultless. Las Vegas, NV: Desert Research Institute, Water Resources Center. 
Mihevc, T.M., J.B. Chapman, and B.F. Lyles. 1996. "The Application of Borehole Logging to Characterize the Hydrogeology of the Faultless Nuclear Test Site, Nevada, USA." In Hydrogeology Journal 4(4):83-97. Hanover, Germany: Zerlag Heinz Heise.

Mose, R., P. Siegel, and P. Ackerer. 1994. "Application of the Mixed Hybrid Finite Element Approximation in a Groundwater Flow Model: Luxury or Necessity?" In Water Resources Research, 30(11): 3,001-3,012. Washington, DC: American Geophysical Union.

NAC, see Nevada Administrative Code.

Nevada, State of. 1988. Hydrographic Basin Statistical Summary - Ground Water Basins 001-232. Carson City, NV: State of Nevada Department of Conservation and Natural Resources, Division of Water Resources and Water Planning.

Nevada Administrative Code. 1996. NAC 445A, "Corrective Action." As adopted by the Nevada Environmental Commission, September. Carson City, NV.

Nork, W.E., E.J. Forslow, and E.H. Essington. 1971. Radioactivity in Water, Central Nevada Test Area, Teledyne Isotopes Report NVO-1229-175. Las Vegas, NV: Teledyne Isotopes, Inc.

Pohlmann, K., and R. Andricevic. 1994. Identification of Potential Groundwater Flowpaths Using Geological and Geophysical Data, 45128. Las Vegas, NV: Desert Research Institute.

Pohlmann, K., J. Chapman, and R. Andricevic. 1995. Exposure Assessment of Groundwater Transport of Tritium from the Central Nevada Test Area, 45133, DOE/NV/1158-02. Las Vegas, NV: Desert Research Institute, Water Resources Center.

Pohlmann, K., C. Shirley, and R. Andricevic. 1996. Near-Field Modeling in Frenchman Flat, Nevada Test Site, 45153. Las Vegas, NV: Desert Research Institute.

Pruess, K. 1991. TOUGH-2 - A General Purpose Numerical Simulator for Multiphase Fluid and Heat Flow, LBL-29400. Berkeley, CA: Lawrence Berkeley Laboratory, Earth Sciences Division, University of California.

Quinlivan, W.D., and C.L. Rogers. 1974. Geologic Map of the Tybo Quadrangle, Nye County, Nevada, Miscellaneous Geologic Investigations, Map I-821. Denver, CO: U.S. Geological Survey.

REECo, see Reynolds Electrical and Engineering Co., Inc.

Reynolds Electrical and Engineering Co., Inc. 1973. Radiation Contamination Clearance Report for Central Nevada Test Area, NVO-294-10. Prepared for U.S. Atomic Energy Commission, Nevada Operations Office. Las Vegas, NV. 
Reynolds Electrical and Engineering Co., Inc. 1986. Hazardous Waste Installation Assessment Report. Prepared for the U.S. Department of Energy by D.N. Fauver. Las Vegas, NV.

Reynolds Electrical and Engineering Co., Inc., Special Projects Section. 1993a. Hydrogeologic Data for Science Trench Boreholes at the Area 5 Radioactive Waste Management Site, Nevada Test Site, Nevada. Prepared for the U.S. Department of Energy, Nevada Operations Office. Las Vegas, NV.

Reynolds Electrical and Engineering Co., Inc., Special Projects Section. 1993b. Site Characterization and Monitoring Data from Area 5 Pilot Wells, Nevada Test Site, Nevada. Prepared for the U.S. Department of Energy, Nevada Operations Office. Las Vegas, NV.

Rush, F.E., and D.E. Everett. 1966. Water Resources Appraisal of Little Fish Lake, Hot Creek and Little Smokey Valleys, Nevada. Ground-Water Resources Reconnaissance Series Report 38. Carson City, NV: State of Nevada Department of Conservation and Natural Resources.

Schroder, L.J., W.A. Beetem, and E. Villasana. 1971. Radiochemical Analyses of Water from Wells, Springs and Streams in Central Nevada, USGS-474-97. Denver, CO: U.S. Geological Survey.

Shirley, C., K. Pohlmann, and R. Andricevic. 1996. Three-Dimensional Mapping of Equiprobable Hydrostratigraphic Units at the Frenchman Flat Corrective Action Unit, Nevada Test Site, 45152. Las Vegas, NV: Desert Research Institute.

Smith, D., B. Esser, and J. Thompson. 1995. Uncertainties Associated with the Definition of a Hydrologic Source Term for the Nevada Test Site, UCRL-ID-120322. Livermore, CA:

Lawrence Livermore National Laboratory.

Thordarson, W. 1985. Hydrogeologic Monitoring of the Faultless Site, Nye County, Nevada, Open File Report 84-580. Lakewood, CO: U.S. Geological Survey.

Thordarson, W. 1987. Hydrogeology of the Faultless Site, Nye County, Nevada, Water Resources Investigations Report 86-4342. Denver, CO: U.S. Geological Survey.

Tompson, A.F.B., E.G. Vomvoris, and L.W. Gelhar. 1987. Numerical Simulation of Solute Transport in Randomly Heterogeneous Porous Media: Motivation, Model Development, and Application, UCID-21281. Livermore, CA: Lawrence Livermore National Laboratory.

U.S. Atomic Energy Commission, Nevada Operations Office. 1973. Planning Directive: Demobilization, Restoration and Monitoring, Central Nevada Test Area, NVO-90. Las Vegas, NV: Fenix \& Scisson.

U.S. Atomic Energy Commission, Nevada Operations Office. 1974. Summary Report: Central Nevada Test Area Demobilization and Restoration Activities, NVO-52. Las Vegas, NV. 
U.S. Department of Energy. 1992a. Environmental Measurements Laboratory Procedures Manual, HASL-300, 27th Edition, Vol. 1. New York, NY.

U.S. Department of Energy, Nevada Operations Office. 1996a. Final Environmental Impact Statement for the Nevada Test Site and Off-Site Locations in the State of Nevada, DOE/EIS0243. Las Vegas, NV.

U.S. Department of Energy, Nevada Operations Office. 1996b. Health and Safety Plan, Rev. 2. Las Vegas, NV.

U.S. Department of Energy, Nevada Operations Office. 1997. Corrective Action Investigation Plan for Central Nevada Test Area, Corrective Action Unit 417, Central Nevada Test Area, DOE/NV-450. Las Vegas, NV: IT Corporation.

U.S. Department of Energy, Nevada Operations Office. 1998a. Corrective Action Decision Document for Corrective Action Unit 417: Central Nevada Test Area Surface, Nevada, Appendix D, Rev. 0, DOE/NV-524. IT Corporation: Las Vegas, NV.

U.S. Department of Energy, Nevada Operations Office. 1998b. Underground Test Area Quality Assurance Project Plan, Nevada Test Site, Nevada, DOE/NV-341, Rev. 2. Las Vegas, NV: IT Corporation.

Zyvoloski, G.A., B.A. Robinson, Z.V. Dash, and L.L. Trease. 1995. Models and Methods Summary for the FEHMN Application, LA-UR-94-3787. Los Alamos, NM: Los Alamos National Laboratory. 
Date: $02 / 05 / 99$

Page 57 of 86

\section{Appendix A \\ Data Quality Objectives Worksheets}




\section{STATE THE PROBLEM}

A. Identify the members of the Scoping Team:

1. Scoping Team

DOE/NV

R. Bangerter

P. Sanders

IT Corporation (IT)

P. Gretsky

R. Deshler
NDEP

C. Goewert

K. Beckley

H. van Drielen

Desert Research Institute (DRI)

J. Chapman

R. Andricevic

K. Pohlmann

B. Lyles

T. Mihevc

2. Core Decision Team

R. Bangerter, C. Goewert

3. Primary Decision Makers

S. Mellington, R. Bangerter

B. Develop/Refine the Conceptual Model:

1. List sources of historic data associated with previous data collection activities. Historical data sources are listed in Section 5.0, the reference list for the Corrective Action Investigation Plan, Subsurface CAU No. 443, Central Nevada Test Area, Nevada.

\section{List ongoing activities.}

Surface CAU corrective action investigation

Subsurface CAU corrective action investigation for Emplacement Well UC-3 CAS

Subsurface CAU corrective action investigation for Emplacement Shaft UC-4 CAS

FY97 CNTA continuing studies

Long-Term Hydrological Monitoring Program

Cattle grazing

3. List known or suspected sources of contamination.

CAS No. 58-57-001 - Faultless test cavity

4. List types of contaminants and affected media.

a. Hydrologic source term: radionuclides such as carbon-14, cesium-137, iodine129 , plutonium 239/240, tritium, uranium-238

b. In situ materials: lead, radiochemical detectors, radioactive tracers (yttrium, zirconium, thulium, and lutetium) 
c. Radionuclides in order of decreasing risk from contaminated drinking water as determined by the Technical Working Group Source Term Committee: ${ }^{241} \mathrm{Am}$; ${ }^{239 / 240} \mathrm{Pu} ;{ }^{244} \mathrm{Cm}>{ }^{129} \mathrm{I} ;{ }^{234,238} \mathrm{U} ;{ }^{146} \mathrm{Sm} ;{ }^{134,137} \mathrm{Cs}>{ }^{22} \mathrm{Na} ;{ }^{152,154} \mathrm{Eu}>{ }^{36} \mathrm{Cl} ;{ }^{125} \mathrm{Sb} ;{ }^{14} \mathrm{C}>$ ${ }^{121} \mathrm{Sn} ;{ }^{155} \mathrm{Eu} ;{ }^{99} \mathrm{Tc} ;{ }^{41} \mathrm{Ca} ;{ }^{147} \mathrm{Pm}>{ }^{63} \mathrm{Ni} ;{ }^{151} \mathrm{Sm}>$ tritium

d. Affected medium: groundwater in the vicinity of the shot cavity.

\section{List known or potential routes of migration.}

Horizontal groundwater flow in alluvium and volcanic bedrock and potential vapor transport of tritium through the unsaturated zone.

\section{List known human and environmental receptors.}

At the current time, there are no known human receptors being affected by existing conditions. The only known environmental receptor is the groundwater in the vicinity of the shot cavity.

C. Define the exposure pathway(s)

For purposes of defining an exposure pathway, a human receptor who installs a drinking water well in the aquifer is postulated.

1. Define the exposure pathway(s).

Migration of contaminated groundwater up a borehole during drilling, development, and use of the groundwater resource.

2. Define the current and future land use.

Current and future - cattle grazing and recreation (hunting, camping)

3. Define applicable or relevant and appropriate requirements or preliminary remediation goals.

There are no applicable or relevant and appropriate requirements other than the FFACO.

The boundary restrictions are a dose rate limit defined as $4 \mathrm{mrem} / \mathrm{yr}$ with a 50 percent confidence level, representing the median value, over a 1,000-year period using appropriate exposure scenarios.

4. Develop the exposure scenario.

The exposure of humans during the drilling, development, and usage of groundwater resources

\section{Specify the available resources}

1. Specify monetary budget for the investigation.

To be determined based on budgetary constraints

2. Define relevant time constraints.

There are no current deadlines for this CAIP. 
E. Description of the problem - combine the relevant background information into a concise description of the problem to be resolved.

Central Nevada Test Area was the site of one underground nuclear test which occurred below the water table. The test is likely to have contaminated the groundwater; however, the impact is unknown. The hydrologic flow model for CNTA is currently under development. Specific, proven, cost-effective technologies that are protective of worker safety and health and that have been demonstrated to either remove radioactive contaminants from the groundwater, stabilize them, or remove the source of the contaminants at the CASs do not currently exist. Such technologies may be perfected in the future, which may alter the choice of corrective action at that time. A contaminant boundary will be developed using a CAU-scale model.

\section{IDENTIFY THE DECISION}

A. Identify the principal study question

Can a contaminant boundary be established with sufficient confidence and scientific validity such that an acceptable regulatory compliance boundary can be agreed upon?

B. Identify alternative action that may be taken based on the findings of the investigation - select the actions that will be taken based on the outcome of the field investigation that corresponds with the selected decision

Additional field investigations may be necessary if the flow model, based on existing data, cannot provide an acceptable boundary location.

C. Identify relationships among decisions

1. Prioritize decisions.

a. Are adequate data available to develop the CNTA groundwater flow model so an acceptable contaminant boundary can be defined?

b. After initial modeling is completed, is there enough confidence and validity in the contaminant boundary to be acceptable to all participants?

c. Will the acquisition of additional data be needed to better constrain the model and the contaminant boundary?

2. Determine the logical sequence of actions.

To follow the flow chart in the FFACO, Figure 3-4.

\section{IDENTIFY THE INPUTS TO THE DECISION}

A. Identify the information inputs needed to resolve the decision

1. Model input needed to resolve the decision includes but is not limited to:

a. Scale adequacy for the modeling nodes

b. Source term

c. Release function

d. Transport processes 
e Geological detail

f. Uncertainties in parametric values

g. Geochemistry

h. Hydraulic properties

B. Indicate how to generate the necessary data

1. Review of existing data

\section{Inclusion of results from ongoing studies}

\section{Radionuclide transport analysis and simulation using computer modeling}

C. Determine the basis for establishing contaminant-specific action level(s) - list the possible basis for establishing the action level (e. g., regulatory threshold, risk or exposure assessment, technological limits, reference based, standards, etc.) Radionuclides: $4 \mathrm{mrem} / \mathrm{yr}$ with a 50 percent confidence over a 1,000 year period Chemical Contaminants: Action levels will be determined in accordance with the NDEP Corrective Action regulation and will use the Integrated Risk Information System, RiskBased Corrective Action, and other risk-based data.

D. Identify potential sampling approaches and appropriate analytical methods CAU modeling will be used to determine the contaminant boundary using existing information. The modeling will consider both radionuclide and chemical contaminants. If additional information is required, the regional and local water levels will be verified, discrete interval packer testing will be conducted in well HTH-1, hydrologic logging and sampling will occur in local wells, and sorption studies will be conducted on archived core samples.

\section{DEFINE THE BOUNDARIES OF THE STUDY}

A. Define the geographic areas of the field investigation

1. Define the domain or geographic area within which all decisions must apply (in some cases this may be defined by the Operable Unit).

At this time, the one-square-mile withdrawal area will be used. However, the area to be considered will be adjusted as determined by this study.

2. Specify the characteristics that define the data population of interest.

Scale adequacy

Source term

Release function

Transport processes

Geological detail

Uncertainties in parametric values 
Geochemistry

Hydraulic properties

3. When appropriate, divide the population into strata that have relatively homogenous characteristics.

Hydrostratigraphic units

Types of sources

4. Define the scale of decision making.

The scale of the decision is dependent on the scale of the model.

B. Define the temporal boundaries of the decision to which the study data apply 1,000 years

C. Identify any practical constraints on data collection Budgetary, classification (security issues), regulatory (permitting, FFACO), and schedule (FFACO deadlines) issues; CAU spending priorities; worker health and safety issues

V. DEVELOP A DECISION RULE - DEFINE A LOGICAL BASIS FOR CHOOSING AMONG ALTERNATIVE ACTIONS

A. Specify the parameters that characterize the data base

Ranges of uncertainty associated with the data

B. Specify the action level or preliminary action level for the decision

Radionuclides: $4 \mathrm{mrem} / \mathrm{yr}$ at the 50 percent confidence level

Chemical Contaminants: As required in Nevada Administrative Code (NAC) 445A.2272, 445A.22735, or 445A.2275 (NAC, 1996)

C. Develop the decision rule - Combine the outputs of the previous DQO steps into "If...then..." decision rules that include the parameters of interest, the action levels, and the alternative actions

If the uncertainty in the 4-mrem/yr boundary or the chemical of concern action level is unacceptable, then the problem will be reevaluated and negotiated as needed.

VI. SPECIFY ACCEPTABLE LIMITS ON DECISION ERRORS - SPECIFY DECISION ERROR LIMITS BASED ON THE CONSIDERATION OF THE CONSEQUENCES OF MAKING AN INCORRECT DECISION

A. Determine the upper and lower bounds for the parameter of interest using relevant historical site data

The parameters of interest are the concentrations of the contaminants of concern. The upper bound is the region above the action limit where there is a very high comfort level that sample analysis results would correctly identify the sample as contaminated. The lower bound is the detection limit as specified in the laboratory Statement of Work. 
B. Define both types of decision errors and identify the potential consequences of each If the contaminated area is defined as being larger than it actually is (false positives), more resources could be committed to the corrective action than are necessary.

If the contaminated area is defined as being smaller than it actually is (false negatives), less corrective action might be undertaken than is needed to ensure protection of human health or the environment.

VII. OPTIMIZE THE DESIGN -identify the most resource-effective design for collecting data to decrease the prediction uncertainty, that is expected to satisfy the DQOs. Develop the CNTA flow model. 
DATA QUALITY OBJECTIVES WORKSHEETS FOR THE SUBSURFACE CORRECTIVE ACTION UNIT EMPLACEMENT SHAFT UC-4 CORRECTIVE ACTION SITE

I. STATE THE PROBLEM

A. Identify the members of the Scoping Team:

1. Scoping Team

DOE/NV

R. Bangerter

P. Sanders

IT Corp

P. Gretsky

R. Deshler
NDEP

C. Goewert

K. Beckley

H. van Drielen

$\underline{\mathrm{DRI}}$

J. Chapman

R. Andricevic

K. Pohlmann

B. Lyles

T. Mihevc

2. Core Decision Team

R. Bangerter, C. Goewert

3. Primary Decision Makers

S. Mellington, R. Bangerter

\section{B. Develop/Refine the Conceptual Model:}

1. List sources of historic data associated with previous data collection activities. Historical data sources are listed in Section 5.0, the reference list for the Corrective Action Investigation Plan, Subsurface CAU No. 443, Central Nevada Test Area, Nevada.

2. List ongoing activities.

Surface CAU corrective action investigation

Subsurface CAU corrective action investigation for Emplacement Well UC-3 CAS

Subsurface CAU corrective action investigation for UC-1 Cavity

FY97 CNTA continuing studies

Long-Term Hydrological Monitoring Program

Cattle grazing

3. List known or suspected sources of contamination.

Drilling mud in CAS No. 58-30-02, Emplacement Shaft UC-4

4. List types of contaminants and affected media.

a. Chromium and total petroleum hydrocarbons

b. Affected media: groundwater and drilling mud 
DATA QUALITY OBJECTIVES WORKSHEETS FOR THE SUBSURFACE CORRECTIVE ACTION UNIT EMPLACEMENT SHAFT UC-4

5. List known or potential routes of migration.

Horizontal flow in the groundwater in the volcanic and alluvial aquifers

6. List known human and environmental receptors.

At the current time there are no known receptors being affected by existing conditions.

C. Define the exposure pathway(s)

For purposes of defining an exposure pathway, a human receptor who installs a drinking water well in the aquifer is postulated.

1. Define the exposure pathway(s). Although there are currently no known receptors, humans are postulated to be exposed to groundwater used as drinking water.

2. Define the current and future land use.

Current and future - cattle grazing and recreation (hunting, camping)

3. Define applicable or relevant and appropriate requirements or preliminary remediation goals.

Resource Conservation and Recovery Act

Safe Drinking Water Act

Nevada Administrative Code 445A.226 to .22755, Action Levels for Contaminated Sites

4. Develop the exposure scenario.

Migration of contaminants into and with the groundwater

D. Specify the available resources

1. Specify monetary budget for the investigation.

To be determined based on budgetary constraints

\section{Define relevant time constraints.}

There are no current deadlines for this CAIP.

E. Description of the contamination problem - combine the relevant background information into a concise description of the problem to be resolved.

Central Nevada Test Area was the site of one underground nuclear test and two planned tests which were never conducted. In preparation for the planned tests, two emplacement holes were drilled, UC-3 and UC-4. At UC-4, a 120-inch diameter hole was drilled to 5,500 feet below the ground surface. The hole was not cased below $415 \mathrm{ft}$. When the tests were canceled, the emplacement hole at UC-4 was left full of drilling mud. To close the hole, a 2-inch metal plate was welded to the 120-inch diameter casing and a 15-inch reinforced concrete slab was poured over the steel plate. As a result of these activities, drilling mud is in an open hole that extends below the water table. 


\section{IDENTIFY THE DECISION}

A. Identify the principal study question

Are there contaminants in the drilling mud which are migrating away from the site? Samples collected from the central mud pit and UC-4 mud pit will be used to characterize the mud in the UC-4 emplacement hole.

B. Identify alternative action that may be taken based on the findings of the investigation - select the actions that will be taken based on the outcome of the field investigation that corresponds with the selected decision

1. If contaminants are migrating, the options are:

a. Leave the mud in place and close the site.

b. Leave the mud in place and monitor the migration.

c. If significant migration is occurring, interim water well regulations will be considered relevant and appropriate, and the well will be plugged in accordance with these regulations.

C. Identify relationships among decisions

1. Prioritize decisions.

a. Determine whether there are contaminants of concern in the drilling mud.

b. If so, determine whether they are migrating away from the shaft at UC- 4 at levels of concern.

2. Determine the logical sequence of actions.

See attached flow chart.

\section{IDENTIFY THE INPUTS TO THE DECISION}

A. Identify the information inputs needed to resolve the decision Input needed to resolve the decision includes but is not limited to:

a. Contents of the drilling mud are the same in the UC-4 mud pit and the UC-4 drill hole

b. Engineering data on the shaft cover

c. Release function

d. Diameter of the shaft

e. Depth of the shaft

f. Condition of the shaft cover 
DATA QUALITY OBJECTIVES WORKSHEETS FOR THE SUBSURFACE CORRECTIVE ACTION UNIT EMPLACEMENT SHAFT UC-4

B. Indicate how to generate the necessary data (e. g., sampling, modeling, etc.)

1. Review of existing data

2. Permeameter and leaching tests on mudpit samples.

3. Modeling of contaminant release and migration from the mud

4. Model groundwater flow in the UC-4 area, if needed, based on contaminant release predictions.

C. Determine the basis for establishing contaminant-specific action level(s) - list the possible basis for establishing the action level (e. g., regulatory threshold, risk or exposure assessment, technological limits, reference based, standards, etc.) Action levels will be determined in accordance with the NDEP Corrective Action regulation and will use the Integrated Risk Information System, Risk Based Corrective Action, and other risk-based data.

D. Identify potential sampling approaches and appropriate analytical methods Samples collected from the central mud pit and UC-4 mud pit are assumed to have the same chemical composition as the mud in the UC-4 emplacement hole.

\section{DEFINE THE BOUNDARIES OF THE STUDY}

A. Define the geographic areas of the field investigation

1. Define the domain or geographic area within which all decisions must apply (in some cases this may be defined by the Operable Unit).

The one-and one-half-square-mile withdrawal area around the UC-4 emplacement hole, to a depth of 6,000 feet below ground surface

2. Specify the characteristics that define the population of interest.

The physical and chemical characteristics of the drilling mud

3. When appropriate, divide the population into strata that have relatively homogenous characteristics.

Physical characteristics

Chemical characteristics

4. Define the scale of decision making.

The scale of the decision is dependent on the action level from the NAC 445A.226 to .22755, Action Levels for Contaminated Sites. 
DATA QUALITY OBJECTIVES WORKSHEETS FOR THE SUBSURFACE CORRECTIVE ACTION UNIT EMPLACEMENT SHAFT UC-4

B. Define the temporal boundaries of the decision to which the study data apply 30 years AIHC Exposure Factors Sourcebook.

C. Identify any practical constraints on data collection Budgetary, classification (security issues), regulatory (permitting, FFACO), and schedule (FFACO deadlines) issues; CAU spending priorities; worker health and safety issues

V. DEVELOP A DECISION RULE - DEFINE A LOGICAL BASIS FOR CHOOSING AMONG ALTERNATIVE ACTIONS

A. Specify the parameters that characterize the population of interest Chemical concentration

B. Specify the action level or preliminary action level for the decision Total Petroleum Hydrocarbons - $100 \mathrm{mg} / \mathrm{kg}$

Resource Conservation and Recovery Act - soil Total Chromium (Cr) Toxicity Characteristic Leaching Procedure (TCLP) $>5 \mathrm{mg} / \mathrm{L}$

Safe Drinking Water Act - Total Cr $100 \mu \mathrm{g} / \mathrm{L}$

Resource Conservation and Recovery Act Subpart S Cr${ }^{+6}$ - soil 400 mg/kg

C. Develop the decision rule - Combine the outputs of the previous DQO steps into "If...then..." decision rules that include the parameters of interest, the action levels, and the alternative actions

If the contaminants are migrating from the UC-4 shaft, then the risk to potential receptors will be evaluated.

VI. SPECIFY ACCEPTABLE LIMITS ON DECISION ERRORS - SPECIFY DECISION ERROR LIMITS BASED ON THE CONSIDERATION OF THE CONSEQUENCES OF MAKING AN INCORRECT DECISION

A. Determine the upper and lower bounds for the parameter of interest using relevant historical site data

The parameters of interest are the concentrations of the contaminants of concern. The upper bound is the region above the action limit where there is a very high comfort level that sample analysis results would correctly identify the sample as contaminated. The lower bound is the detection limit as specified in the laboratory Statement of Work.

B. Define both types of decision errors and identify the potential consequences of each If the contaminated area is defined as being larger than it actually is (false positives), more resources could be committed to the corrective action than are necessary.

If the contaminated area is defined as being smaller than it actually is (false negatives), less corrective action might be undertaken than is needed to ensure protection of human health or the environment. 
DATA QUALITY OBJECTIVES WORKSHEETS FOR THE SUBSURFACE CORRECTIVE ACTION UNIT EMPLACEMENT SHAFT UC-4

VII. OPTIMIZE THE DESIGN - identify the most resource-effective design for collecting data to decrease the prediction uncertainty that is expected to satisfy the DQOs. Determine whether Nevada Administrative Code 445A.227 a through k exemption is feasible. If not, then complete fate and transport modeling. 
Revision: 1

Date: $02 / 05 / 99$

Page 70 of 86

\section{Appendix B}

\section{NDEP Comment Review Sheets}




\section{NEVADA ENVIRONMENTAL RESTORATION PROJECT DOCUMENT REVIEW SHEET}






\title{
NEVADA ENVIRONMENTAL RESTORATION PROJECT DOCUMENT REVIEW SHEET
}

Document Title/Number Corrective Action Investigation Plan for the Central Nevada Test

Revision Number Rev. 0

\begin{abstract}
Area Subsurface Sites [Corrective Action Unit No. 443]
\end{abstract}
Reviewer/Organization Sigurd Jaunarajs/NDEP

\begin{tabular}{|c|c|c|c|c|}
\hline $\begin{array}{c}10 . \\
\text { Comment } \\
\text { Number/ } \\
\text { Location }\end{array}$ & $\begin{array}{l}11 . \\
\text { Type }^{a}\end{array}$ & Comment & Comment Response & $\begin{array}{c}14 . \\
\text { Accept }\end{array}$ \\
\hline General 3. & & $\begin{array}{l}\text { The distinction between model calibration and model validation is clouded in } \\
\text { this document. Calibration is a demonstration that model simulations are } \\
\text { capable of producing heads and fluxes that match those measured in the field, } \\
\text { within an acceptable margin of error. The calibration process is completed } \\
\text { before a model is used for predictive simulations. } \\
\text { Validation falls under the idea of "proof-of-concept" and is a procedure for } \\
\text { assessing the validity of model predictions made for the location and } \\
\text { concentration of contaminants. A validation assessment is a measure of the } \\
\text { robustness of the model when new head, flux, or contaminant distribution data } \\
\text { are considered. Validation has elements of what are described in the } \\
\text { literature as model "verification" and "postaudit". Verification involves testing } \\
\text { model results against a data set that is independent of the calibration data. } \\
\text { This is often accomplished by comparing output heads to a second set of } \\
\text { measured heads (in steady state models) or simulating a historic hydrologic } \\
\text { event (in transient mode) for which data are available. Confidence in the } \\
\text { model can be established through a verification exercise that is undertaken } \\
\text { prior to running actual simulations. } \\
\text { A postaudit is a comparison of model predictions with field data collected after } \\
\text { the model-simulation period of time has passed. An "interim audit" may be } \\
\text { more appropriate in the context of this model. That is, a comparison of } \\
\text { predicted output vs. field measured heads, fluxes or concentrations for a } \\
\text { portion of the model-simulated time period is warranted. A five-year time } \\
\text { frame may be appropriate under the provisions of the FFACO. } \\
\text { Model calibration is a rigorous and quantitative exercise. In contrast, } \\
\text { validation as applied here is less stringent and more qualitative than the } \\
\text { calibration process. It is technically infeasible for a model's predictions to be } \\
\text { perfectly validated by field data. Model validation, however, is expected to } \\
\text { provide compelling evidence that the model is representative of the flow } \\
\text { system and that predicted contaminant transport rate and direction are } \\
\text { scientifically reasonable. }\end{array}$ & $\begin{array}{l}\text { This question was addressed through the response } \\
\text { to specific comment \# } 15 \text {. }\end{array}$ & \\
\hline
\end{tabular}




\section{NEVADA ENVIRONMENTAL RESTORATION PROJECT DOCUMENT REVIEW SHEET}

Document Title/Number Corrective Action Investigation Plan for the Central Nevada Test

Revision Number Rev. 0 Area Subsurface Sites [Corrective Action Unit No. 443]

Reviewer/Organization Sigurd Jaunarajs/NDEP

\begin{tabular}{|c|c|c|c|c|}
\hline $\begin{array}{c}10 . \\
\text { Comment } \\
\text { Number/ } \\
\text { Location }\end{array}$ & $\begin{array}{l}11 . \\
\text { Type }^{a}\end{array}$ & Comment & Comment Response & $\begin{array}{l}14 . \\
\text { Accept }\end{array}$ \\
\hline General 4. & & $\begin{array}{l}\text { The investigative approach put forth in this document for the CNTA is exactly } \\
\text { the same as that developed for the UGTA subproject at the NTS. Using this } \\
\text { approach as a basic framework is certainly acceptable. However, the } \\
\text { investigators should not allow themselves to be constrained by the limitations } \\
\text { of the UGTA approach. The CNTA lends itself to a more directed and } \\
\text { focused investigation. CNTA had only one event, while UGTA investigators } \\
\text { must contend with multiple events that are spread widely apart, which makes } \\
\text { dealing practically with the UGTA difficult. For UC-1 the characterization and } \\
\text { analysis should be more precisely detailed, especially since the site is more } \\
\text { remote than the NTS and not under the day to day control of the DOE. } \\
\text { Additionally, the flow and contaminant transport model being constructed } \\
\text { should not be viewed as solely an instrument utilized for site management and } \\
\text { predictive studies. It is also an interpretive tool which may be instructive in } \\
\text { assessing one's understanding of the flow system. It can be used to organize } \\
\text { and synthesize field data and assist investigators in identifying deficiencies in } \\
\text { those data. The model is simply one element of a characterization of the flow } \\
\text { and contaminant transport system. }\end{array}$ & $\begin{array}{l}\text { These are statements and do not require a direct } \\
\text { response other than that they were noted and will } \\
\text { be taken into account. }\end{array}$ & \\
\hline
\end{tabular}

${ }^{\mathrm{a}}$ Comment Types: $\mathrm{M}=$ Mandatory, $\mathrm{S}=$ Suggested.

Return Document Review Sheets to DOE/NV Environmental Restoration Division, Attn: QAC, M/S 505. 


\section{NEVADA ENVIRONMENTAL RESTORATION PROJECT DOCUMENT REVIEW SHEET}

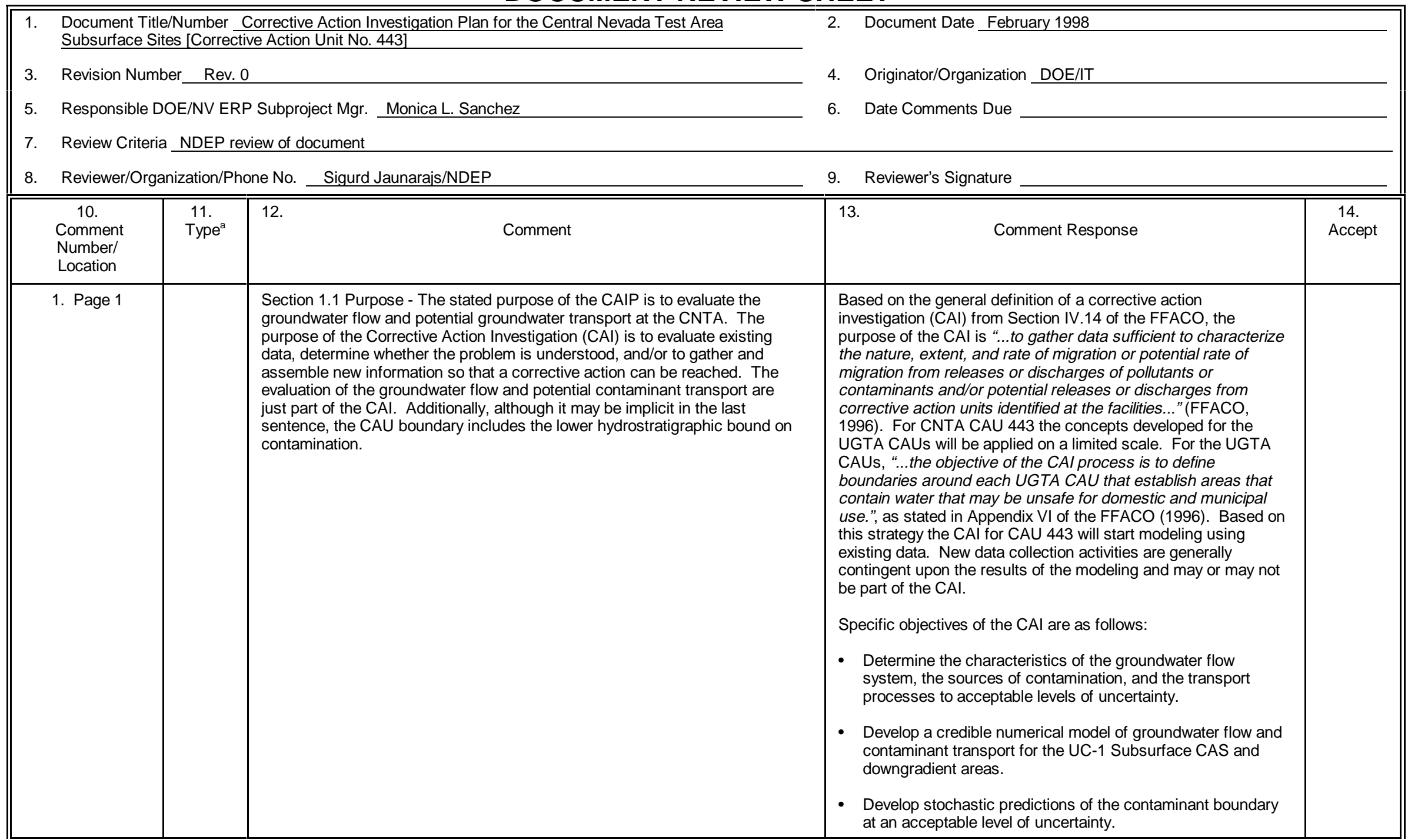




\section{NEVADA ENVIRONMENTAL RESTORATION PROJECT DOCUMENT REVIEW SHEET}

Document Title/Number Corrective Action Investigation Plan for the Central Nevada Test

Revision Number Rev. 0

Area Subsurface Sites [Corrective Action Unit No. 443]

Reviewer/Organization_Sigurd Jaunarajs/NDEP

\begin{tabular}{|c|c|c|c|c|}
\hline $\begin{array}{l}10 . \\
\text { Comment } \\
\text { Number/ } \\
\text { Location }\end{array}$ & $\begin{array}{l}11 . \\
\text { Type }^{\text {a }}\end{array}$ & Comment & Comment Response & $\begin{array}{c}14 . \\
\text { Accept }\end{array}$ \\
\hline 2. Page 1 & & $\begin{array}{l}\text { Section } 1.2 \text { - Scope - This section does not describe the full scope of the } \\
\text { CAl. The section reads as though the scope is only to do modeling using } \\
\text { existing data. This section needs to describe the scope of the plan which will } \\
\text { lead the investigation to the Corrective Action Decision Document. }\end{array}$ & $\begin{array}{l}\text { The second paragraph will be changed as follows, "...(NDEP). } \\
\text { If the modeling results are not accepted the strategy will be } \\
\text { reevaluated to determine if it is achievable. If the strategy is not } \\
\text { achievable a new strategy will be proposed and discussed with } \\
\text { the NDEP. If the strategy is achievable an analysis will be } \\
\text { performed to determine what data are needed to achieve } \\
\text { acceptable modeling results. If, after the acquisition of new } \\
\text { data is complete and the data have been incorporated in the } \\
\text { model, the DOE accepts the modeling results, a boundary will } \\
\text { be established, and the results will be presented to the NDEP. } \\
\text { If the NDEP agrees to the boundary, a Corrective Action } \\
\text { Decision Document (CADD) will be prepared." }\end{array}$ & \\
\hline 3. Page 4 & & $\begin{array}{l}2.0 \text { Overall Legal/Regulatory Requirements - The section has to discuss how } \\
\text { the CAIP will be planned and conducted to be in accordance with the } \\
\text { appropriate investigation purposes of the FFACO. }\end{array}$ & $\begin{array}{l}\text { The entire section was rewritten to discuss how the CAIP will } \\
\text { be in compliance with the FFACO, see new section in the } \\
\text { document. }\end{array}$ & \\
\hline 4. Page 5 & & $\begin{array}{l}\text { In paragraph } 4 \text {, the second sentence states that the flow model of the CNTA } \\
\text { will rely principally on } 91 \text { hydraulic head measurements. Are these at } 91 \\
\text { locations, are they from piezometers, or are they from just a few locations? } \\
\text { The Data Quality Objectives also states on page } 52 \text { that the model will be } \\
\text { restricted to the one square mile of land withdrawal. In order for the model to } \\
\text { rely on these heads, they must be taken within this land withdrawal, or at the } \\
\text { very least near the boundaries. Is this the case? }\end{array}$ & $\begin{array}{l}\text { Replace the second sentence of 4th paragraph with: } \\
\text { "Hydraulic head relationships in the CNTA flow model will be } \\
\text { based on head measurements in exploratory wells constructed } \\
\text { for the CNTA siting investigations and the U.S. Air Force's MX } \\
\text { exploration program, and several water supply wells in Hot } \\
\text { Creek and surrounding valleys. The CNTA data set includes } \\
\text { depth-discrete head measurements made in straddle-packed } \\
\text { intervals in ten of the boreholes (Dinwiddie and Schroder, } \\
\text { 1971). Four of these boreholes are located within or adjacent to } \\
\text { the CNTA UC-1, UC-3 and UC-4 land withdrawals." }\end{array}$ & \\
\hline 5. Page 13 & & $\begin{array}{l}\text { A cursory description of the regional geology is presented in the second } \\
\text { paragraph, however, no geologic characterization of the immediate vicinity of } \\
\text { the UC-1 site is offered. It would be appropriate to include this in section } \\
\text { 3.4.2 Local Setting. }\end{array}$ & $\begin{array}{l}\text { New text describing the local geology was added at the } \\
\text { beginning of Section } 3.4 .2 \text { (given in response to General } \\
\text { Comment 2). }\end{array}$ & \\
\hline
\end{tabular}




\section{NEVADA ENVIRONMENTAL RESTORATION PROJECT DOCUMENT REVIEW SHEET}

Document Title/Number Corrective Action Investigation Plan for the Central Nevada Test

Revision Number Rev. 0

Area Subsurface Sites [Corrective Action Unit No. 443]

Reviewer/Organization_Sigurd Jaunarajs/NDEP

\begin{tabular}{|c|c|c|c|c|}
\hline $\begin{array}{l}10 . \\
\text { Comment } \\
\text { Number/ } \\
\text { Location }\end{array}$ & $\begin{array}{l}11 . \\
\text { Type }^{a}\end{array}$ & Comment & Comment Response & $\begin{array}{c}14 . \\
\text { Accept }\end{array}$ \\
\hline 6. Page 12 & & $\begin{array}{l}\text { Borehole UC-4 is not being investigated for closure. Will it, however, be } \\
\text { plugged in accordance with Nevada Division of Water Resources } \\
\text { Regulations? }\end{array}$ & $\begin{array}{l}\text { The current plan for the UC- } 4 \text { emplacement hole is as follows. } \\
\text { Based on the results of the study of the drilling mud conducted } \\
\text { by DRI, the TPH is not migrating at a significant rate. In } \\
\text { addition the top of the well is sealed with a 2-in thick steel plate } \\
\text { covered by } 2 \text {-ft of reinforced concrete. Since the drilling mud } \\
\text { left in the hole is primarily bentonite and the TPH is not } \\
\text { migrating, nothing would be gained by removing the bentonite } \\
\text { and replacing it with some other backfill material. An a through } \\
k \text { exemption will be prepared. }\end{array}$ & \\
\hline 7. Page 13 & & $\begin{array}{l}\text { The first sentence on the third paragraph states that hydraulic head } \\
\text { measurements are available for } 91 \text { unique positions. It is unclear exactly } \\
\text { what this means - see comment } 4 \text {. }\end{array}$ & $\begin{array}{l}\text { Replace the first two sentences of the third paragraph with: } \\
\text { "Hydraulic head measurements in the regional hydrologic } \\
\text { system show that the water table in Hot Creek Valley generally } \\
\text { occurs within the alluvium (Dinwiddie and Schroder, 1971; Rush } \\
\text { and Everett, 1966; Fiero et al., no date)." }\end{array}$ & \\
\hline 8. Page 23 & & $\begin{array}{l}\text { In the second paragraph it is stated that the geochemical modeling will be for } \\
\text { a } 70 \text { year time frame. Why was } 70 \text { years chosen and what code will be } \\
\text { used? }\end{array}$ & $\begin{array}{l}\text { The timeframe for considering transport from UC- } 4 \text { was decided } \\
\text { to be } 70 \text { years during the DQO process. The last sentence will } \\
\text { be replaced with the following to address the concern regarding } \\
\text { the word "significant": } \\
\text { "If the DOE determines that contaminant releases are projected } \\
\text { that could potentially be a concern for human health or the } \\
\text { environment, flow and transport modeling will be performed." }\end{array}$ & \\
\hline
\end{tabular}




\section{NEVADA ENVIRONMENTAL RESTORATION PROJECT DOCUMENT REVIEW SHEET}

Document Title/Number Corrective Action Investigation Plan for the Central Nevada Test

Revision Number Rev. 0

Area Subsurface Sites [Corrective Action Unit No. 443]

Reviewer/Organization_Sigurd Jaunarajs/NDEP

\begin{tabular}{|c|c|c|c|c|}
\hline $\begin{array}{c}10 . \\
\text { Comment } \\
\text { Number/ } \\
\text { Location }\end{array}$ & $\begin{array}{l}11 . \\
\text { Type }^{\mathrm{a}}\end{array}$ & Comment & Comment Response & $\begin{array}{l}14 . \\
\text { Accept }\end{array}$ \\
\hline $\begin{array}{l}\text { 8. Page } 23 \\
\text { continued }\end{array}$ & & $\begin{array}{l}\text { Though the emphases of the investigation is UC-1, the work being proposed } \\
\text { to investigate UC- } 4 \text { deserves to be expounded upon a little more. }\end{array}$ & $\begin{array}{l}\text { General portion of comment saying to expound on UC-4 } \\
\text { investigation more: The UC-4 emplacement hole was left full of } \\
\text { drilling mud and is uncased from } 415 \text { to } 5,500 \text { feet below } \\
\text { ground surface. At the time the DQOs were written, there was } \\
\text { concern regarding hydrocarbon and chromium contamination of } \\
\text { drilling mud. Since then, characterization of the surface mud } \\
\text { pits has identified Total Petroleum Hydrocarbons (TPH) as the } \\
\text { only contaminants of concern (U.S. DOE, 1997). As outlined in } \\
\text { the DQOs, the samples collected from the Central and UC-4 } \\
\text { mud pits are assumed to have the same chemical composition } \\
\text { as the mud in the UC- } 4 \text { emplacement hole. Given the low levels } \\
\text { of contamination suspected and the hydrologic properties of the } \\
\text { mud-filled hole, it is considered most likely that a Nevada } \\
\text { Administrative Code } 445 A .227 \text { a through k exemption will be } \\
\text { filed for the UC-4 emplacement hole. To support the decision } \\
\text { for an exemption application, a release function for the TPH } \\
\text { from the drilling mud-filled hole will be estimated. This function } \\
\text { will represent both the hydrologic and chemical aspects of the } \\
\text { release. The hydrologic function will consider hydrologic data } \\
\text { from the CNTA in general, and specifically near UC-4 when } \\
\text { available, as well as estimates of the hydrologic properties of } \\
\text { the drilling mud. These data will be used to estimate } \\
\text { groundwater flow through the UC-4 borehole. The chemical } \\
\text { release will consider the dissolution constant for TPH from the } \\
\text { drilling mud, and will be based on laboratory experiments using } \\
\text { materials from the surface mud pits. }\end{array}$ & \\
\hline $\begin{array}{l}\text { 8. Page } 23 \\
\text { continued }\end{array}$ & & $\begin{array}{l}\text { On page } 35 \text { in section } 5.1 .4 \text {, the exact same paragraph on UC- } 4 \text { modeling is } \\
\text { written. Also, the term "significant" as used in the last line of this statement } \\
\text { could be defined. }\end{array}$ & $\begin{array}{l}\text { In order to avoid the repetition noted, the last paragraph of } 5.1 .4 \\
\text { will be replaced by the following: } \\
\text { "As also indicated in Section } 3.7 \text {, the modeling objective for } \\
\text { UC-4 is to define a release function for the contaminants of } \\
\text { concern. Depending on that projected release function, UC-4 } \\
\text { may be subject to an a through k exemption. In that case, no } \\
\text { contaminant boundary will be defined. If an a through k is not } \\
\text { considered appropriate, UC- } 4 \text { will be subject to flow and } \\
\text { transport modeling to produce an acceptable contaminant } \\
\text { boundary that will be provided as part of the Corrective Action } \\
\text { Decision Document." }\end{array}$ & \\
\hline
\end{tabular}




\section{NEVADA ENVIRONMENTAL RESTORATION PROJECT DOCUMENT REVIEW SHEET}

Document Title/Number Corrective Action Investigation Plan for the Central Nevada Test

Revision Number Rev. 0

Area Subsurface Sites [Corrective Action Unit No. 443]

Reviewer/Organization_Sigurd Jaunarajs/NDEP

\begin{tabular}{|c|c|c|c|c|}
\hline $\begin{array}{l}10 . \\
\text { Comment } \\
\text { Number/ } \\
\text { Location }\end{array}$ & $\begin{array}{l}11 . \\
\text { Type }^{a}\end{array}$ & 12. & 13. & $\begin{array}{c}14 . \\
\text { Accept }\end{array}$ \\
\hline 9. Page 24 & & $\begin{array}{l}\text { Section } 4.0 \text { should be a summary of the Data Quality Objectives, and how } \\
\text { they apply to the Corrective Action Investigation. It should be more than } \\
\text { simply a definition of the Data Quality Objectives process. }\end{array}$ & Section 4.0 was rewritten to include a summary of the DQOs. & \\
\hline 10. Page 26 & & $\begin{array}{l}\text { The model study area does not agree with the study area described in the } \\
\text { Data Quality Objectives on page } 52 \text {. The proposed dimensions of the model } \\
\text { should be consistent in various portions of the document, even if the } \\
\text { boundaries cannot be specified at this time. }\end{array}$ & $\begin{array}{l}\text { The one-square mile area given on page } 52 \text { of the DQOs is the } \\
\text { "geographic area within which all decisions must apply", and } \\
\text { coincides with the DOE land withdrawal boundary, not the } \\
\text { model domain. The model study area given on page } 26 \\
\text { identifies a large portion of Hot Creek Valley that will be used as } \\
\text { a source of data for the modeling. As stated in the second } \\
\text { paragraph of } 5.1 .2 \text {, the precise model boundaries will not be } \\
\text { specified until preliminary data analysis occurs, but is unlikely to } \\
\text { encompass the large region used for data. As no actual model } \\
\text { dimensions are proposed at this time, no problem with } \\
\text { consistency in the document can be identified. }\end{array}$ & \\
\hline
\end{tabular}




\section{NEVADA ENVIRONMENTAL RESTORATION PROJECT DOCUMENT REVIEW SHEET}

Document Title/Number Corrective Action Investigation Plan for the Central Nevada Test

Revision Number Rev. 0

Area Subsurface Sites [Corrective Action Unit No. 443]

Reviewer/Organization_Sigurd Jaunarajs/NDEP

\begin{tabular}{|c|c|c|c|c|}
\hline $\begin{array}{l}10 . \\
\text { Comment } \\
\text { Number/ } \\
\text { Location }\end{array}$ & $\begin{array}{l}11 . \\
\text { Type }^{a}\end{array}$ & Comment & Comment Response & $\begin{array}{l}14 . \\
\text { Accept }\end{array}$ \\
\hline $\begin{array}{l}\text { 11. Page } 26 \text { to } \\
31\end{array}$ & & $\begin{array}{l}\text { Section } 5.1 .2 \text { is a discussion of modeling approaches and codes that may be } \\
\text { used, however, the reader is left confused as to what is actually being } \\
\text { planned. The discussion on using a random walk method of particle tracking } \\
\text { combined with a statistical technique to estimate plume breakthrough curves } \\
\text { is then followed by consideration of the solute flux method. It is unclear if } \\
\text { either or both methods are being proposed for plume migration predictions. } \\
\text { This section should relate back to the model selection criteria in section } 5.1 .1 \text {. } \\
\text { A brief discussion of the pros and cons of potential models and approaches } \\
\text { would be instructive. An outline of the methods to be used to evaluate and } \\
\text { decide on codes and approaches is needed. It is not necessary to have } \\
\text { every element of the investigation decided upon in this document, that is if } \\
\text { analysis is required before a decision can be made. The reader should, } \\
\text { however, be left with an understanding of the steps that will be followed } \\
\text { leading to a selection. }\end{array}$ & $\begin{array}{l}\text { Page 30.To clarify the discussion of modeling approaches in } \\
\text { the third paragraph replace the second sentence with: } \\
\text { "However, investigation of the effects of possible future } \\
\text { downgradient groundwater pumping scenarios at greater } \\
\text { distances would result in unwieldy domain sizes, overly large } \\
\text { grid spacing, and ultimately, loss of resolution." } \\
\text { Page 31. First paragraph (this should be a continuation of the } \\
\text { paragraph modified above). At the beginning of the first } \\
\text { sentence, replace "Considering the large distances inherent to } \\
\text { investigations at CNTA, these types of analyses" with the } \\
\text { following: } \\
\text { "Additional analyses that involve areas beyond the geographic } \\
\text { extent of the numerical model" } \\
\text { The following modifications address Comment 11, regarding the } \\
\text { lack of clarity in the discussion of the model selection criteria. } \\
\text { Page 25. In the first sentence of Section 5.1.1, replace the last } \\
\text { words "...for UC-1." with the following: } \\
\text { "and address the hydrogeological conditions at UC-1." } \\
\text { Page 25. Delete the bullet, "Capability for Monte Carlo Runs" } \\
\text { Page 25. Section } 5.1 .1 \text {. Second paragraph, first sentence. Add } \\
\text { the following after the word "including": "capability for multiple } \\
\text { realizations," }\end{array}$ & \\
\hline 12. Page 29 & & $\begin{array}{l}\text { The first sentence of the fourth paragraph states that a particle-tracking } \\
\text { random-walk code will be used to simulate contaminant migration. This is } \\
\text { perhaps misstated. Particle tracking does not simulate contaminant } \\
\text { migration, it only estimates the potential flow paths and travel times for a } \\
\text { group of particles by advection and dispersion, which is different then } \\
\text { simulation of plume migration. }\end{array}$ & $\begin{array}{l}\text { Fourth paragraph, first sentence. To clarify the reference to } \\
\text { particle tracking random walk, add the following after the words } \\
\text { "Contaminant migration": } \\
\text { "by advection and dispersion" }\end{array}$ & \\
\hline
\end{tabular}




\section{NEVADA ENVIRONMENTAL RESTORATION PROJECT DOCUMENT REVIEW SHEET}

Document Title/Number Corrective Action Investigation Plan for the Central Nevada Test

Revision Number Rev. 0

Area Subsurface Sites [Corrective Action Unit No. 443]

Reviewer/Organization_Sigurd Jaunarajs/NDEP

\begin{tabular}{|c|c|c|c|c|}
\hline $\begin{array}{l}10 . \\
\text { Comment } \\
\text { Number/ } \\
\text { Location }\end{array}$ & $\begin{array}{l}11 . \\
\text { Type }^{\mathrm{a}}\end{array}$ & 12. & Comment Response & $\begin{array}{c}14 . \\
\text { Accept }\end{array}$ \\
\hline 13. Page 30 & & $\begin{array}{l}\text { At the end of the first paragraph, it is stated that the contaminant mass will be } \\
\text { divided into } 10,000 \text { particles. Will particle release be simulated as an } \\
\text { instantaneous point source or as a measured, longer term release? Further } \\
\text { explanation and technical justification is warranted. }\end{array}$ & $\begin{array}{l}\text { To address the request for additional information on the release, } \\
\text { the following will be added to the last paragraph in the section } \\
\text { entitled "Model Discussion." The insert will occur before the } \\
\text { existing last sentence. } \\
\text { "The radionuclides produced by the Faultless test are primarily } \\
\text { located within the cavity created by the explosion, though it is } \\
\text { possible that a relatively small proportion of the volatile nuclides } \\
\text { may have been injected outward by the force of the explosion. } \\
\text { Within the cavity, nuclides are distributed according to their } \\
\text { volatility among surface deposits and volume deposits in } \\
\text { nuclear melt glass. Nuclear melt glass dissolution rates may be } \\
\text { calculated using volcanic glass dissolution behavior as an } \\
\text { analog. It is assumed that migration of radionuclides will begin } \\
\text { once the hydraulic head in the cavity recovers to its pre-test } \\
\text { condition. Postshot data confirm that the potentiometric level of } \\
\text { groundwater in the Faultless cavity has not yet reequilibrated. } \\
\text { Once released, some radionuclides will be subject to } \\
\text { retardation reactions." ....go on to existing last sentence }\end{array}$ & \\
\hline
\end{tabular}




\title{
NEVADA ENVIRONMENTAL RESTORATION PROJECT DOCUMENT REVIEW SHEET
}

Document Title/Number Corrective Action Investigation Plan for the Central Nevada Test

Revision Number Rev. 0

\begin{abstract}
Area Subsurface Sites [Corrective Action Unit No. 443]
\end{abstract}
Reviewer/Organization Sigurd Jaunarajs/NDEP

\begin{tabular}{|c|c|c|c|c|}
\hline $\begin{array}{c}10 . \\
\text { Comment } \\
\text { Number/ } \\
\text { Location }\end{array}$ & $\begin{array}{c}11 . \\
\text { Type }^{\text {a }}\end{array}$ & Comment & Comment Response & $\begin{array}{c}14 . \\
\text { Accept }\end{array}$ \\
\hline 14. Page 32 & & $\begin{array}{l}\text { The second paragraph discusses the hydraulic gradient of the water table } \\
\text { which is important for assessing regional flow. Of critical importance, } \\
\text { however, are the hydraulic heads, magnitude and direction of the gradient, } \\
\text { and presence of vertical gradients at the event level and in the immediate } \\
\text { vicinity of UC-1. Knowing the flow direction at the shot level is vital for } \\
\text { predicting potential flow paths and transport rates. This comment is related to } \\
\text { General Comment } 2 \text {. }\end{array}$ & $\begin{array}{l}\text { To address the concern about hydraulic head and the } \\
\text { magnitudes and directions of hydraulic gradients at UC-1, add } \\
\text { the following as a new paragraph after the third paragraph. } \\
\text { "Vertical hydraulic gradients in Hot Creek Valley are indicated } \\
\text { by pre-test head measurements in packer-isolated intervals and } \\
\text { tracer tests in individual boreholes (Dinwiddie and Schroder, } \\
\text { 1971). To the north of Faultless, heads at UCe-17 produce a } \\
\text { gradient of approximately } 0.1 \text { with heads declining with } \\
\text { increasing depth, suggesting potential for vertically downward } \\
\text { flow of groundwater. Conversely, heads at UCe-18 and } \\
\text { UCe-20 to the south of Faultless increase with increasing depth } \\
\text { at a gradient of approximately } 0.02 \text {, suggesting potential for } \\
\text { vertically upward flow of groundwater. At Faultless, which is } \\
\text { located midway between these areas of strong vertical } \\
\text { gradients, pre-test heads at HTH-1 indicate very low vertical } \\
\text { gradients. The head measured in the densely welded tuffs in } \\
\text { the interval of } 1,082.2 \text { to } 1,100.6 \mathrm{~m} \text { (3,501 to } 3,631 \mathrm{ft} \text { ) elevation } \\
\text { was slightly higher than heads measured above and below, } \\
\text { suggesting potential flow from this unit upward and downward } \\
\text { into adjacent units. Static tracer tests confirmed the head } \\
\text { distribution showing upward flow in the borehole above the } \\
\text { welded tuff and downward flow below. More recent thermal } \\
\text { flowmeter measurements also found upward flow in HTH-1 (an } \\
\text { obstruction prevented measurements in the bottom portion of } \\
\text { the borehole), but at much lower rates (Mihevic et al., } 1996 \text { ). } \\
\text { The Faultless test was detonated approximately } 200 \mathrm{~m}(656 \mathrm{ft} \text { ) } \\
\text { below the bottom of the welded tuff interval noted at HTH-1, at } \\
\text { an elevation of } 885 \mathrm{~m} \text { ( } 2,903 \mathrm{ft} \text { ) above mean sea level. No } \\
\text { direct information exists about vertical hydraulic gradients in the } \\
\text { Faultless emplacement hole, though pre-test flow conditions are } \\
\text { likely to be similar to conditions at HTH-1, which is located } \\
\text { approximately } 900 \mathrm{~m} \text { ( } 2,953 \mathrm{ft} \text { ) to the southeast. }\end{array}$ & \\
\hline
\end{tabular}




\section{NEVADA ENVIRONMENTAL RESTORATION PROJECT DOCUMENT REVIEW SHEET}

Document Title/Number Corrective Action Investigation Plan for the Central Nevada Test

Revision Number Rev. 0

Area Subsurface Sites [Corrective Action Unit No. 443]

Reviewer/Organization_Sigurd Jaunarajs/NDEP

\begin{tabular}{|c|c|c|c|c|}
\hline $\begin{array}{c}10 . \\
\text { Comment } \\
\text { Number/ } \\
\text { Location }\end{array}$ & $\begin{array}{c}11 . \\
\text { Type }^{\text {a }}\end{array}$ & Comment & Comment Response & $\begin{array}{c}14 . \\
\text { Accep }\end{array}$ \\
\hline 15. Page 33 & & $\begin{array}{l}\text { Section ' } 5.1 .3 \text { - Validate Model Results Using Existing/New Data' should } \\
\text { cover both calibration and validation - see General Comment } 3 \text {. More detail } \\
\text { is needed in the remarks on the calibration procedure. Have calibration } \\
\text { targets and acceptable residuals (from the ASTM document referred to in this } \\
\text { section) been established yet? Will an automated calibration method be } \\
\text { used? Will a sensitivity analysis be performed and how will the problem of } \\
\text { uniqueness be addressed? This section should provide more than just a } \\
\text { reference to a guidance document. }\end{array}$ & $\begin{array}{l}\text { As part of the concern about lack of detail in the calibration } \\
\text { section, move the first three paragraphs of Section } 5.1 .3 \\
\text { (including the bullets) to the beginning of the "Data Availability" } \\
\text { section under Section 5.1.2. } \\
\text { To address the concern about lack of detail in the calibration } \\
\text { section, Section } 5.1 .3 \text { was replaced. }\end{array}$ & \\
\hline 16. Page 35 & & $\begin{array}{l}\text { Section ' } 5.1 .5 \text { - Determination of Model Acceptability' does not discuss how } \\
\text { DOE will determine model acceptability. This section requires some specific } \\
\text { criteria upon which the model will be evaluated. It should relate directly to the } \\
\text { adequacy of existing model input data and how data sufficiency will be } \\
\text { considered in light of model results. These criteria should be presented in } \\
\text { conjunction with a discussion on how the scientific merit of the strategy will be } \\
\text { judge and how questions about collecting additional data will be addressed, } \\
\text { should that become necessary as put fourth in the process flow diagram in } \\
\text { Figure } 1-1 \text {. Items depicted on the lower right side of the shaded Corrective } \\
\text { Action Investigation portion of Figure } 1-1 \text { should be covered somewhere in } \\
\text { this plan. }\end{array}$ & $\begin{array}{l}\text { Section } 5.1 .5 \text { was deleted as it is not required by the FFACO } \\
\text { outline and the information requested will be covered in } \\
\text { Sections 5.1.1 through 5.1.4. }\end{array}$ & \\
\hline
\end{tabular}

${ }^{\mathrm{a} C o m m e n t ~ T y p e s:} \mathrm{M}=$ Mandatory $\mathrm{S}=$ Suggested.

Return Document Review Sheets to DOE/NV Environmental Restoration Division, Attn: QAC, M/S 505 


\section{NEVADA ENVIRONMENTAL RESTORATION PROJECT DOCUMENT REVIEW SHEET}

1. Document Title/Number Corrective Action Investigation Plan for the Central Nevada Test $2 . \quad$ Document Date February 1998 Area Subsurface Sites [Corrective Action Unit No. 443] Appendix A - DQOs for UC-1

3. Revision Number_Rev. 0

5. Responsible DOE/NV ERP Subproject Mgr. Monica L. Sanchez

7. Review Criteria NDEP review of document

8. Reviewer/Organization/Phone No. Clem Goewert/NDEP
4. Originator/Organization DOE/IT

6. Date Comments Due

9. Reviewer's Signature

\begin{tabular}{|c|c|c|c|c|}
\hline $\begin{array}{l}10 . \\
\text { Comment } \\
\text { Number/ } \\
\text { Location }\end{array}$ & $\begin{array}{l}11 . \\
\text { Type }^{\mathrm{a}}\end{array}$ & Comment & Comment Response & $\begin{array}{l}14 . \\
\text { Accept }\end{array}$ \\
\hline $\begin{array}{l}\text { 1. Page } 49 \\
\text { Item I-B6. }\end{array}$ & & $\begin{array}{l}\text { The only receptor identified is the human receptor. Other environmental } \\
\text { receptors should be discussed, even if they have been eliminated from } \\
\text { consideration. }\end{array}$ & $\begin{array}{l}\text { A second sentence was added which reads "The only known } \\
\text { environmental receptor is the groundwater in the vicinity of the shot } \\
\text { cavity." }\end{array}$ & \\
\hline $\begin{array}{l}\text { 2. Page } 49 \\
\text { Item I-C1. }\end{array}$ & & This section should briefly describe potential exposure pathways. & $\begin{array}{l}\text { The section was changed to read "migration of contaminated } \\
\text { groundwater up a borehole during drilling, development, and usage } \\
\text { of the groundwater resource." }\end{array}$ & \\
\hline $\begin{array}{l}\text { 3. Page } 49 \\
\text { Item I-C3. }\end{array}$ & & $\begin{array}{l}\text { This section should describe applicable or relevant and appropriate requirements } \\
\text { (ARARs) or preliminary remediation goals. If no ARARs or preliminary } \\
\text { remediation goals are being considered, then simply state that. } \\
\text { The second paragraph describes the boundary restrictions at a dose rate. As has } \\
\text { been discussed, the boundary restrictions/control will be based upon the drinking } \\
\text { water standards. }\end{array}$ & $\begin{array}{l}\text { The first paragraph was changed to read "There are no applicable } \\
\text { or relevant and appropriate requirements other than the FFACO." } \\
50 \mathrm{mrem} / \mathrm{yr} \text { was changed to } 4 \mathrm{mrem} / \mathrm{yr} \text {. }\end{array}$ & \\
\hline $\begin{array}{l}\text { 4. Page } 49 \\
\text { Item I-C4. }\end{array}$ & & $\begin{array}{l}\text { The "exposure scenario" refers to the exposure of humans during the drilling, } \\
\text { development, and usage of the groundwater resource. }\end{array}$ & $\begin{array}{l}\text { The section was changed to read "The exposure of humans during } \\
\text { drilling, development, and usage of the groundwater resources." }\end{array}$ & \\
\hline $\begin{array}{l}\text { 5. Page } 50 \\
\text { Item I-D2. }\end{array}$ & & Update the time constraints to reflect new CAIP deadlines. & $\begin{array}{l}\text { Section changed to read "There are no current deadlines for this } \\
\text { CAIP. }\end{array}$ & \\
\hline $\begin{array}{l}\text { 6. Page } 50 \\
\text { Item I-E }\end{array}$ & & $\begin{array}{l}\text { The problem description should include two important points. The first is that } \\
\text { groundwater was undoubtedly contaminated by the test, since the device was } \\
\text { placed below the water table. The second concerns the impact caused by } \\
\text { migration of contaminants. Questions concerning the extent of the radionuclides } \\
\text { exceeding the drinking water standards and the nature of those radionuclides } \\
\text { should be coupled with the problem of defining a contaminant boundary. Also } \\
\text { remember that per the FFACO, a contaminant boundary is composed of both the } \\
\text { perimeter defining the areal extent of contamination and a lower } \\
\text { hydrostratigraphic unit boundary. Rewrite this section into a more concise } \\
\text { description of the problem to be resolved. }\end{array}$ & $\begin{array}{l}\text { This was the agreed to wording at the DQO meeting held on March } \\
19 \text { and } 20,1997 \text { which was attended by representatives from DOE, } \\
\text { contractors, and three representatives from NDEP. }\end{array}$ & \\
\hline
\end{tabular}




\section{NEVADA ENVIRONMENTAL RESTORATION PROJECT DOCUMENT REVIEW SHEET}

Document Title/Number Corrective Action Investigation Plan for the Central Nevada Test

Revision Number Rev. 0

Area Subsurface Sites [Corrective Action Unit No. 443]

Reviewer/Organization_Clem Goewert/NDEP

\begin{tabular}{|c|c|c|c|c|}
\hline $\begin{array}{l}10 . \\
\text { Comment } \\
\text { Number/ } \\
\text { Location }\end{array}$ & $\begin{array}{l}11 . \\
\text { Type }^{a}\end{array}$ & Comment & Comment Response & $\begin{array}{l}14 . \\
\text { Accept }\end{array}$ \\
\hline $\begin{array}{l}\text { 7. Page } 50 \\
\text { II-A }\end{array}$ & & $\begin{array}{l}\text { The principal study question has not been clearly delineated. Certainly, a } \\
\text { transport model can define a contaminant boundary using existing data. } \\
\text { The principal question is whether a contaminant boundary can be established } \\
\text { with sufficient confidence and scientific validity such that an acceptable } \\
\text { regulatory compliance boundary can then be agreed upon. }\end{array}$ & $\begin{array}{l}\text { The section was changed to read "Can a contaminant boundary be } \\
\text { established with sufficient confidence and scientific validity such } \\
\text { that an acceptable regulatory compliance boundary can be agreed } \\
\text { upon." }\end{array}$ & \\
\hline $\begin{array}{l}\text { 8. Page } 50 \\
\text { C } 1 .\end{array}$ & & $\begin{array}{l}\text { These prioritized decisions should be stated more completely and in a clear } \\
\text { manner such that a Corrective Action Decision can be made. }\end{array}$ & $\begin{array}{l}\text { The section was changed as follows: } \\
\text { " a. Are adequate data available to develop the CNTA } \\
\text { groundwater flow model so an acceptable contaminant boundary } \\
\text { can be defined? } \\
\text { b. After initial modeling is completed is there enough confidence } \\
\text { and validity in the contaminant boundary to be acceptable to all } \\
\text { participants? } \\
\text { c. Will the acquisition of additional data be needed to better } \\
\text { constrain the model and the contaminant boundary?" }\end{array}$ & \\
\hline $\begin{array}{l}\text { 9. Page } 50 \\
\text { C } 2 \text {. }\end{array}$ & & $\begin{array}{l}\text { Determine the logical Sequence of Actions. This was addressed by saying } \\
\text { "follow the flow chart in the FFACO, Figure 3-4." The diagram is or a general } \\
\text { UGTA CAU, however, the DQO is supposed to be tailored for each CAU. A } \\
\text { CAU-specific sequence of actions should be outlined. }\end{array}$ & $\begin{array}{l}\text { The basic flow path is the same whether it is an UGTA CAU or an } \\
\text { Off-Sites CAU so the FFACO flow chart is applicable, the strategy } \\
\text { is the same. }\end{array}$ & \\
\hline $\begin{array}{l}\text { 10. Page } 51 \\
\text { III A } 1 .\end{array}$ & & $\begin{array}{l}\text { Item a. Does "scale adequacy" refer to the scale of the modeling nodes or the } \\
\text { area to be modeled or both? This requires further explanation. }\end{array}$ & $\begin{array}{l}\text { Scale adequacy refers to the size of the modes relative to the size } \\
\text { of the area to be modeled. The text was changed to read "Scale } \\
\text { adequacy for the modeling nodes" }\end{array}$ & \\
\hline $\begin{array}{l}\text { 11. Page } 51 \\
\text { III C. }\end{array}$ & & $\begin{array}{l}\text { The basis for establishing contaminant-specific action level(s) for radionuclides } \\
\text { should be the drinking water standards. }\end{array}$ & $50 \mathrm{mrem} / \mathrm{yr}$ was changed to $4 \mathrm{mrem} / \mathrm{yr}$ & \\
\hline $\begin{array}{l}\text { 12. Page } 51 \\
\text { III C. }\end{array}$ & & $\begin{array}{l}\text { "Chemical" is listed as a basis item for establishing action levels. The phrase } \\
\text { "chemical contaminants" is perhaps more appropriate here. }\end{array}$ & It was changed to "chemical contaminants" & \\
\hline
\end{tabular}




\section{NEVADA ENVIRONMENTAL RESTORATION PROJECT DOCUMENT REVIEW SHEET}

Document Title/Number Corrective Action Investigation Plan for the Central Nevada Test

Revision Number Rev. 0

Area Subsurface Sites [Corrective Action Unit No. 443]

Reviewer/Organization_Clem Goewert/NDEP

\begin{tabular}{|c|c|c|c|c|}
\hline $\begin{array}{l}10 . \\
\text { Comment } \\
\text { Number/ } \\
\text { Location }\end{array}$ & $\begin{array}{l}11 . \\
\text { Type }^{\mathrm{a}}\end{array}$ & Comment & Comment Response & $\begin{array}{l}14 . \\
\text { Accept }\end{array}$ \\
\hline $\begin{array}{l}\text { 13. Page } 52 \\
\text { IV A. } 1 .\end{array}$ & & $\begin{array}{l}\text { The corrective action plan and the Data Quality Objectives (DQOs) do not appear } \\
\text { to be in agreement with one another in regards to the area to be modeled. The } \\
\text { DQOs state that the modeling area will be the land withdrawal area. The CAI } \\
\text { states that the modeling will be based upon the hydraulic conditions. These are } \\
\text { likely no the same and the discrepancy should be rectified. }\end{array}$ & $\begin{array}{l}\text { The one-square mile area given on page } 52 \text { of the DQOs is the } \\
\text { "geographic area within which all decisions must apply", and } \\
\text { coincides with the DOE land withdrawal boundary, not the model } \\
\text { domain. The model study area given on page } 26 \text { identifies a large } \\
\text { portion of Hot Creek Valley that will be used as a source of data for } \\
\text { the modeling. As stated in the second paragraph of } 5.1 .2, \text { the } \\
\text { precise model boundaries will not be specified until preliminary } \\
\text { data analysis occurs, but is unlikely to encompass the large region } \\
\text { used for data. As no actual model dimensions are proposed at this } \\
\text { time, no problem with consistency in the document can be } \\
\text { identified. }\end{array}$ & \\
\hline $\begin{array}{l}\text { 14. Page } 52 \\
\text { IV B. }\end{array}$ & & $\begin{array}{l}\text { The temporal boundary of the decision to which the study apply is simply given } \\
\text { as } 1,000 \text { years. Provide some justification for the } 1,000 \text { year time frame. }\end{array}$ & $\begin{array}{l}\text { This was the agreed to time frame at the DQO meeting held on } \\
\text { March } 19 \text { and } 20,1997 \text {. It is a reasonable length of time for a } \\
\text { model to cover. }\end{array}$ & \\
\hline $\begin{array}{l}\text { 15. Page } 52 \\
\text { IV C. }\end{array}$ & & $\begin{array}{l}\text { Classification is given as a practical constraint on data collection. How would } \\
\text { classification constrain data collection? Wouldn't classification mainly constrain } \\
\text { the analysis, use, and discussion of the data and not the collection? }\end{array}$ & $\begin{array}{l}\text { Data collection is more than going in the field and collecting } \\
\text { samples, it can include other facets such as looking at the } \\
\text { classified source term for the shot so classification can be a } \\
\text { constraint. }\end{array}$ & \\
\hline $\begin{array}{l}\text { 16. Page } 52 \\
\text { V B. }\end{array}$ & & $\begin{array}{l}\text { The action level for radionuclides is given as } 50 \mathrm{mrem} / \mathrm{yr} \text {. The action levels for } \\
\text { radionuclide are Nevada's drinking water standards. }\end{array}$ & $50 \mathrm{mrem} / \mathrm{yr}$ was changed to $4 \mathrm{mrem} / \mathrm{yr}$ & \\
\hline $\begin{array}{l}\text { 17. Page } 52 \\
\text { V C. }\end{array}$ & & The decision needs to be reevaluated based upon previous comments. & $50 \mathrm{mrem} / \mathrm{yr}$ was changed to $4 \mathrm{mrem} / \mathrm{yr}$ & \\
\hline $\begin{array}{l}\text { 18. Page } 53 \\
\text { VI }\end{array}$ & & $\begin{array}{l}\text { The acceptable limits on the decision errors that are given are for the large scale } \\
\text { UGTA CAU's on the Nevada Test Site. These limits should have been } \\
\text { readdressed for the specific conditions of the UC-1 event. This location has } \\
\text { specific needs, requirements, and conditions. }\end{array}$ & $\begin{array}{l}\text { This was the agreed to wording at the DQO meeting held on March } \\
19 \text { and } 20,1997 \text { which was attended by representatives from DOE, } \\
\text { contractors, and three representatives from NDEP. }\end{array}$ & \\
\hline
\end{tabular}

${ }^{\mathrm{a}}$ Comment Types: $\mathrm{M}=$ Mandatory, $\mathrm{S}=$ Suggested .

Return Document Review Sheets to DOE/NV Environmental Restoration Division, Attn: QAC, M/S 505 


\section{NEVADA ENVIRONMENTAL RESTORATION PROJECT DOCUMENT REVIEW SHEET}

1. Document Title/Number Corrective Action Investigation Plan for the Central Nevada Test Area Subsurface Sites [Corrective Action Unit No. 443] Appendix A - DQOs for UC-4

3. Revision Number Rev. 0

2. Document Date February 1998

4. Originator/Organization DOE/IT

5. Responsible DOE/NV ERP Subproject Mgr. Monica L. Sanchez

6. Date Comments Due

7. Review Criteria NDEP review of document

8. Reviewer/Organization/Phone No. Clem Goewert/NDEP

9. Reviewer's Signature

\begin{tabular}{|c|c|c|c|c|}
\hline $\begin{array}{c}10 . \\
\text { Comment } \\
\text { Number/ } \\
\text { Location }\end{array}$ & $\begin{array}{l}11 . \\
\text { Type }\end{array}$ & Comment & Comment Response & $\begin{array}{l}14 . \\
\text { Accept }\end{array}$ \\
\hline $\begin{array}{l}\text { 1. Page } 55 \\
\text { I D2 }\end{array}$ & & $\begin{array}{l}\text { The Defined relevant time constraints are given as the review date. The } \\
\text { time constraints are the FFACO Deadlines. }\end{array}$ & $\begin{array}{l}\text { There are no current deadlines for this CAIP in the FFACO so } \\
\text { the text was changed to read, "There are no current deadlines } \\
\text { for this CAIP." }\end{array}$ & \\
\hline $\begin{array}{l}\text { 2. Page } 56 \\
\text { II B 1c. }\end{array}$ & & $\begin{array}{l}\text { Plugging the well may not be an acceptable option if significant migration is } \\
\text { occurring. }\end{array}$ & $\begin{array}{l}\text { This is a true statement, however, until the modeling is } \\
\text { completed so know what the situation is there is no point in } \\
\text { making alternate plans. }\end{array}$ & \\
\hline $\begin{array}{l}\text { 18. Page } 59 \\
\text { VII }\end{array}$ & & $\begin{array}{l}\text { The most optimized design for this CAS would be to analyze data from the } \\
\text { mud pit closure to determine if contaminants are present in the drilling fluids. } \\
\text { If contaminants are present then go through the a through } \mathrm{k} \text { analysis. }\end{array}$ & $\begin{array}{l}\text { It is our belief that Section VII meets the objective of your } \\
\text { comment. }\end{array}$ & \\
\hline
\end{tabular}

a Comment Types: $M=$ Mandatory, $S=$ Suggested.

Return Document Review Sheets to DOE/NV Environmental Restoration Division, Attn: QAC, M/S 505 


\section{Distribution List}

\section{$\underline{\text { Copies }}$}

Paul J. Liebendorfer

2 (Controlled)

Bureau of Federal Facilities

Division of Environmental Protection

333 W. Nye Lane, Room 138

Carson City, NV 89706-0851

Supervisor

1 (Controlled)

Bureau of Federal Facilities

Division of Environmental Protection

555 E. Washington, Suite 4300

Las Vegas, NV 89101

Sabrina D. Lawrence

DOE/Nevada Operations Office

1 (Controlled)

Environmental Restoration Division

P.O. Box 98518, M/S 505

Las Vegas, NV 89193-8518

Rosa Silver

3 (Controlled)

IT Corporation

1 (Uncontrolled)

P.O. Box 98521, M/S 439

Las Vegas, NV 89493-8521

Monica L. Sanchez

1 (Uncontrolled)

DOE/Nevada Operations Office

Environmental Restoration Division

P.O. Box 98518, M/S 505

Las Vegas, NV 89193-8518

Peter A. Sanders

1 (Uncontrolled)

DOE/Nevada Operations Office

Environmental Restoration Division

P.O. Box 98518, M/S 505

Las Vegas, NV 89193-8518

Jenny Chapman

2 (Uncontrolled)

Desert Research Institute

P.O. Box 19040, M/S 433

Las Vegas, NV 89132

David D. Madsen

1 (Uncontrolled)

Bechtel Nevada

P.O. Box 98531, M/S NTS306

Las Vegas, NV 89193-8521 


\section{$\underline{\text { Copies }}$}

Paul Gretsky

5 (Uncontrolled)

IT Corporation

P.O. Box 98521, M/S 439

Las Vegas, NV 89493-8521

U.S. Department of Energy

1 (Uncontrolled)

Nevada Operations Office

Technical Information Resource Center

P.O. Box 98518

Las Vegas, NV 89193-8518

U.S. Department of Energy

1 (Controlled)

Nevada Operations Office

1 (Uncontrolled)

Public Reading Facility

P.O. Box 98521

Las Vegas, NV 89193-8521

U.S. Department of Energy

Office of Scientific and Technical Information

Electronic Copy

P.O. Box 62

Oak Ridge, TN 37831-0062

IT Corporation Central Files

1 (Uncontrolled)

IT Corporation

P.O. Box 98521, M/S 439

Las Vegas, NV 89493-8521 